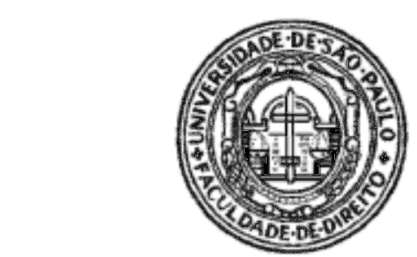

UNiVERSidade de São Paulo

FACULDADE DE DiREITO

Departamento de Filosofia e TeOria Geral do Direito

Dissertação de Mestrado

\title{
A Emergência do Real Quotidiano
}

Dois Exemplos de Delimitação do Público e do Privado no Direito Brasileiro

Dissertação de mestrado apresentada ao Departamento de Filosofia e Teoria Geral do Direito sob orientação do Professor Titular Tercio Sampaio Ferraz Jr.

Candidato: Gabriel Nascimento Pinto

São Paulo

2012 


\section{A EMERGÊNCIA do REAL QUOTIDIANo \\ DoIs EXEMPlos DE DELIMITAÇÃo Do PÚBliCO E DO PRIVADO NO DIREITO BRASILEIRO}

\section{Sumário}

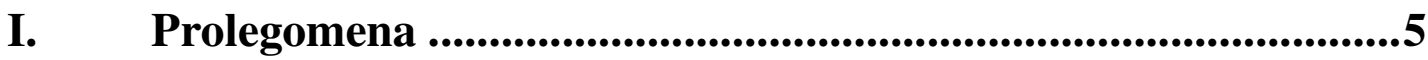

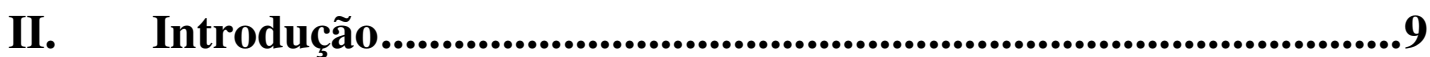

III. Excurso: Uma Breve Passagem sobre o Direito em Mimesis ..31

IV. A Desapropriação da Várzea do Rio Pinheiros..........................44

V. A Desapropriação do Metrô de Santana ......................................62

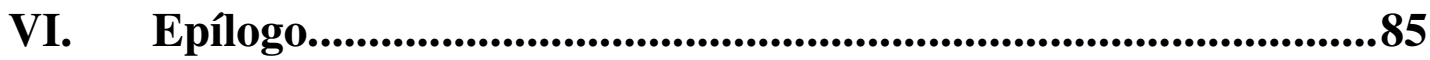

VII. Bibliografia ................................................................................88 


\section{Resumo}

O presente trabalho parte da concepção de que o direito constitui um medium de exposição da realidade, em analogia, ainda que distante, com as reflexões sobre a literatura do filólogo alemão Erich Auerbach. Desse ponto de partida, segue-se para a identificação de um tema específico em que essa forma de exposição jurídica poderia, com mais clareza, ser analisada. São então enfocados os conflitos e debates ligados às desapropriações por zona realizadas no século XX na cidade de São Paulo e que estiveram fortemente relacionadas com os movimentos de estruturação e crescimento da metrópole. Da observação das densidades históricas e jurídicas do projeto de saneamento do Rio Pinheiros e da reurbanização do Metrô de Santana, será possível identificar, pelo contraste existente entre eles, uma alteração na forma como, face a um mesmo instituto jurídico - a desapropriação - variou o modo de conceber o público e o privado, suas funções e limites. Se no começo do século XX foi unanimemente aceito o exercício por uma empresa privada do direito de expropriação de terras particulares ao longo do Rio Pinheiros, as visões se alterariam de tal forma que ato semelhante, nos anos de 1970, levaria a uma profunda divisão do Supremo Tribunal Federal quanto à legalidade da medida.

A hipótese pesquisada é a de que a jurisprudência reflete e medeia movimentos mais amplos da sociedade e, por isso, tornou-se mais permeável à representação de outros interesses e alargou seu espectro de exposição da realidade, o que se busca mostrar no epílogo com o exemplo da reintegração de posse de uma favela em São Paulo, em que a racionalidade jurídica mais estrita cedeu lugar a uma representação mais direta de um conflito urbano.

Palavras-Chave: Teoria Literária - Auerbach - Desapropriação - Direito Administrativo Teoria do Direito - São Paulo 


\begin{abstract}
The work departs from the conception that the law is a medium of reality's representation, in analogy, perhaps distant, with the work on literature of the German philologist Erich Auerbach. Taking this as a starting point, what follows identifies a specific subject in law practice in which the law's representation of reality could be clearly analyzed: the conflicts and debates arising from excess condemnation procedures in São Paulo along the $20^{\text {th }}$ century and their relationship to the growth and restructuring of the city as a metropolis. Its aim is to observe legal and historical densities related to urban projects of intervention in the Pinheiros River and the urbanization for the construction of the Santana subway station. In both cases shall be identified, in their contrast, how the conceptions of private and public changed along the years. Even if the analysis keeps centered on the same legal instrument - takings procedures - it shall nevertheless become clear that conceptions of public and private spheres have undergone deep changes, as well as the functions and roles that each of these spheres plays in Brazilian society. If in the beginning of the $20^{\text {th }}$ century the exercise of excess condemnation rights by a private company was unanimously accepted, the legal mentalities would significantly change so that the same procedure would create a deep dissention within Brazilian Supreme Court Justices when they had to decide on its legality. The research hypothesis is that judicial decisions became more open to the representation of a legal reality containing the interests of different people and groups, what shall be shown in the conclusion by the analysis of a legal action undertaken against a slum in São Paulo at the end of $20^{\text {th }}$ century in São Paulo.
\end{abstract}

Key Words: Literary Theory - Auerbach - Takings - Excess Condemnation Administrative Law - Legal Theory - São Paulo 
Lorsque vous tournez les grandes pages roides d'un infolio, les feuilles jaunies d'un manuscript, bref un poème, un code, un symbole de foi, quelle est votre première remarque?

C'est qu'il ne s'est point fait tout seul.

H. Taine

Histoire de la Littérature Anglaise

Introduction, tome I, p. VI.

(...) nunca tiveram a obsessão da ordem senão como princípio abstrato, nem da liberdade senão como capricho.

A. Candido

A Dialética da Malandragem

\section{Prolegomena}

A ideia condutora das linhas que seguem surgiu da leitura de um livro de João Cezar de Castro Rocha, Literatura e Cordialidade, originalmente sua tese de Doutoramento. Àquela época, estava em busca de um modo de estruturação do argumento, um fio condutor. Estava também a ler os cinco volumes dos contos de Machado de Assis, cujo organizador é o próprio João Cezar, e cujos volumes contam todos com uma introdução analítica e contextual do próprio João Cezar. É preciso confessar, o programa de João Cezar no seu Literatura $e$ Cordialidade - o intuito que pretendia com sua tese - produziu forte impressão à época e, por esse motivo, acabou alçado a chave mestra de interpretação para o problema do presente trabalho. O que paradoxalmente mais impressiona no seguimento da leitura de João Cezar, contudo, é o contraste entre a arguta ideia e a sua concretização ao longo do livro, que deixa a desejar, para alguns críticos, com os quais, sinceramente, podemos concordar sem lhe ser totalmente injusto.

Isso, porém, não retira de todo o valor à ideia perspicaz, da qual, para o bem ou para o mal, o que vem abaixo é tributário. Verdade é que, no que tange a Literatura e Cordialidade, há uma forte tensão entre andamento ulterior, o texto como um todo, e a fina percepção sintética que se denota no título, introdução e proposta do livro, que é, como diz o subtítulo, uma investigação sobre o público e o privado na cultura brasileira.

Definitivamente, formular que a delimitação - ou confusão - do público e do privado constituiria uma realidade exposta (dargestellte Wirklichkeit) de conflito - além de um tema 
recorrente na literatura brasileira - é uma grande ideia, e vale por si, ainda que a estruturação do argumento apresente algumas falhas ou tenha execução aquém do programa. Para esse último caso pode-se, com efeito, dizer que dificilmente alguma execução, por mais genial que fosse, estaria à altura de um programa tão amplo como a tal pesquisa do público e do privado na cultura brasileira. Isto porque dificilmente alguma empreitada teórica seria capaz de abarcar, sinteticamente, uma realidade histórica e social tão multifacetada como a constituição e as relações entre esses dois âmbitos. A rigor, seria possível questionar até mesmo a formação desses âmbitos na medida em que as tais relações não seriam absolutamente naturalmente inatas e historicamente perenes, dois campos inerentes à sociedade, mas sim seriam elemento de um contexto histórico específico. Dificilmente se poderia dizer que publicidade e privacidade, e suas confrontações, formam um substrato inerente a qualquer sociedade. Mesmo a recorrência com que se aponta serem as relações entre essas esferas um dos problemas centrais da sociedade brasileira, também esse enunciado é localizado historicamente, ainda que possa soar de tal forma convincente e geral, possivelmente por sua reiteração constante como chave de compreensão de alguns problemas do social e do político no Brasil.

Nesse sentido, melhor seria ver as tentativas de aproximação ao problema, incluída aí a de João Cezar, como um olhar sempre parcial, incompleto, em direção à apreensão das relações público/privado na cultura brasileira. Pretender a completude em tal empreitada seria um meio caminho para a constante deficiência do argumento em virtude da imensa pretensão e extensão do programa.

Por isso, buscar em João Cezar a totalidade pode ser uma chave de leitura equivocada, de melhor valia seria ver em seu propósito antes uma estrutura aberta, uma sugestão, que ensejaria outros desenvolvimentos. Pois é nessa toada, com efeito, que vão as linhas abaixo, tem-se aqui um pequeno desenvolvimento daquela ideia ampla, que pela sua complexidade, poderá, novamente, não encontrar alguém à sua altura para lhe dar o devido desenvolvimento.

Isso não exclui, porém, a tentativa. E se, como o foi para João Cezar, for também este um pequeno erro para uma miríade de acertos posteriores, parece, então, valer a pena capitalizar o erro em acertos futuros de percepção, ainda que nada o possa garantir.

A menção a João Cezar de Castro Rocha não é circunstancial, mas sim constitui um acerto de contas com a genealogia do trabalho, bem como com as razões e momentos de seu 
surgimento. É certo que ser objeto de uma arqueologia, principalmente por não ser este um dos grandes discursos, é privilégio de uns poucos, que atraem algum interesse, por isso mais acertado será empreender uma auto-arqueologia, ainda que sumária, para aclarar um pouco da gênese do trabalho.

O próprio Foucault costumava expor que origens são frequentemente mais espúrias do que se costuma admitir. É certamente mais confortável resignificar a tradição do nosso romantismo na origem José de Alencar do que aceitar que, à sua época, notável foi Gonçalves de Magalhães, tendo o Imperador Pedro II defendido arduamente seu Confederação dos Tamoios, romance hoje tido por pífio. É realmente complexo fazer sentido sério do próprio passado, explicar de que modo uma sociedade teve uma percepção equivocada dos produtos de seu tempo. Mais simples seria confortavelmente reescrever tudo aquilo, apagando em parte a origem espúria (Ursprung) em face de uma agradável invenção (Erfindung) da tradição, que estará mais em consonância com os pensares contemporâneos ${ }^{1}$. A origem, entretanto, deixa marcas indeléveis que podem ser redescobertas e, dessa forma, evidenciar boa parte dos primórdios da invenção, que, aliás, dizem muito sobre os narradores da invenção e suas concepções.

Pois bem, como dificilmente deste escrito arqueologia alguma se fará, melhor evidenciar, desde logo, suas origens ao invés de promover a sua invenção honrosa. E, como foi mencionado, a origem remonta a João Cezar e à sua ideia. E se fosse possível optar pela invenção, certamente seria Erich Auerbach a ideia fonte de tudo, mas cronologicamente ele foi posterior. Auerbach, contudo, constitui um forte contraponto à forma de exposição desse texto, contrapõe-se, de alguma maneira, a João Cezar. Se esse é grandiloquente e forte em sua introdução e esboça o projeto do que poderia ser uma obra seminal, de grande poder explicativo, cuja execução, pode-se dizer, deixa a desejar; Auerbach, por sua vez, pouco explicou de seu projeto e não inseriu em introdução uma intenção ampla e ambiciosa, ainda que seu subtítulo seja igualmente forte: a realidade exposta na literatura ocidental. É, aliás, conhecida a anedota de que Auerbach nega uma introdução a um editor para a edição israelense de Mimesis por considerar que os três capítulos iniciais, de forma escorreita e pouco

\footnotetext{
${ }^{1}$ Veja-se, adicionalmente, o comentário de Antonio Candido sobre literatura e nacionalismo no Brasil: "Esta ânsia de diferenciação integral de uma jovem nação explica o incremento que teve no século XIX o desejo de inventar um passado que já fosse nacional, marcando desde cedo a diferença em relação à mãe pátria." CANDIDO, Antonio. "Literatura de dois gumes" in A Educação pela Noite. Rio de Janeiro: Ouro sobre Azul, 2006, p. 211.
} 
explícita, denotam seu programa e amplitude de pretensões, não sendo necessário qualquer complemento, tampouco um que situasse teoricamente o livro ${ }^{2}$. Nos pontos em que João Cezar explicita, Auerbach é indireto e pouco claro, mas paradoxalmente mais preciso e profundo, com o que, provavelmente, o próprio João Cezar concordaria.

É com seu sermo humilis - acompanho nesse ponto a interpretação de Leopoldo Waizbort $^{3}$ - que Auerbach cria uma obra de grandes proporções cuja amplitude apenas nos daremos conta depois da segunda ou terceira leitura integral, pois trata-se de uma leitura das mais orgânicas em que os capítulos encontram-se dispostos de uma forma concatenada e organizada a partir de uma concepção mestra de estrutura aberta e organicidade ${ }^{4}$.

É, enfim, no grande arco improvável que liga um estudante de direito interessado em questões urbanísticas à boa mal desenvolvida ideia de João Cezar e à humilde grande obra de Auerbach que se inscrevem estas linhas. Essas são suas origens.

\footnotetext{
2 "Mimesis in Palästina. Zwei Briefe von Erich Auerbach und Martin Buber" in Trajekte, v. 2, 2001, pp. 4-7.

${ }^{3}$ WAIZBORT, Leopoldo. A Passagem do três ao um: crítica literária, sociologia, filologia. São Paulo: Cosac Naify, 2007, p. 290.

${ }^{4}$ Sobre a organicidade: "A inserção de um capítulo [XI, sobre Cervantes] em meio ao livro indica a complexa relação de todo e parte que o articula". WAIZBORT, op. cit., p. 11.
} 


\section{Introdução}

Esta empreitada foge um pouco ao enfoque que se poderia verter sobre questões jurídicas. Localiza-se, de alguma maneira, num meio de caminho. Se seu ponto de partida é propriamente jurídico - são afinal decisões de tribunais que serão analisadas - o olhar que lhes será vertido destoa ligeiramente do olhar próprio ao jurista. Para fazer justiça à tradição, chame-se esse olhar de zetético. Mas, é importante notar, a referência seria a uma zetética de extração particular, sem que isso implique distinção qualitativa, basta dizer que ela é histórica $^{5}$. Posto de maneira mais clara, o foco recai sobre dois momentos da apreensão jurídica da realidade, separados entre si no século XX por algumas décadas. Trata-se de dois casos, dois Recursos Extraordinários, levados à apreciação de uma mesma instituição, o Supremo Tribunal Federal. Este se guarda a mesma denominação, seria, todavia, precipitado promover uma total equiparação entre o Supremo do primeiro caso e aquele do segundo. Seria, no mínimo, em grande medida, uma igualdade imperfeita, pois não apenas os anos, mas também uma série de transformações sociais e jurídicas profundas, separam aquelas duas ocasiões nas quais uma certa faceta dos conflitos urbanos em São Paulo foi juridicamente exposta.

Em verdade, será preciso, desde logo, situar o ponto a partir do qual se enfocará esses momentos. São dois casos de desapropriação por zona, um cujos fatos remontam ao final da década de 1920 e à margem do Rio Pinheiros. A desapropriação foi levada a cabo por uma conjuntura que uniu o governo do Estado de São Paulo e a Brazilian Traction, Light \& Power Company Limited, que era àquela altura concessionária (se não for anacronismo chamá-la assim), dentre outros serviços ${ }^{6}$, da produção de energia elétrica no município de São Paulo. A

\footnotetext{
${ }^{5}$ Posição devida à influência que Auerbach desempenha sobre o presente trabalho. "I, on the contrary, am concerned with something more general, which I shall have the occasion to describe later on. My purpose is always to write history. Consequently I never approach a text as an isolated phenomenon; I address a question to it, and my question, not the text, is my primary point of departure." AUERBACH, Erich. "Introduction: Purpose and Method" in Literary Language and Its Public in Late Latin Antiquity and in the Middle Ages. New York: Pantheon Books, 1965, p. 20.

${ }^{6}$ A companhia canadense atuava também nos transporte municipal por meio de bondes, atividade que, aliás, grande sinergia possuía com a produção de energia. Cf. Lei Estadual n. 2.109 de 29 de dezembro de 1925: "Artigo 1." - A empreza «The São Paulo Tramway, Light and Power Company Limited», sociedade anonyma incorporada no Dominio do Canadá, e autorizada a funcionar no Brasil pelo decreto 3349, de 17 de Julho de 1899, concessionaria do serviço de viação urbana e fornecimento de energia electrica nos municipios de São Paulo (...)" Grafia como no original. Além da Light, outra empresa de capital estrangeiro (a Cia. City de Urbanização) teve papel relevante na destinação dos bens imóveis expropriados à margem do Rio Pinheiros. Pense-se tão somente no atual bairro City Boaçava. Para uma análise das relações entre ordem jurídica e
} 
questão levada ao Supremo centrava-se na categoria dogmática da retrocessão - conforme o Código Civil de 1916 então a definia (art. 1150, CC 1916) - dos bens imóveis expropriados pelo executivo estadual e pela Companhia Light. Naquele momento, os particulares que haviam sido expropriados expressaram perante o judiciário sua contraposição a alguns aspectos relacionados à perda da propriedade em favor daquele híbrido de público e privado. Concretamente, embora se tratasse de retrocessão, isto é, o direito de ex-proprietário reaver a coisa pelo mesmo valor da desapropriação em caso de o bem não ter sido destinado à utilidade pública para a qual se desapropriou, a discussão cingia-se, ou ao menos poderia ser lida, como um debate acerca dos limites do uso público da propriedade privada. Os expropriados contestavam o papel que a Light havia desempenhado ao longo do processo de desapropriação e a legitimidade que esta teria para promovê-la.

Se o poder executivo estadual criou os critérios para a declaração de utilidade pública, foi a Companhia Light que arcou com pagamento das indenizações, foi a destinatária dos bens expropriados e, em alguns casos, os revendeu com lucro. Uma das grandes polêmicas ligadas ao caso dizia respeito aos critérios para a delimitação da área a ser expropriada, isto é, definir, afinal, a amplitude da zona $^{7}$. Isto porque a extensão da zona a ser desapropriada seria determinada pela cheia do ano de 1929 e, afirma-se ${ }^{8}$, a Companhia Light, por controlar a vazão dos reservatórios do Rio Pinheiros, seus afluente e eclusas, poderia ter causado uma cheia mais extensa do que a devida às chuvas e, desse modo, teria sido capaz de ampliar a área que obteria por força da desapropriação.

As relações então existentes entre a empresa concessionária, o Governo estadual e os particulares expropriados envolviam diversos outros aspectos, provavelmente o principal deles decorria do fato de a área desapropriada ser, no modelo adotado, a forma de remuneração para a execução de uma obra pública de saneamento, inversão de curso e retificação do Rio Pinheiros. Todos esses melhoramentos seriam executados na várzea do rio a fim de mitigar os efeitos de futuras cheias. Em outros termos, as obras no curso do rio seriam executadas pela

desenvolvimento urbano em São Paulo no início do século XX, ainda que não especificamente relacionado ao caso em apreço, cf. ROLNIK, Raquel. A Cidade e a Lei: Legislação, política urbana e territórios na cidade de São Paulo. São Paulo: Studio Nobel, 1997.

${ }^{7}$ Ainda que o instituto da desapropriação por zona só tenha sido introduzido em nosso direito com o art. $4^{\circ}$ do Decreto-Lei 3.365/1941.

${ }^{8}$ Esta é a percepção consignada em SEABRA, Odette C. L. Os Meandros dos Rios nos Meandros do Poder: Tietê e Pinheiros valorização dos rios e das várzeas na cidade de São Paulo. São Paulo: Departamento de Geografia da Faculdade de Filosofia, Letras e Ciências Humanas da Universidade de São Paulo, 1987 (Tese de Doutorado). 
empresa canadense e o pagamento seria a diferença entre: (i) o valor pago a título de indenização aos ex-proprietários e custo das obras; (ii) as receitas advindas da valorização imobiliária gerada pelas melhorias decorrentes da execução da melhoria. Com algum anacronismo, seria possível caracterizar o arranjo empreendido pelo governo paulista e a Companhia Light como uma forma de cooperação público-privada na medida em que o privado vale-se de uma prerrogativa do poder público para, com meios próprios, gerar um valor para a sociedade e, posteriormente, remunera-se com as tarifas ou pagamentos oriundos dessa atividade. Claramente, a remuneração, nesse caso, adviria das operações imobiliárias.

Aliado à revenda dos imóveis não mais sujeitos às intempéries do Rio Pinheiros, o grupo Light teria ganhos laterais como o aumento do potencial hidroelétrico de suas usinas de geração, além de garantia de abastecimento à sua rede transmissão e aos bondes que operava em São Paulo. De todo modo, o ponto central, por ora, a fixar é que se tratava de uma forma muito peculiar para financiamento de obras públicas. Nela a estrutura financeira do empreendimento não geraria a saída direta de recursos do caixa do Estado, mas sim, por via da instrumentalização quase privada de uma das prerrogativas estatais, o domínio eminente, a obra pública será feita e os benefícios oriundos dela capturados, em parte, pelo particular que pôde condenar em excesso ${ }^{9}$ os particulares a perderem a propriedade privada. Sem dúvida, é inquestionável que haveria a geração de valor com a expropriação, pois a obra pública não ocorreria sem ela, o problema voltava-se para os limites impostos ao poder expropriatório e a forma de repartição dos benefícios decorrentes dos melhoramentos.

Enfocado por um ângulo mais abstrato, estava-se diante de uma articulação muito pouco corrente, substancialmente polêmica, e por vezes confusa, entre o público e o privado. Com mais precisão, a complexidade da situação fática e o emaranhado de relações e interesses que envolviam o executivo estadual, a empresa privada e os proprietários demandava uma equação entre os domínios do público e do privado mais sofisticada que aquela normalmente apresentada para justificar outros atos do poder público. De igual forma, a hoje aceita noção de sujeição do particular frente ao poder estatal ${ }^{10}$, inclusive no que tange à perda do direito de propriedade, tornava-se menos palatável - e sujeita a contestações - num contexto em que

\footnotetext{
${ }^{9}$ Trata-se de uma adaptação frequentemente utilizada para a desapropriação por zona por influência do termo em inglês "excess condemnation". Cf. BELL, Abraham. "Private Takings" in University of Chicago Law Review, v. 76, n. 2, 2009, pp. 517-85.

${ }^{10}$ Questionando essa noção há: SARMENTO, Daniel (org.). Interesses Públicos versus Interesses Privados: Desconstruindo o Princípio de Supremacia do Interesse Público. Rio de Janeiro: Lumen Juris, 2007.
} 
havia a participação de uma empresa privada de capital canadense, com todas as implicações ideológicas que à época isso poderia gerar $^{11}$.

Essa equação incerta, ainda em inícios dos anos 2000, não se resolveu de modo definitivo. Basta pensar nas reações que se manifestam contemporaneamente frente à possibilidade de o executivo municipal de São Paulo delegar à iniciativa privada, mediante uma concessão urbanística ${ }^{12}$, a remodelação de uma parcela do solo urbano. Uma problemática ainda hoje é a de se determinar, afinal, se uma prerrogativa do Estado pode ser transferida ao particular-concessionário como instrumento de política urbana ou se esta prerrogativa só poderá ser exclusivamente exercida pelo Estado de forma indelegável.

A pergunta, como acima colocada, permanece sem uma resposta categórica, a despeito do considerável esforço dogmático feito à época dos fatos e de seu julgamento pelo Supremo. É, com efeito, sintomático que a experiência anterior pouco tenha sido rememorada, pois não foi fixada, não foi alçada a parâmetro para futuros debates. Assim, por não influir no debate contemporâneo sobre as relações público-privadas em desapropriações é, provavelmente, uma decorrência da baixa institucionalização da cultura jurídica, da fugacidade de sua memória. A nos fiarmos no que se produziu acerca da atual contenda em torno do bairro paulistano da Luz, é como se a várzea nunca houvera sido desapropriada e entregue, como remuneração, ao privado pela execução de uma obra pública. Ironicamente, o mesmo que se pretende fazer com a concessão urbanística na Luz, embora distintas as formas jurídicas, alteradas as respectivas denominações, na substância os dois momentos apresentam similaridades.

Adiantando ligeiramente o argumento, é a baixa capacidade de reflexão acerca da própria experiência pretérita, em fazê-la relevante ao futuro, que faz com que muitos debates jurídicos se articulem com baixa densidade histórico-problemática. Embora sejamos pródigos nos escorços históricos de toda sorte, ao ligarmos qualquer ramo do direito, por mais contemporâneo, como se fora consequência quase direta da experiência romana, somos, ao

\footnotetext{
11 “Após 1945, a Companhia [Light] viu-se tomada por problemas de amadurecimento, tanto seu quanto do Brasil, que assumiu variadas formas - nacionalismo, revoltas políticas, o crescimento econômico pressionado pelo 'milagre econômico' brasileiro e o movimento inexorável do Brasil na direção do controle nacional da energia gerada por suas águas.” MCDOWALL, Duncan. Light: A História da Empresa que modernizou o Brasil. São Paulo: Ediouro, 2008, p. 23. Igualmente representativo desse momento foram as intermitências que as operações da Light enfrentaram no Rio de Janeiro, especialmente frente às iniciativas da família Guinle. Cf. SAES, Alexandre Macchione. Conflitos do Capital: Light versus CBEE na formação do capitalismo brasileiro (1898-1927). Campinas: Instituto de Economia da Universidade de Campinas, 2008 (Tese de Doutorado), pp. 269-311.

${ }^{12}$ Prevista na Lei Municipal de São Paulo n. 13.430/2002, art. 239 e ss.
} 
mesmo tempo, parcos em fazer senso de nossa própria experiência jurídica. Assim é que um olhar pautado em demasia por uma certa leitura da experiência romana talvez perca o que fica historicamente no meio do caminho, isto é, a experiência jurídica que propriamente nos diz respeito, a aplicação do direito e das regras jurídicas no contexto brasileiro, a despeito dos problemas em se determinar os sentidos e as contradições em fazê-lo ${ }^{13}$.

Com efeito, um dos pontos nevrálgicos da disputa que se articulou em torno do projeto estadual de saneamento da várzea do Rio Pinheiros consistia em arbitrar limites à atuação do Estado. Ironicamente - ou, talvez, sintomaticamente - pouco disso resta refletido nos debates jurídicos que se travaram a respeito. Essa leitura se confirma pela análise dos documentos do Supremo Tribunal Federal e dos pareceres que nos chegaram a respeito do caso. Em grande medida, o debate jurídico se estruturou em torno da viabilidade técnico-jurídica do pedido de retrocessão, isto é, foram debates interessantes em torno da aplicabilidade da categoria dogmática disponível aos expropriados que pretendiam questionar o fundamento da perda da propriedade em favor do concessionário por ato do poder público.

Um jurista moderno ${ }^{14}$ formularia o problema em outras bases, possivelmente se valeria do desvio de finalidade, do excesso de poder, e de outras categorias do direito público que, à época, encontravam-se apenas em formação. O uso judicial da retrocessão, portanto, ao invés representar um desvio ou um erro de estratégia contenciosa, confirma o truísmo de que categorias jurídicas alteram-se no tempo.

Prosseguindo no argumento, constata-se que, para além da inconformidade daqueles que foram atingidos pelo projeto estadual, um passo chama a atenção, o de que se extrai desse caso uma forma peculiar de delimitação entre o público e o privado na sociedade brasileira. Decerto, quando se fala em desapropriação o óbvio é que o que está em disputa é a delimitação entre as esferas pública e a privada. Formulado de forma mais extensa, a questão é até que ponto a organização estatal pode impor ao particular o uso público do que até então constituía domínio privado e, dessa forma, constranger o particular a abster-se de exercer um direito sobre um bem e transferi-lo ao domínio público mediante compensação pecuniária.

\footnotetext{
${ }^{13}$ Guardadas as devidas distinções, veja-se o comentário de um crítico sobre o papel de Machado de Assis em tomar o real brasileiro e figurá-lo, a partir do universal fazendo, dele tema, a despeito das dissonâncias, incompletudes e do "(...) travejamento contraditório da experiência [brasileira] que seria figurada e investigada pela literatura de um grande autor [Machado]." SCHWARZ, Roberto. Um mestre na periferia do capitalismo: Machado de Assis. São Paulo: Ed. 34, 2000, p. 40.

${ }^{14}$ Analogia com o Petrônio moderno de Auerbach. Cf. capítulos II e XVIII de AUERBACH, Erich. Mimesis: A representação da realidade na literatura ocidental. São Paulo: Perspectiva, $4^{\text {a }}$ Edição, 2001.
} 
O argumento vai muito bem, porém pressupõe algo, quase que, a despeito de óbvio contemporaneamente, naquele momento era menos usual, trata-se da "prevalência do interesse público frente a interesses particulares“. Um lugar comum com uma extensa trajetória na experiência jurídica, certamente uma experiência contraditória e com diversas implicações que, de tão diversas, seria arbitrário dispor-se a expor ela toda sinteticamente. Fato é que o lugar comum hoje é prenhe de força argumentativa e se não é factível fazer-lhe a história num instante, inegável que sua origem (Ursprung ${ }^{15}$ ) não parece das mais inequívocas e bem intencionadas ${ }^{16}$. E para adicionar uma ironia que se tornou quase gasta, mas que mantém alguma vitalidade pela resiliência do ambiente intelectual e social brasileiro:

"Ao longo de sua reprodução social, incansavelmente o Brasil põe e repõe ideias europeias, sempre em sentido impróprio. “17

Em outros termos, a formação e reprodução de um lugar comum depende de uma conformação e de uma eficácia muito própria, notadamente se este lugar comum se articula com um outro de grande poderio argumentativo. No caso da desapropriação, o da intangibilidade da propriedade, o do direito de exclusão de terceiros e do Estado em se imiscuir no domínio particular. O embate e a formação deste novo ponto de apoio ao discurso jurídico possui uma estreita relação com a emergência e afirmação do próprio direito público brasileiro, especialmente o direito administrativo e suas contradições. A relação do Brasil com o direito administrativo francês ${ }^{18}$ é um exemplo a que tão bem se aplicaria o trecho Roberto Schwarz acima citado. Importações conceituais quase que descasadas ou despreocupadas com

\footnotetext{
${ }^{15}$ Cf. FOUCAULT, Michel. "La Vérité et les Formes Juridiques” in Dits et Écrits I, 1954-1975. Paris: QuartoGallimard, 2001, pp. 1412-1421

${ }^{16}$ Para um comentário instigante e interno à dogmática do direito administrativo, vide o primeiro capítulo de BINENBOJM, Gustavo. Uma Teoria do Direito Administrativo: Direitos Fundamentais, democracia e constitucionalização. Rio de Janeiro: Renovar, $2^{\mathrm{a}}$ Edição, 2008.

${ }^{17}$ SCHWARZ, Roberto. Ao vencedor as batatas. Forma literária e processo social nos inícios do romance brasileiro. São Paulo: Duas Cidades; Ed. 34, 2000, p. 29.

18 Para fazer justiça a quem se aventurou nesta relação, limitando-me ao que tive acesso, cito a Tese de Doutorado de Maria Paula Dallari Bucci (posteriormente publicado como: Direito Administrativo e Políticas Públicas. São Paulo: Saraiva, 2002) que debate as contradições do Direito Administrativo brasileiro em suas insistentes mesclas de tradições, sincretismos e novidades: a tradição francesa do Conseil d'État em um país que não adotou a dualidade de jurisdição, as agências em um federalismo ainda en quête de son identité. Em apertada síntese, quer-se com isso dizer não que temos o país errado com instituições contraditórias, mas antes que tais recepções contraditórias importam e é com elas que se deve lidar e não com a sistematização das decisões do Conselho de Estado francês. Não que tal tarefa seja desprovida de relevância teórica, contudo contradições nacionais mais prementes aguardam o seu tempo para serem enfocadas pelo olhar teórico.
} 
os problemas locais, mas não de todo irracionais, pois a incorporação da doutrina francesa atendia a anseios de distinção e do refinamento retórico ${ }^{19}$.

A desapropriação dos imóveis lindeiros ao Rio Pinheiros traz em seu bojo grande parte destes conflitos e expõe - do modo mediado próprio à elaboração jurídico-dogmática - um conflito que estava em gestação e se desenrolava na sociedade brasileira. O que interessa, porém, não é o conflito em si, decorrente que era dos fenômenos de aceleração do tempo e de coletivização da vida social tão próprios aos frementes anos $1920^{20}$, mas a sua forma de exposição jurídica, a perspectiva, por assim dizer, interna ${ }^{21}$. Ou ainda, tentar depurar, a partir dos casos, as transformações na lente que faz a mediação entre o externo para que este se torne, através da passagem, interno.

Para observar de perto essa passagem, é preciso ir aos documentos em que tal acontecimento poderá estar consignado. Um aspecto que salta aos olhos ao longo da leitura dos documentos do Supremo é o de que o direito privado gozava então de força argumentativa mais intensa que a do direito público. Ainda que o tema em análise fosse uma desapropriação, tema tão próprio à ordenação das relações entre o Estado e o privado, predominaram as menções ao direito privado, que, esquematicamente, haveria de disciplinar a relação dos particulares entre si, e, no limite, a saída da propriedade do domínio privado ${ }^{22}$. Este fato pode ter múltiplas causas, possivelmente uma delas a codificação do direito privado num corpus, ao passo que o direito público permanecia submetido a fórmulas mais contingenciais e

\footnotetext{
${ }^{19}$ Ao comentar a renitente a postura retórica dos estudos jurídicos como "elemento de continuidade cultural" em consonância com a oralidade colonial, A. Candido assim se manifesta: "É pois compreensível que se tenha propiciado a cultura jurídica (...) com toda a sua tendência para o formalismo, como orientação, através da retórica, como técnica." "Literatura e Cultura de 1900 a 1945“ in CANDIDO, Antonio. Literatura e Sociedade: Estudos de Teoria e História Literária. Rio de Janeiro: Ouro sobre Azul, 10ª Ed., 2008, p. 139.

${ }^{20}$ Sumamente interessante a este respeito é o livro do Prof. Nicolau Sevcenko acerca da poesia nos anos $1920 \mathrm{em}$ São Paulo e o modo específico como se inscrevia na poesia este processo social mais amplo. Embora este não seja em si intuito do livro, é inegável que ele perpassa a peculiar inscrição do processo social no registro escrito e que esta relação é dúplice. SEVCENKO, Nicolau. O Orfeu extático na metrópole. São Paulo, sociedade e cultura nos frementes anos 20. São Paulo: Cia. das Letras, 1992.

${ }^{21}$ A formulação de Hart certamente não converge totalmente com o que se dirá adiante, mas é sintomática que a formulação de pontos de vista interno e externo seja utilizada com mais de uma intenção explicativa. Segue o trecho da formulação de Hart: "Most of the obscurities and distortions surrounding legal and political concepts arise from the fact that these essentially involve reference to what we have called the internal point of view: the view of those who do not merely record and predict behavior conforming to rules, but use the rules as standards for the appraisal of their own and other's behavior." HART, H. L. A. The Concept of Law. Oxford: Oxford University Press, 2nd Edition, 1997, p. 98.

${ }^{22}$ É corrente o comentário de que o Código Civil de 1916 disciplinava a desapropriação não como relação de submissão Estado/cidadão, mas sim como saída do domínio privado e passagem ao âmbito dos bens públicos a serem disciplinados pelo Direito Administrativo.
} 
logicamente menos ordenadas. Nesse passo, ilustra o argumento o decreto-lei sobre desapropriações, 3.365/1941, ainda vigente, embora com sensíveis modificações.

Era, portanto, àquela altura mais simples e acessível fazer dogmática do direito privado do que lidar com as conturbadas relações do Estado brasileiro diante dos particulares para, assim fazendo, delimitar e compreender as relações entre dois polos da sujeição política. Era preciso criar um âmbito argumentativo apto a ser compartilhado e, por esse meio, tornar sustentável e efetivo o recurso a tal âmbito ${ }^{23}$. Nesse cenário apenas esboçado, é curioso que os publicistas tenham ido à França em busca de inspiração. Tal analogia custa a ser compreendida, há um sentimento de que lhe faltaria um símile adequado, um traço necessário à validade da boa analogia. Se no Brasil não havia - ao menos com as mesmas funções como na França um Conselho de Estado (embora o Império tenha mimetizado, com outras funções $^{24}$, a tradição institucional francesa), pois havíamos adotado a jurisdição una; se éramos um Estado federal e a França Estado unitário, então se torna difícil entrever o símile a subsidiar esta importação ${ }^{25}$.

Igualmente, falar de supremacia do interesse público, ou coletivo, mostrava-se uma proposição sem o mesmo apelo que se fosse pronunciada hoje. Tanto isto é verdade que ao contratarem seus pareceres para a ação no Supremo- e isso é sintomático de uma estratégia jurídica - a Light apresentou sensível predileção pelos civilistas. Ao invés de denotar uma inconsistência, essa circunstância provê algumas indicações sobre a posição e a capacidade que cada discurso possuía para influenciar a tomada de decisão jurídica. Claramente neste

\footnotetext{
${ }^{23}$ Para desde logo fazer recurso à analogia fonte desse trabalho, vale a menção à posição que Auerbach confere a Dante: "Mas, se partimos de seus predecessores, a linguagem de Dante parece um milagre quase inacreditável. (...) necessariamente se chega à convicção que este homem, através de sua linguagem, redescobriu o mundo.“ AUERBACH, Erich. Mimesis. Claro é que não se poderia requerer de um publicista esta capacidade criadora $a b$ nihilo, ainda que um diálogo mais audaz frente a seus predecessores não fosse de todo injusto requerer. Para uma observação mais consentânea, vide FOUCAULT, Michel. L’Archéologie du Savoir. Paris: Éditions Gallimard, 1969. No que tange às condições de emergência de um discurso - suas condições de possibilidade - e como elas se desenrolam menos de modo vetorial e inconteste e mais tumultuado e contraditório. Encontra-se igualmente em Foucault farto material a respeito, seja teórico na arqueologia do saber, seja aplicado em outros livros seus sobre tópicos concretos organizados a partir do projeto abstrato inscrito em seu manifesto metodológico.

${ }^{24}$ Para uma análise do órgão veja-se: "O Conselho de Estado: a cabeça do governo" in CARVALHO, José Murilo. A Construção da Ordem: A elite política imperial/Teatro das Sombras: A política imperial. Rio de Janeiro: Civilização Brasileira, 2003, pp. 355-90.

${ }^{25}$ Obviamente o compasso do argumento aqui o direciona ao absurdo. Entretanto, existiam, de fato, inúmeras motivações para que o direito administrativo tenha dirigido sua atenção para a França. Contudo, não se pode repreender aquele que verte um olhar irônico e proprositadamente descontextualiza este peculiar traço da história cultural do direito administrativo brasileiro.
} 
quesito os civilistas acabaram por sobrepujar, mesmo fora de seu campo de atuação, os publicitas de sua época.

Contudo, é preciso anotar que direito público e direito privado não são categorias tão consistentes e a-históricas de modo a servirem indiscriminadamente de focos de interpretação. No caso em análise, entretanto, salta aos olhos de um leitor contemporâneo como, de forma contra-intuitiva, categorias dogmáticas do direito privado foram manejadas à resolução de uma desapropriação. Talvez a pergunta fosse, porque não uma resolução pela mera submissão e justificação à "supremacia do interesse público"? A resposta, possivelmente, poderia vir nos seguintes termos: esse locus argumentativo ainda não tinha se constituído plenamente, estamos como que o vendo nascer, observando um conflito de emergência ainda não concluído. E disso temos evidência nos próprios autos, nos arquivos judiciários, pelo fato de haver menção aos temas de direito público por Themístocles Brandão Cavalcanti ${ }^{26}$. Ainda minoritário e sem a mesma força argumentativa que terá no decorrer do século XX, porém já presente demarcando o território que pertencerá, paulatinamente, ao direito público.

Por evidenciarem uma gênese, um movimento ainda inconcluso, analisar casos ao longo do século $\mathrm{XX}$, particularmente aqueles que contaram com grandes juristas, constitui um ponto de observação privilegiado de movimentos históricos ${ }^{27}$. A urbanização, a coletivização da vida, o papel que o Estado assumirá nesse contexto, enfim os primórdios de uma época de convivência metropolitana, ao menos em São Paulo, estão todos lá, ainda que expostos de maneira bem particular. Interessante é observar este movimento pelo ângulo interno, mediado pelo direito e sua forma de exposição, com todas as peculiaridades que essa forma de registro da realidade encerra em si. Ao apreender dogmaticamente os conflitos urbanos o jurista reduz à sua forma o movimento mais amplo da sociedade. Para além de redutor, o que é inerente a qualquer processo de mediação, essa forma de apreensão do real é criadora. De forma canhestra, pode-se afirmar isso com Antonio Candido, porquanto seriam tênues os limites entre mimesis e poiesis:

"O primeiro passo (que apesar de óbvio deve ser assinalado) é ter consciência da relação arbitrária e deformante que o trabalho artístico estabelece com a realidade, mesmo

\footnotetext{
${ }^{26}$ CAVAlCANTI, Themístocles B. "Desapropriação por Zona. Retrocessão" in Revista de Direito Público, v. 7 , 1969.

${ }^{27}$ Guardadas as devidas proporções, esse é um procedimento de que Auerbach, pretensamente, teria empregado, abrir ao acaso uma obra para mencionar um trecho, ou seja, que qualquer trecho da obra seria apto a ilustrar um ponto que faria. Cf. e.g. AUERBACH, op. cit., pp. 104 (Canção de Rolando) e 289 (Shakespeare).
} 
quando pretende observá-la e transpô-la rigorosamente, pois a mimese é sempre uma forma de poiese." 28

E se fazemos ressaltar essa característica possivelmente óbvia, é porque o jurista, muitas vezes, se vê profundamente envolvido por sua própria construção de realidade, e tal circunstancia tende a fazer com que ele se perca em sua própria perspectiva. Tal como o velho Père Goriot do romance de Balzac, que só via suas filhas pelo prisma do amor de pai, a ponto de levá-lo à perdição pela incapacidade da visada perspectiva ${ }^{29}$, também a miséria do jurista pode ser essa, a incapacidade da perspectiva e de fazer sentido da representação do outro sem recurso ao imediatamente apreensível.

Acompanhando ainda um segundo andamento do programa de Antonio Candido ${ }^{30}-\mathrm{o}$ que talvez não valha como analogia bem feita, mas certamente merece menção por ser um argumento bem construído - tem-se de reconhecer os limites da dualidade interno/externo:

"Tal método [e a menção é a Auerbach e a fusão da análise estilística com métodos histórico-sociológicos] permitirá levar o ponto de vista sintético à intimidade da interpretação, desfazendo a dicotomia tradicional entre fatores internos $e$ externos, que ainda serve atualmente [década de 1960] para suprir a carência de critérios adequados. “31

Como foi feito menção, também a teoria jurídica possui a sua versão da citada dicotomia, o que tornaria a analogia a princípio válida. Restaria, no entanto, saber até que ponto uma crítica integradora ${ }^{32}$ ou um ponto de vista sintético seria viável. Para além disso, a passagem acima não abole por inteiro a validade de perspectivas interna e externa, mas sim busca um entendimento de que fatores, externos e internos, não haveriam de ser encarados de

\footnotetext{
${ }^{28}$ CANDIDO, Antonio. Literatura e Sociedade: Estudos de Teoria e História Literária. Rio de Janeiro: Ouro sobre Azul, 10ªd., 2008, p. 22.

${ }_{29}$ Auerbach ilustra, por exemplo, a falta de perspectiva histórica da Idade Média referindo-se à forma de representação de outras épocas e culturas por meio dos tipos imediatamente sensíveis do cotidiano: "(...) a consciência perspectivo-histórica faltava, na medida em que os acontecimentos e os seres humanos daquelas longínquas épocas eram transferidos para as contemporâneas formas e condições de vida: César, Enéias, Pilatos tornaram-se cortesãos; José de Arimatéia, burguês, e Adão um camponês do século XII ou XIII, do tipo que podia ser encontrado na França, na Inglaterra ou na Alemanha.” AUERBACH, op. cit., p. 285.

${ }^{30}$ Acompanho o argumento de WAIZBORT, Leopoldo. A Passagem do três ao um: crítica literária, sociologia, filologia. São Paulo: Cosac \& Naify, 2007, p. 91.

${ }^{31}$ CANDIDO, Antonio. Literatura e Sociedade: Estudos de Teoria e História Literária. Rio de Janeiro: Ouro sobre Azul, 10ªd., 2008, p. 24.

32 "O meu propósito é fazer uma crítica integradora, capaz de mostrar (não apenas enunciar teoricamente, como é hábito) de que maneira a narrativa se constitui a partir de materiais não literários, manipulados a fim de se tornarem aspectos de uma organização estética regida pelas suas próprias leis, não as da natureza, da sociedade ou do ser." CANDIDO, Antonio. O discurso e a Cidade. Rio de Janeiro: Ouro sobre Azul, 4 a Ed., 2010.
} 
forma unilateral e independente. Trazendo para o nosso concreto, dogmática jurídica e sociologia do direito, por exemplo, permaneceriam perspectivas, interna e externa, respectivamente. Entretanto, fatores dogmáticos internos e sociológicos externos não constituiriam chaves únicas de compreensão do fenômeno, pois que, como elementos causais e explicativos, operariam de modo bem mais complexo e escorreito do que uma simples determinação direta.

Com o objetivo de agregar pontos de observação entre as perspectivas internas e externas, será preciso pinçar outro momento em que fatores explicativos internos e externos parecem divergir. Essa é, igualmente, uma maneira de se lançar as bases para um contraste, passa-se, então, à exposição sumária do outro caso a permear este trabalho. Temos mais uma vez o instituído da desapropriação por zona, feita pela Prefeitura do Município de São Paulo para a construção da estação do metro de Santana, na Zona Norte da capital paulista. Nessa oportunidade, porém, posterior, o ato expropriatório remonta à década de 1970. Novamente, temos o Supremo Tribunal Federal como cenário de um conflito urbano judicializado. Mas qual não é a diferença nos registros escritos. Os documentos judiciais, principalmente os votos dos Ministros, falam em mandado de segurança, supremacia do interesse público, poder expropriante, garantias do particular. Os termos ganham uma densidade inexistente nos relatos mais interessantes feitos do caso anterior e, mais central, o direito privado deixa de ser mencionado como fonte de categorias dogmáticas para sua resolução, mas torna-se um misto de repositório das garantias do privado frente ao poder exercido pelo Estado e um limite a esse. Bem distinta, portanto, a função em comparação ao que se observa no caso da Várzea do Rio Pinheiros.

Há a sensação de que o conflito se coloca de modo mais claro e nítido, exposto de maneira mais clara, existe inegavelmente uma forte contraposição entre a propriedade privada - o âmbito de liberdade do particular - e o poder-dever do Estado em adotar medidas aptas à consecução do bem comum. Ou seja, opõe-se dois princípios estruturantes da própria relação política do cidadão no Estado, sendo que as garantias do cidadão assumem a forma de garantias e de limites negativos à ação do Estado $^{33}$. A mudança parece sutil, mas traz em seu

\footnotetext{
${ }^{33}$ Uma definição curta dessa ideia é dada por Dworkin: "The Constitution, and particularly the Bill of Rights, is designed to protect individual citizens and groups against certain decisions that a majority of citizens might want to make, even when that majority acts in what it takes to be the general or commom interest." DWORKIN, Ronald. Taking Rights Seriously. Cambridge, Mass.: Harvard University Press, 1978, p. 133.
} 
bojo desdobramentos relevantes, dos quais se extrai, numa analogia sui generis $^{34}$, que o segundo caso promove uma figuração mais séria e problemática da relação entre o público e privado e, por tal motivo, é capaz de transmitir de modo mais intenso a particular compreensão da dualidade naquele momento. Posto de outro modo, ao esmiuçar e fundamentar com mais presteza os pontos de argumentação, os votos dos ministros do Supremo aclaram posições ideológicas mais marcadas. Permitem, assim, que se acesse um material mais rico em que argumentos e oposições transmitem um senso mais denso da realidade ${ }^{35}$ na qual o conflito se coloca.

Insistindo em analogias talvez imperfeitas, tem-se outro excerto de Roberto Schwarz que, ao comparar o romance de José de Alencar ao de Machado de Assis, provê uma chave de leitura mais ampla do que a da teoria literária:

"Não sendo metáforas da totalidade social [aquilo figurado por Alencar], perversão, vida mundana, tédio, alfaiates e sapateiros da moda reduzem-se a chamariz, superpostos sem muito disfarce à falta de prestígio de nossa rotina brasileira. Não que esta fosse desprovida de profundidade - como adiante se verá com Machado de Assis. Mas seria preciso construíla." 36

Ou seja, também o direito público terá que construir o seu modo de representação problemático, ele não estava dado de antemão, não estava pronto e acabado. E se pegamos dois pontos e os colocamos lado a lado aclara-se esta profundidade dessa rotina brasileira que é, paulatinamente, figurada com mais presteza e aptidão. Visto de outro modo, ainda que não transparecesse em um primeiro momento, seja no romance de José de Alencar, seja na decisão da Várzea do Rio Pinheiros, houve alterações profundas na forma de representação em desdobramentos posteriores. Ao olhar apenas para José de Alencar ou para a desapropriação do Rio Pinheiros aquelas realidades se apresentam como totalidade, mas será apenas na comparação que suas estruturas profundas transparecerão. A matéria, se não é constante, pouco se alterou, no entanto a forma da exposição sofreu mudanças significativas.

\footnotetext{
${ }^{34}$ Em virtude de ter por base o filólogo alemão Erich Auerbach e seu texto de síntese, Mimesis.

${ }^{35}$ Uma primeira caracterização deste tema pode ser encontrado em CANDIDO, Antonio. "A Personagem do Romance” in ROSENFELD, Anatol et al. A personagem de ficção. São Paulo: Perspectiva, 1961, pp. 51-80.

${ }^{36}$ SCHWARZ, Roberto. Ao vencedor as batatas. Forma literária e processo social nos inícios do romance brasileiro. São Paulo: Duas Cidades; Ed. 34, 2000, p. 66.
} 
Do mesmo modo que Machado de Assis é o ponto de fuga n'A Formação da Literatura Brasileira $^{37}$, pois nele a forma romance que figura o processo social local se resolve com particular lucidez, também se houvesse uma formação do Direito público brasileiro, haveria um ponto de fuga em que as tensões e conflitos entre público e privado se resolveriam de modo mais lúcido e consciente de si. Certamente, nesta formação o caso do Rio Pinheiros seria um passo e não o ponto de fuga. Isso porque seria desigual comparar a fina apreensão e exposição dos conflitos sociais por Machado de Assis às formas jurídicas de narrativa do real feitos até mesmo pelos mais atentos Ministros do Supremo Tribunal Federal.

Isso porque a forma jurídica e o processo social no caso do Rio Pinheiros parecem ainda em estranhamento profundo, quase não se tocam e em quase nada convergem os relatos, ainda que os fatos sejam os mesmos. Isso se evidencia, por exemplo, por trechos jornalísticos sobre a enchente de 1929, um dos contextos fáticos centrais do caso levado ao Supremo Tribunal Federal. Seja na Folha da Manhã, contemporânea aos fatos, seja em relatos acadêmicos mais próximos a nós ${ }^{38}$, reputa-se a enchente como uma grande tragédia que se abateu sobre moradores das várzeas do Rio Pinheiros.

Se, no entanto, nos fiássemos unicamente nos relatos jurídicos, tratar-se-ia de mera forma de delimitação de uma zona de desapropriação. Certamente que o mecanismo de abstração operacionalizado pela dogmática estabiliza o conflito e o categoriza para preparar a decisão. Todavia, sob pena de se tornar completamente inócuo, este proceder haveria de ser, de algum modo, permeável ao processo social. Não que a dogmática se reduza ao próprio processo social e deva perder, por consequência, o seu domínio próprio, mas o referido processo possui a sua relevância na economia da tomada de decisão.

A que devemos essa figuração tão díspar dos eventos em torno da desapropriação, entre tragédia e mero procedimento técnico de subsunção? Como seria possível preparar a síntese entre, de um lado, a enchente como pungente tragédia humana e, de outro, mero mecanismo de delimitação do perímetro da área expropriada?

Muitas das decisões jurídicas anteriores sobre desapropriações, particularmente aquelas em que a exposição é feita de modo menos problemático, transparecem ser alheias aos

\footnotetext{
${ }^{37}$ SCHWARZ, op. cit. p. 40.

${ }^{38}$ A menção é a SEVCENKO, Nicolau. Orfeu Extático na Metrópole. op. cit., p. 133 e SEABRA, Odette C. de Lima. Os Meandros dos Rios nos Meandros do Poder: Tietê e Pinheiros valorização dos rios e das várzeas na cidade de São Paulo. São Paulo: Departamento de Geografia da Faculdade de Filosofia, Letras e Ciências Humanas da Universidade de São Paulo, 1987 (Tese de Doutorado).
} 
desafios de seu tempo. Não há, por exemplo, sequer uma palavra sobre o crescimento demográfico e seus conflitos na decisão da várzea do Rio Pinheiros. Poder-se-ia dizer que se tratava de elemento extra-jurídico, que não interessava à tomada de decisão e, portanto, não teria de, necessariamente, ser tomado em consideração pela decisão jurídica.

Certamente, poderia ser plausível o argumento, porém ao colocarmos frente a frente dois momentos, criam-se os contrapontos a estes mesmos argumentos. Em concreto, quando o conflito da construção de um meio de transporte público numa grande metrópole foi alçado ao Tribunal, então considerações acerca da premência da obra, de seu caráter prioritário e sua essencial importância, todas elas questões eminentemente de fato, foram apresentadas sem que isso constituísse uma quebra do protocolo jurídico.

Percebe-se da leitura seguida dos dois casos que uma grande distância, não apenas temporal, os separam. Uma grande mudança se operou entre o Rio Pinheiros e o Largo de Santana. Ainda que enumerar todas elas seja complexo, o contraste evidencia aquilo que uma enumeração pormenorizada não captaria.

Neste passo encontramos, pelo método, novamente Auerbach. O último capítulo de Mimesis deixa escapar não apenas a apreciação crítica de Virginia Woolf e Proust, mas também a concepção do filólogo sobre o seu próprio trabalho:

"Confia-se mais nas sínteses, que são obtidas mediante o exaurimento de um acontecimento quotidiano, do que num tratamento global e cronologicamente ordenado, que persegue o tema do princípio ao fim, empenhado em não deixar de fora nada exteriormente essencial e que salienta energicamente as grandes mudanças do destino como se fossem articulações do acontecer."

E segue fazendo convergir o procedimento da estruturação do romance a um modo de fazer filologia:

"Pode-se comparar este procedimento dos escritores modernos com o de alguns filólogos modernos que acham que da interpretação de poucas passagens de Hamlet, Fedra ou Fausto podem-se obter informações mais importantes e decisivas sobre Shakespeare, Racine e Goethe e sobre suas épocas, do que a partir de conferências que tratam sistemática e 
cronologicamente das suas vidas e das suas obras; o presente trabalho pode ser tomado como exemplo disso. “39

Numa paráfrase de Auerbach, dificilmente seria factível escrever uma história das relações entre o público e o privado na jurisprudência brasileira, perder-nos-íamos em épocas, autores e dificilmente se chegaríamos a algum resultado palatável ou que fosse de interesse ${ }^{40}$. Ao revés, ao pinçar dois casos em que parece ter havido uma particular forma de relação entre o público e o privado, daí acreditamos ser viável extrair uma perspectiva de interesse, não totalizante e tampouco de uma amostragem numericamente representativa, são tão somente dois casos. Nada obstante, são dois casos de grande peso para o qual juristas significativos verteram seus olhares apreensores da realidade e é pela análise desse olhar que se visa obter as informações num movimento análogo ao da obtenção de dados acerca de Shakespeare, Racine e Goethe, e sua respectivas épocas, ao se olhar para Hamlet, Fedra ou Fausto. Isso porque a obra do jurista são seus pareceres, decisões, peças judiciais, e esses documentos constituem o objeto por excelência do presente trabalho na medida em que são instrumentos para se acessar uma particular ordenação do real como jurídico. Em síntese, o modo de exposição, a forma de organização do assunto, muito diz sobre aquele que expõe e sua época ${ }^{41}$; e em que medida este é capaz de filtrar, ser um ponto focal, do momento. Falando com Auerbach captar o movimento das forças históricas.

Em certo sentido, também o historiador Carlo Ginzburg ${ }^{42}$ se viu às voltas com uma questão que se nos coloca. Afinal, quão representativo é um caso? Em seu $O$ Queijo e os Vermes esta problemática se colocava do seguinte modo: são válidas as ilações sobre a cultura popular na Idade Média a partir de um caso mediado pelo registro escrito? Num tempo de debates em torno de uma estatística histórica, o que diria o caso de Mennochio sobre a cultura

\footnotetext{
39 AUERBACH, Erich. Mimesis: A representação da realidade na literatura ocidental. São Paulo: Ed. Perspectiva, $4^{\text {a }}$ Ed., 2001, p. 493.

${ }^{40}$ Eis a fonte: "Nunca poderia ter escrito algo como a história do realismo europeu; ter-me-ia afogado na matéria, deveria ter entrado em desesperadas discussões acerca da delimitação das diferentes épocas, da classificação dos escritores nas mesmas e, sobretudo, acerca da definição do conceito de Realismo.“ AUERBACH, op. cit., p. 493.

${ }^{41}$ Auerbach em menção à "limitação da consciência histórica" de Petrônio para figurar de maneira séria e histórico problemática o cotidiano afirma que, se o fizesse, “(...) isto teria explodido o estilo dentro do qual Petrônio pretendia se manter, o que não teria sido possível sem uma ideia, que lhe era inacessível: a ideia de 'forças' históricas." AUERBACH, op. cit., p. 28.

${ }^{42}$ Cf. Introdução em GINZBURG, Carlo. O queijo $e$ os vermes: $O$ cotidiano $e$ as ideias de um moleiro perseguido pela Inquisição. São Paulo: Cia. das Letras, 2006.
} 
popular na Idade Média? Por qual razão ele seria representativo se, com mais propriedade científica, o eram as largas amostragens estatísticas?

Essa questão também nos poderia ser dirigida, por qual razão não se fez um levantamento estatístico das desapropriações no século XX? Por um motivo sutilmente simples, porque este dado nada diria à pergunta do modo como ela foi aqui formulada. Isto é, a representação problemática do cotidiano na jurisprudência e no pensamento jurídico. Para este intuito, um caso bem documentado possui maior significância (para nos mantermos na metáfora estatística) do que toda uma extensa série temporal. Não que não seja válida a pesquisa com grandes amostragens, apenas ela não é aqui o objeto.

Do dito transparece, portanto, a posição central que o caso ocupa na estrutura do argumento ora desenvolvido. A forma específica como a dogmática jurídica lidou com as circunstâncias do caso, o modo como os juristas o conceberam nos limites da dogmática jurídica de seu tempo. São estes os pontos que se quer fazer, afinal como a dogmática se altera no tempo e como tal alteração se liga a uma forma interna de organização dos estímulos externos $^{43}$.

Por esse fundamento, o caso e as circunstâncias fáticas desempenham um papel relevante na investigação. Por isso, fixar, ainda que em linhas gerais, os pontos de partida constituirá parte substancial da empreitada.

Assim, tem-se que os proprietários de bens imóveis próximos ao que hoje é a estação do metrô de Santana, zona norte da capital paulista, contrapuseram-se à ação da prefeitura municipal e de um órgão de sua administração indireta, a EMURB (Empresa Municipal de Urbanização). O intento do executivo municipal era desapropriar área superior à necessária para as obras civis do Metropolitano com a finalidade de, ao apropriar-se de parte da valorização imobiliária decorrente, financiar o investimento público em infra-estrutura urbana. O instrumento manejado foi, também aqui, a desapropriação por zona. Os particulares novamente se contrapuseram, porquanto perderiam em um primeiro momento suas casas, imóveis comerciais, etc. $\mathrm{O}$ instrumento que usaram os moradores nesta ocasião foi um mandado de segurança preventivo diante da iminência da expedição do decreto de utilidade pública da área, fundado em legislação vigente.

\footnotetext{
${ }^{43}$ A menção, indireta, aqui é a CANDIDO, Antonio. "Estímulos da criação literária“ in Literatura e Sociedade, op. cit., pp. 51-80.
} 
A controvérsia jurídica foi tão profunda que a decisão no STF permaneceu pendente por um largo período e se resolveu pela entrada de um novo ministro que votou, acompanhando outros, pelo não conhecimento da ação. Juristas de análise acurada apresentaram posicionamento diverso do adotado, por maioria, pelo Supremo. Dentre eles, pode-se contar, por exemplo, Miguel Seabra Fagundes que, embora não atuando no caso, posicionou-se, do ponto de vista teórico, contra a desapropriação por zona da forma como ela fora utilizada pelo município de São Paulo. Sua posição era contrária à desapropriação por zona ao divergir da possibilidade de sua aplicação após o advento do mecanismo tributário de captura da valorização imobiliária, a contribuição de melhoria ${ }^{44}$.

Por ora, isto é o que basta dizer sobre os casos. Duas desapropriações por zona, dois conflitos entre o Estado e particulares, ambos levados ao Supremo Tribunal Federal. Cabe, então, expor o intuito de aproximar estes dois momentos da jurisprudência da Corte brasileira.

Basicamente, a ideia é aproximar dois casos para deles extrair um contraste, perceberlhes a diferença ao compará-los. Para além de servirem ao contraste, os dois casos também configuram pontos de partida, Ansatzpünkte, para a análise que aqui se tenta. Uma distinção que de logo se desponta entre eles é o fato de o aprimoramento do debate em torno do caso ser mais forte no caso do metrô de Santana. Isso porque, embora o caso da Várzea do Rio Pinheiros tenha sido publicado na Revista de Direito Público ${ }^{45}$, foi o caso da década de 1970 que, por si, foi objeto de uma tese de doutorado de um administrativista de relevo ${ }^{46}$. Ao que tudo indica, o momento do metrô de Santana encontrou um cenário acadêmico mais propício a comentar decisões do Supremo Tribunal Federal. Isso pode, a um olhar apressado, parecer trivial, mas expõe uma sensível alteração nos ânimos acadêmicos entre os dois momentos. Se denominar o acórdão do Supremo de obra não for forçar o argumento - e aqui se faz uma nova aproximação com o fundamento teórico do trabalho - então dizer que o público do Supremo encontrava-se com outra disposição não seria de todo arbitrário.

Chega-se, dessa maneira, a dois pontos de importância para o argumento. Em primeiro lugar, o de que houve mudança entre as duas desapropriações postas lado a lado e que esta mudança implicou uma alteração na forma como o sistema de autor (obra), público e tradição

\footnotetext{
44 SEABRA FAGUNDES, Miguel. "Urbanização - Renovação - Desapropriação - Retrocessão”. Parecer. Revista de Direito Administrativo, v. 132, 1978, pp. 236-241.

${ }^{45}$ Revista de Direito Público - RDP. São Paulo: Revista dos Tribunais, n. 7, 1969.

${ }^{46}$ A referência aqui é a Tese de Doutorado do Professor Adilson Dallari Desapropriação para Fins Urbanísticos. O trabalho acadêmico foi posteriormente publicado pela Editora Forense em 1981.
} 
se constituía e como as relações se formaram entre esses pontos da triangulação ${ }^{47}$. Adilson Dallari era um público, qualificado, daquela decisão do tribunal e o fato de a ter filtrado, debatido e publicado nos moldes de uma Tese de Doutoramento muito diz sobre o que separa a década de 1970 dos idos da década de 1920. Teria havido algo como um amadurecimento dos grupamentos acadêmicos sobre os quais as decisões judiciais repercutem.

Embora isso possa constituir uma antecipação do argumento, fato é que os juristas não se debruçaram, mesmo muito depois, sobre o momento da primeira desapropriação como fizeram historiadores e geógrafos ${ }^{48}$. A lógica de inclusão/exclusão de um assunto em um grupo organizado de pessoas - no caso, tem-se em mente os juristas - possui caráter sintomático. Decerto, a institucionalização e perenização por meio de uma Tese de Doutorado poderia ser estranha naquele primeiro instante do século $\mathrm{XX}$. O fato de não o ser mais na década de 1980 provê indícios de transformação e, concomitantemente, alguns fios para a interpretação de tais alterações.

Os juristas no século XX, seus debates e formas institucionais não configuram, contudo, o ponto central desse trabalho, ainda que, como obra de juristas e suas instituições, enfocar a decisão passará, de algum modo, por considerações sobre os juristas como grupo. $\mathrm{O}$ objeto, como já se mencionou, é análise de dois casos em que foi necessária delimitação entre público e privado em decisões jurídicas. Dois momentos postos em contraste, pois não se intenta retomar toda a história dessa delimitação, mas sim a partir de dois pontos de particular concentração de esforços dogmáticos - de apreensão jurídica do real - observar como os juristas produziram obras representativas de uma forma de apreensão, que, então, lhes era própria. Mediatamente, assim fazendo, os juristas legaram uma específica e historicamente delimitada concepção de sua sociedade sobre esta delimitação na dualidade o público e o privado, e seus limites por vezes pouco definidos. Ou, pensado a partir da literatura por Antonio Candido:

"Na verdade, o que interessa à análise literária é saber, neste caso, qual a função exercida pela realidade social historicamente localizada para constituir a estrutura da obra,

\footnotetext{
47 "Não obstante - ainda mais quando não pretendo discutir a ideia de 'sistema' - é o caso de deixar claro que, rigorosamente falando, o sistema triangula produtores (autores), receptores (público) e um sistema de transmissão (tradição) conforme se vê em Antonio Candido (...)“ WAIZBORT, Leopoldo. A Passagem do três ao um: crítica literária, sociologia, filologia. São Paulo: Cosac Naify, 2007, p. 143, n. 152.

${ }^{48}$ Neste passo a referência volta, de forma parcial a SEVCENKO. op. cit. e de forma central a SEABRA, Odette, op. cit.
} 
isto é, um fenômeno que se poderia chamar de formalização ou redução estrutural dos dados externos." 49

O argumento que se fará aqui, portanto, é o de que haveria uma linha de continuidade entre obra jurídica, entre a dogmática, e o processo social que lhe subjaz. Inegavelmente, não se trata de uma linha de continuidade/determinação, mas uma linha de continuidade/mediação de um matiz muito específico. A formação social da dogmática jurídica - se é adequado falar com palavras eloquentes - transitou ao longo de inúmeros momentos e por caminhos sensivelmente tortuosos. Vindas e idas que dificilmente poderiam ser recapituladas com intenção de completude. Por este fundamento, aqui tomamos somente dois destes infinitos momentos, sendo que sua temática foi restringida com fins a propiciar um contraste mais marcado e, de certo modo, independente da variação temática mais marcada entre os casos. São enfocados dois casos do Supremo Tribunal Federal em desapropriações por zona. Não obstante a pequena amostragem, entreviu-se nesses dois instantes, pinçados à infinidade de casos daquela corte, em primeiro lugar, uma relação entre eles e, em segundo, o que eles revelam sobre certas mudanças operadas nos anos que os separam.

Quando se fala em mudanças, contudo, a referência não se dirige a mudanças de toda sorte, mudanças na consciência, na estrutura econômica e social, etc. Antes são mudanças na forma como se estrutura a passagem do processo social ao registro propriamente jurídico, isto é, à decisão judicial e ao parecer jurídico. Tais formas de passagem parecem ao observador que lhe é contemporâneo como sumamente naturais, simples desdobramentos da realidade contemporânea em que ele se encontra imerso. Qual não é, porém, o espanto que causa quando, distantes temporalmente, esses mesmos documentos postos em perspectiva, por meio da comparação entre duas ocasiões, deixam transparecer, então, parte daquilo que os diferencia: seus fundamentos, seus pontos de vista, as escolhas internas de ordenação de seu conteúdo.

No que está em análise, salta aos olhos o fato de a proeminência argumentativa transitar do parecer ao acórdão. Se no caso da desapropriação da várzea do Rio Pinheiros quem com mais relevância se posiciona são os jurisconsultos, porquanto Vicente Ráo, Castro Nunes e Themístocles Brandão Cavalcanti é que estão em primeiro plano. A decisão do

\footnotetext{
${ }^{49}$ CANDIDO, Antonio. O discurso e a cidade. Rio de Janeiro: Ouro sobre Azul, $3^{\mathrm{a}}$ Edição, 2004, p. 28.
} 
Supremo Tribunal Federal no Recurso Extraordinário, por seu turno, restringe-se a breves páginas e palavras, pois parte substancial das apreciações jurídicas estão nos pareceres.

Distintamente ocorreu no caso do metrô de Santana, são agora os Ministros do Supremo Tribunal Federal alçados a arautos dos problemas jurídico-dogmáticos do caso. Discute-se longamente os fundamentos da desapropriação, sua plausibilidade jurídica, até mesmo Le Corbusier ${ }^{50}$ é convocado, por meio de uma citação, a explicar os contornos e problemas do fenômeno urbano moderno. Se os jurisconsultos externos ao Tribunal tiveram influência na tomada de decisão e em seu processo decisório é difícil hoje precisar ${ }^{51}$. Certo é que não ficaram inscritos com tanta veemência como no caso do Rio Pinheiros e as referências a eles são laterais no corpo do mais acurado trabalho a respeito, a tese de doutorado do Professor Adilson Dallari. Por outro lado, notam-se claras referências ao relator do caso no Tribunal de Justiça de São Paulo, o então desembargador Kazuo Watanabe ${ }^{52}$.

Em outros termos, para além de minúcias históricas, esses detalhes constituem sinais de uma mudança operada pelo tempo que separa os dois acórdãos, algo como um deslocamento - e isso não passa de uma hipótese que necessitaria de mais dados empíricos para confirmar uma afirmação desta amplitude - do discurso teórico consistente de pareces às decisões e acórdãos propriamente como centros da argumentação. Claro que o microcosmo de análise seria capaz de distorcer essas conclusões, afinal são dois casos somente. Entretanto, como foi afirmado, eles são representativos, ainda que não quantitativamente representativos, principalmente porque foram vetores a congregar relevantes juristas contemporâneos em sua apreciação, levaram pessoas a se debruçar sobre a sua problemática. Por essa razão, chegaram a nós relatos interessantes sobre as controvérsias jurídicas que os casos envolviam, seja na forma de pareceres ou votos de ministros. Ambos à sua maneira possuem a relevância de promoverem um relato histórico-factual mesclado à caracterização jurídica desses fatos. Posto de outro modo, esses relatos são exemplos bem acabados do proceder propriamente jurídico, da redução dos fenômenos às categorias jurídicas.

\footnotetext{
${ }^{50}$ Voto do Ministro Leitão de Abreu no RE 82.300. Citado em DALLARI, Adilson de Abreu. Desapropriação para fins urbanísticos. Rio de Janeiro: Editora Forense, 1981, pp. 162-3.

${ }_{51}$ Os registros mostram que Hely Lopes Meirelles ofereceu um parecer em favor da posição da Prefeitura de São Paulo. Cf. EMURB. A Reurbanização de Santana e Jabaquara: Memorial para o julgamento de Mandados de Segurança. São Paulo, 1973, pp. 27-49.

52 Cf. Mandado de Segurança 220.706 do Tribunal de Justiça de São Paulo. Publicado em Revista de Jurisprudência do Tribunal de Justiça do Estado de São Paulo, v. 26, $3^{\circ}$ Trimestre, 1973.
} 
O interesse em contrapor os dois exemplos dessa redução, ou abstração do fenômeno ao jurídico, é compreender, no microcosmo, alguns dos mecanismos dessa abstração, isto é, como ela ocorre e como, entre si, elas distinguir-se-iam historicamente. Com efeito, há dupla acepção nesse contraste. Por um lado, as decisões são, a seu modo, exemplares da forma de proceder jurídica, porém o relevante para o argumento é o fato de este proceder jurídico não ser estático historicamente. Tal mecanismo altera-se no transcorrer do tempo. Assim é que, ao serem contrastados, torna-se possível dar relevo a modos específicos da forma de abstrair do real ao jurídico, ou melhor de uma pretensa criação de realidade intra-jurídica.

Além disso, a tomada de decisão acerca da desapropriação, os argumentos e a ordenação dos elementos fáticos a justificar a medida, informam muito sobre o modo como uma decisão jurídica passa a arbitrar entre o público e o privado. Até mesmo a ausência de um posicionamento mais definido a respeito torna-se representativo do estado em que se encontrava esta questão entre os juristas brasileiros. Esta "desarmonia" entre o que encontramos nos textos jurídicos da época e aquilo que um leitor contemporâneo esperava encontrar constitui um objeto de análise por si, pois evidencia a mudança de mentalidade esse estranhamento.

Se a desapropriação pressuporia, necessariamente, um arbitramento em termos de direito público entre particular e Estado e se não encontramos tal arbitramento nas decisões, então temos que este descompasso decorre da falta de um léxico de transposição, no caso do Rio Pinheiros - o direito público - mas que se encontra mais bem formado, ainda que com todas as suas contradições, quando nos deparamos com a desapropriação do metrô de Santana.

Descompasso, desarmonia e ausência são todos termos tomados de empréstimo à análise que Roberto Schwarz faz da primeira fase de Machado de Assis e, preliminarmente, de José de Alencar. No entanto, ao invés de constituir uma falha, uma desvantagem, uma má figuração, tem-se, tanto no romance que figura de modo incompleto o processo social como na decisão que arbitra de modo canhestro, um retrato bem próprio do andamento da cultura nacional. Nosso problema é, em certo sentido, comparável à posição de José de Alencar ao se referir ao "tamanho fluminense", 53 , tamanho de acordo com o qual "talha os seus personagens". Aos que o reprovavam por uma figuração pouco ampla, José de Alencar como que respondia fazer o possível com aquilo que tinha sob os olhos. Consciente ou não, ele

\footnotetext{
${ }^{53}$ SCHWARZ, op. cit. p. 68.
} 
respondia a seus críticos com uma formulação da contradição entre a forma romance e o cotidiano esvaziado brasileiro ${ }^{54}$.

Nesta mesma toada, seria por demais óbvio simplesmente repreender às decisões jurídicas brasileiras a ausência do aspecto que estamos a chamar de arbitramento entre o público e o privado. Mais acurado será ver nas ausências traços sintomáticos do modo de articulação do jurídico frente ao processo social.

Também é possível inscrever esta ausência num âmbito mais amplo, tal como Schwarz faz em relação à ausência do romance como história, à la Balzac ${ }^{55}$, no Brasil:

“(...) os nossos romancistas ficavam sem apoio, eram obrigados a fazer ideologia, historiografia e ficção ao mesmo tempo, e de um jeito ou de outro pagavam a sua multa à cultura nacional pouco encorpada." ${ }^{, 56}$

De certa maneira, também os juristas brasileiros pagaram sua multa, ainda que sem o perceber, à ausência de uma tradição jurídica consistente e, talvez, continuem a pagar. De todo modo, a questão que se coloca é simplesmente não de uma pretensa cultura nacional, mas como os juristas ordenaram seu problema frente às mencionadas ausências.

Valer-se da desapropriação para ordenação da sociedade e dos problemas inerentes à coletivização/expansão urbana pressupõe a delimitação que mencionamos. Sem dúvida, tal arbitramento é bem pouco estático, porquanto por vezes os limites do público se expandem e retraem ao sabor das justificações que encontram. Ao que tudo indica, a forma desapropriação foi preenchida de modo desarmônico pela coloração local, e é isso que caberá observarmos mais de perto.

E tendo-se em mente que é de Auerbach e do direito que se fala, caberá, antes de se passar às desapropriações propriamente ditas, um breve excurso sobre um dos pontos mais significativos do direito na obra mestra de Auerbach.

\footnotetext{
54 "Eis o nosso problema que torna: importávamos um molde, cujo efeito involuntário é dar às idéias estatuto e horizonte - timbre, energia, crise - em desacordo com o que a vida brasileira lhes conferia." SCHWARZ, op. cit. p. 53.

${ }^{55}$ Esta caracterização de Balzac encontra-se, dentre outros, no capítulo 18 (Na Mansão de la Mole) de Mimesis, particularmente na p. 430 da edição brasileira.

${ }^{56}$ SCHWARZ, op. cit. p. 157.
} 


\section{Excurso: Uma Breve Passagem sobre o Direito em Mimesis}

Entre le boudoir bleu de madame de Restaud et le salon rose de madame de Beauséant, il avait fait trois années de ce Droit parisien dont on ne parle pas, quoiqu'il constitue une haute jurisprudence sociale qui, bien apprise et bien pratiquée, mène à tout.

Honoré de Balzac ${ }^{57}$

No capítulo em que são analisados dois trechos da História dos Francos de Gregório de Tours, E. Auerbach faz uma rápida menção a um debate ocorrido entre Gabriel Monod e Fustel de Coulanges entre os anos de 1886 e 1887. Esta curta passagem é, no texto, uma abertura para acessarmos um debate ao qual Auerbach não deveria ser alheio, e que, contudo, não se propôs a enfrentar naquele momento por não se tratar de algo essencial à condução de seu argumento. Por tal motivo, insere a referência em seu texto, para remeter o leitor interessado à fonte da controvérsia sobre a exposição do direito em um texto histórico, ou, a nos fiarmos na forma como Fustel de Coulanges caracteriza a controvérsia, remeter o leitor à fonte de uma disputa entre analyse historique (apresentada e defendida por Coulanges) e o rapprochement ou comparaison (sendo que esta estratégia metodológica é criticada por Fustel de Coulanges a partir do exemplo, ironicamente chamado de brilhante ${ }^{58}$, que é o texto de Monod). Embora Coulanges reforce o matiz de seu texto no sentido de conferir-lhe preponderantemente o sentido de uma disputa teórica em torno da maneira adequada de se escrever história, há igualmente outra chave de leitura, que será aqui privilegiada. O debate entre os historiadores franceses pode ser analisado como uma disputa em torno das possibilidades de o historiador se valer de uma legislação, hipoteticamente vigente à época, para a explicação dos fatos históricos imperfeitamente narrados por Gregório de Tours. A questão seria, pois, se, diante de uma narrativa pouco precisa e permeada de lacunas, seria

\footnotetext{
${ }^{57}$ BALZAC, Honoré de. Le Père Goriot. Paris: Pocket, 2001, p. 91.

58 "Je choisis le spécimen le plus brillant et le plus séduisant qui en ait paru depuis plusieurs années, je prends le commentaire que M. Monod vient de publier dans la Revue Historique d'um récit de Gregoire de Tours sur les aventures de Sichaire." FUSTEL DE COULANGES, Numa Denis. "L'Analyse des Textes Historiques" in Revue des Questions Historiques, 21ere Année, Tome 41 ${ }^{\mathrm{e}}$, 1887, p. 6. Se este comentário de Coulanges pode ou não ser visto como "o humor um tanto matreiro tão característico dos franceses", que Auerbach identifica em Rabelais, é uma questão mais complexa de se responder. AUERBACH, Erich. Mimesis: A Representação da Realidade na Literatura Ocidental. São Paulo: Editora Perspectiva, 4ª Ed., 2001, p. 234.
} 
lícito recorrer-se a uma fonte extra-textual a fim de ampliar e aprofundar a compreensão textual.

Adiante-se que um aspecto complicador surgiria diante de uma resposta positiva às seguintes questões: até que ponto extrair de Gregório de Tours este contexto jurídico, político e social, que ele, de fato, não expôs, até que ponto isto não seria promover a explosão de seu estilo, até que ponto não seria retirar a sua escrita dos quadros em que ela, faticamente, concretizou-se? Essas são questões que emergem da leitura de Mimesis e de uma apreciação mais detida da controvérsia entre Gabriel Monod e Fustel de Coulanges.

Seguindo as pistas deixadas por Auerbach, percebece-se que a controvérsia teve início com a publicação do artigo de Monod Les Aventures de Sichaire ${ }^{59}$ no qual Monod apresenta um comentário sobre os dois trechos em que Gregório de Tours relata a sangrenta luta que se travou entre Sicário e Cramnesindo, dois francos que gravitavam ao redor da circunscrição eclesiástica de Gregório, o que o fez tomar importante parte no ocorrido e, o que mais interessa aqui, foi decisivo para que ele tenha narrado o episódio em sua História dos Francos. Porém, e este é um ponto central do desentendimento, Monod fornece detalhes que não poderiam ser extraídos da principal fonte histórica sobre as tais desordens cívicas em Tours: o próprio livro de Gregório de Tours. A estratégia de Monod é a de ler a História dos Francos em paralelo com outros documentos ou informações disponíveis sobre a época dos fatos. Por esta razão, ao comentar passagens um tanto confusas de Gregório, Monod utiliza outras informações extra textuais que o auxiliariam a tornar mais claro o relato do bispo de Tours sobre o corrido em sua cidade. Este comentário de aproximação ou comparação (rapprochmente e comparaison, respectivamente), como o denomina algo pejorativamente Coulanges, toma a Lex Salica, uma codificação jurídica reputada como o direito vigente entre os Francos do período, para aclarar certas passagens da História dos Francos. Deste modo, Monod chega a detalhamentos relevantes para a compreensão das circunstâncias históricas. Exemplo disso é não apenas sua tentativa de quantificar os valores das compensações que as partes teriam sido condenadas a pagar, mas também sua facilidade em discorrer sobre o estatuto jurídico dos escravos na sociedade franca do século VI. São estes e muitos outros os aspectos que Monod apresenta, mas que são sistematicamente refutados por Coulanges por,

\footnotetext{
${ }^{59}$ MONOD, Gabriel. "Les Aventures de Sichaire" in Revue Historique, 11eme Année, Tome 31 e 1886, pp. 259290.
} 
segundo ele, não possuírem embasamento histórico no texto de Gregório e não passarem de conjecturas precipitadas desprovidas de adequada fundamentação histórica ${ }^{60}$. Não seria impensável formular o questionamento de Coulanges a Monod da seguinte forma: como se pode presumir a aplicação da Lex Salica ao caso sem que Gregório de Tours - a fonte por excelência - tenha afirmado que o foi. Inegavelmente, trata-se de uma crítica pertinente ${ }^{61}$.

De fato, a discordância entre os dois historiadores franceses parece residir especificamente nesta possibilidade de se escrever história valendo-se de múltiplas e concomitantes fontes. Formulado de outro modo, é possível que informações oriundas de fontes diversas preencham as lacunas existentes em um documento histórico pouco claro? Coulanges sublinha principalmente os perigos e imprecisões decorrentes dessa técnica que aproxima documentos que não necessariamente convergem, que não necessariamente se referem ao mesmo período, pessoas e instituições. É sintomática, neste sentido, a frase que abre o seu texto que polemiza com Monod:

"Il n'est pas besoin de dire que la vérité historique ne se trouve que dans les documents. On sait cela en France depuis quatre siècles. Il n'est même pas besoin d'ajouter que c'est par l'analyse exacte de chaque document que l'historien doit commencer son travail., 62

Trata-se de uma forte objeção à maneira como procedeu Monod ao comentar o documento histórico à luz do que seria o direito vigente à época dos fatos. A crítica de Coulanges ao trabalho de Monod se dirige justamente ao fato de este ter tomado como verdadeiro e inquestionável que a Lex Salica desempenhou um papel relevante na solução da disputa envolvendo Sicário e Cramnesindo. O que não seria de todo incontroverso quando se analisa o fragmento que apenas menciona lex, não lhe acrescentando a qualificação, que, aliás, teria sido capaz de localizar o leitor quanto a que lei é feita referência. Pois é justamente esta

\footnotetext{
${ }^{60}$ Como se disse, ao que tudo indica, a preocupação central de Coulanges era combater uma forma específica de fazer história e que se contrapunha à sua, que era a análise. Assim ele a define, logo no início: "L'analyse d'un texte, tel qu'une charte, un article de loi, une lettre, un récit d'un historien, une simple phrase, consiste à examiner par le menu chacun des éléments de ce texte, à établir le sens de chaque mot, à dégager la vraie pensée de celui qui a écrit." FUSTEL DE COULANGES, Numa Denis. "L'Analyse des Textes Historiques" in Revue des Questions Historiques, 21eme Année, Tome 41 e , 1887, p. 5.

${ }^{61}$ O próprio Monod aceitou algumas das críticas e rebateu outras em MONOD, Gabriel."Lettre de M. G. Monod en réponse à l'article de M. Fustel de Coulanges intitulé 'De l'analyse des textes historiques." Revue des questions historiques, Tome 41, 1887, pp. 540-48.

${ }^{62}$ FUSTEL DE COULANGES, Numa Denis. "L'Analyse des Textes Historiques" in Revue des Questions Historiques, 21ere Année, Tome 41 e , 1887, p. 5.
} 
passagem que Coulanges cita para questionar aquilo que Monod havia pressuposto. Porquanto, segundo Coulanges, quando se fala em lex e suas declinações nada nos levaria a crer, par l'analyse exacte de chaque document, que se trata da lei sálica:

“Quand Grégoire dit qu'en prononçant une composition on agissait contrairement aux lois, ce n'est certainement pas de la loi salique qu'il veut parler. Aussi ne dit-il pas contra legem salicam; il dit contra leges. Prendre leges pour legem salicam est une inexactude d'autant plus grave que, dans la langue mérovingienne, le mot lex a une acception fort différente quand il est employé au singulier ou quand il est employé au pluriel. „63

Monod é criticado em muitos aspectos, todos eles, contudo, referem-se a este procedimento de pressupor como certa a conexão entre dois documentos históricos e, a partir disso, comentar o trecho de Gregório de Tours completando-o, suprindo-lhe as lacunas, por meio de outros documentos. É desta maneira, por exemplo, que Monod é capaz de quantificar as compensações que teriam sido arbitradas entre as partes. A partir de dispositivos da lei sálica que determinam a quantia a ser paga pelo homicídio de um franco (200 sous d'or ${ }^{64}$ ) ele chega a fazer a atualização do valor para o ano de 1886 e afirma que a quantia a que foi condenado Sicário seria o equivalente a 228.870 francos de $1886^{65}$.

Em grande medida, as ilações feitas por Monod não são de todo despropositadas como nos leva a crer, em algumas passagens, o próprio Coulanges. No entanto, a tentativa de tornar Gregório de Tours mais claro possui uma relação direta com a forma como Gregório compôs sua narrativa, pois aos olhos contemporâneos ela é frequentemente considerada obscura.

A forma como escreve Gregório de Tours, porém, não é de todo despropositada ou aleatória. Ao falar lei devia ele estar tão profundamente envolvido pelo mundo em que vivia que uma menção específica a qual lei específica ele se referia talvez fosse desprovida de sentido. Da mesma maneira que esta ausência deu origem a grande parte da controvérsia entre os historiadores franceses, também reflete ela muito da concepção do próprio Gregório acerca de seu mundo e da adequada maneira de representá-lo. Ao que tudo indica, seu público teria

\footnotetext{
${ }^{63}$ Id. p. 27.

${ }^{64}$ MONOD, op. cit. pp. 267-8 n.1. O trecho que Monod cita como referência é o Título XLI $\S 1^{\circ}$ da Lex Salica: De homicidiis ingenuorum. Uma tradução feita pelo Professor Herman Nehlsen da Ludwig Maximilians Universität para o seu curso sobre História do Direito Penal (Strafrechtsgeschichte) possui a seguinte forma: "Von Totschlägen an Freien. Wenn einer aber einen freien Franken oder sonstigen Germanen, der nach salfränkischem Gesetz lebt, tötet, werde er, dem es nachgewiesen wird, - gerichtlich "Manngeld" genannt - 8000 Pfennige, die machen 200 Schillinge, zu schulden verurteilt."

${ }^{65}$ MONOD, op. cit. pp. 267.
} 
de estar igualmente envolvido pelas mesmas instituições que o envolviam, de modo a compreender o não dito, captar suas omissões. Na verdade, o que deixou de ser dito pressupõe um leitor capaz de suprir as lacunas do texto com as informações que comporiam o mundo de Gregório, do qual o leitor teria que compartilhar muitos pressupostos a fim de compreender com exatidão o que era narrado.

Pois é exatamente este compartilhamento do mundo de Gregório de Tours que não mais subsistia no final do século XIX, no momento mesmo em que Gabriel Monod decide apresentar seu comentário a escrutínio público. A fim de suprir estas insuficiências que são parte integrante do estilo de Gregório, na medida em que denota a forte ligação que mantém com seu mundo vivido ${ }^{66}$, Monod busca reconstruir este mundo de Gregório com aquilo que pôde recuperar. Intenta Monod, dentre outros aspectos, completar o incompleto de Gregório por meio da passagem de Lex, que consta do texto, a Lex Salica. Esta mera adjetivação explica grande parte da controvérsia, mas não é só ela, pois Monod estende este suprimento das lacunas do texto a diversos aspectos como a suposição de que o nome franco denotaria o grupo humano, race, à qual a pessoa pertence e também se aventura em uma caracterização funcional de termos como pars e amici que pululam no texto de Gregório. Todas estas precipitações que Coulanges aponta em Monod se originam da profunda especificidade do modo de expressão escrito de Gregório de Tours.

O medievalista Martin Heinzelmann contribui, ainda que indiretamente, a este debate no momento em que comenta a posição que o bispo de Tours ocupa na historiografia. Segundo ele, Gregório foi visto em muitos momentos como um repositório de fatos históricos em estado bruto, sendo que se negligenciava o fato de ele ser um historiador, o que implica um tratamento dos fatos e não a sua simples e imediata transmissão ${ }^{67}$.

Existem, contudo, outras hipóteses a respeito do que gera esta falta de consenso em torno de Gregório de Tours e embaralha a exata interpretação dos termos por ele empregados. Uma delas sublinha sua pretensa incapacidade de exprimir e ordenar os fatos por meio do

\footnotetext{
66 “O que narra é o seu próprio, o seu único mundo; não tem outro, e vive nele.” AUERBACH op. cit. p. 78.

67 "Our ignorance of the actual didactic intentions of this author [Gregório de Tours], who as we now know had selected and edited his material in some quite extreme ways, means that this apparently naively presented exemplars have not been adequately explored. Gregory's Histories were used but were neither unsterstood nor made understandable." HEINZELMANN, Martin. Gregory of Tours: History and Society in the Sixth Century. Cambridge: Cambridge University Press, 2001, p. 2. Mais adiante na mesma página Heinzelmann cita a passagem do medievalista John Michael Wallace-Hadrill em que diz que Gregório foi usado, muitas vezes, como "storehouse of information" e esqueceu-se que ele era, também, um historiador com todos os matizes e distorções que esta posição implica.
} 
relato escrito, mas esta incapacidade, paradoxalmente, mantém, em sua linguagem, a atualidade pungente do presente vivido ${ }^{68}$. Em outros termos, parece que o presente em estado bruto, o presente como vivenciado, é transposto a despeito e em razão desta sua insuficiência de linguagem. Se, de fato, Gregório de Tours vivenciava um presente de tal forma intenso que não se via compelido a figurar, por meio de sua linguagem, muitos dos aspectos de seu mundo contemporâneo, então não é de todo infundado que, com o esfacelamento deste seu mundo, muitos séculos depois, tornaram-se de tal forma incertos e vacilantes seus escritos a ponto de suscitar um debate público acirrado como aquele entre Monod e Coulanges. Na verdade, uma interpretação para o tal debate é que ele constitui uma disputa acerca da possibilidade, ou não, da reconstrução deste mundo de Gregório, este mundo por ele vivenciado e que está intimamente ligado à gênese de seu estilo.

Monod, por exemplo, acredita nesta possibilidade e realmente tenta reconstruir os contextos de Gregório. Coulanges, por sua vez, vê com extremo ceticismo esta empreitada, notadamente em função de sua concepção da escrita da história ser sensivelmente menos aberta a estas aproximações e comparações.

Caberia, neste sentido, um questionamento: o que, afinal, separa o mundo de Gregório daquele em que viviam os dois historiadores, por qual motivo não são eles capazes de captar todo este mundo que, pela sua evidência, é subentendido por Gregório? Aparentemente, falta o mundo contemporâneo dos francos aos historiadores, sem este não lhes é dado compreender por completo os escritos de Gregório de Tours.

Porém, ainda é possível enfocar a questão pelo ângulo oposto, isto é, não seria a consciência do século XIX limitada em sua compreensão do mundo de Gregório, mas sim os limites da consciência histórica de Gregório teriam limitado a capacidade figurar seu próprio mundo em sua amplitude, em sua historicidade e em sua problematicidade ${ }^{69}$. O que resta para o século XIX é um quadro estático, confuso e incompleto da realidade franca. Ao intuir esta limitação, Monod busca completar a historicidade do quadro de Gregório, por exemplo, por meio do recurso à Lex Salica. Isto, por sua vez, gera talvez um desencontro considerável na medida em que insere nos problemas de interpretação de Gregório de Tours e sua obra uma

\footnotetext{
68 "Ele não é capaz de apresentar de forma nítida qualquer concatenação de acontecimentos que não seja muito simples. Sua linguagem ordena mal, ou não ordena absolutamente. Mas ela vive no concreto dos acontecimentos, fala junto e dentro dos seres humanos que nela se movimentam.” AUERBACH op. cit. p. 78.

${ }^{69}$ Ou como afirma Auerbach alguns capítulos adiante não há: “(...) uma base que permitisse ordenar, interpretar e representar o mundo todo como realidade.” AUERBACH op. cit. p. 201.
} 
variável também muito complexa: a representação jurídica da realidade, que também tem sua visão limitada pelo estilo jurídico e que também é incapaz de captar um quadro que se movimenta em sua historicidade.

Aparentemente, a tentativa de Monod, ainda que frustrada de acordo com Coulanges, vai nesta direção ao buscar recuperar as pressuposições que permeavam de tal modo o mundo de Gregório de Tours a ponto de ele nem mesmo se dar o trabalho de lhes exprimir. Esta chave de interpretação do autor da História dos Francos está, contudo, muito longe de ser dominante ou consensual. Quando se trata de Gregório de Tours uma opinião corrente tem sido de sua incapacidade de ordenar os fatos e a natureza rude de sua linguagem. A primeira é, em parte, a opinião de Auerbach: “(...) isto, por seu lado, revela que o próprio Gregório é incapaz de ordenar claramente os acontecimentos." ${ }^{, 70}$.

Esta caracterização de Gregório de Tours por Auerbach se difundiu a ponto de, mais de quarenta anos depois da publicação de Mimesis, o historiador Martin Heinzelmann afirmar que o tratamento isolado dado por Auerbach a Gregório de Tours contribuiu para muitos dos problemas das pesquisas em torno do bispo e, além disso, que o capítulo IV de Mimesis deixou uma impressão duradoura de Gregório de Tours aos filólogos, sendo esta, porém, uma má impressão ${ }^{71}$.

Gabriel Monod, por sua vez, também se posiciona acerca da linguagem de Gregório. É dele a caracterização da linguagem do bispo como rude:

"Sans avoir jamais eu la prétention de composer des récits pittoresques ou dramatiques, Grégoire de Tours, rien qu'en racontant tout simplement, dans son rude langage, ce qu'il a vu ou entendu, nous a laissé des tableaux de mœurs d'un relief et d'un coloris incomparable. "72

A rudeza da linguagem, no entanto, é na passagem apenas um aposto, o ponto central seria algo como um hiper realismo de Gregório de Tours, algo como um pretenso relato puro dos fatos, que desconsidera a circunstância de que o ato de escrever é, por si próprio, altamente seletivo e que a exposição da realidade não é uma transposição simples e natural da apreensão do real para a forma escrita. Aliás, a se seguir o argumento contido em Mimesis, a

\footnotetext{
${ }^{70}$ AUERBACH, Erich. Mimesis: A Representação da Realidade na Literatura Ocidental. São Paulo: Editora Perspectiva, $4^{\mathrm{a}}$ Ed., 2001, p. 72.

${ }^{71}$ HEINZELMANN, Martin. Gregory of Tours: History and Society in the Sixth Century. Cambridge: Cambridge University Press, 2001, pp. 59 e 96 (respectivamente).

${ }^{72}$ MONOD op. cit., p. 265.
} 
exposição séria do real-cotidiano seria antes a exceção do que a regra, antes um feito da maior maestria do que conseqüência de um escritor ingênuo e desprovido de aptidões estilísticas. Aliás, esta história da apreensão humana do real, da realidade exposta na literatura, é substancialmente longa e permeada de inflexões, transformações, que se relacionam, embora não de forma determinante, com o evolver religioso, político e cultural do humano.

Uma passagem sobre os limites da exposição da realidade em Boccaccio é capaz de contrapor a algo ingênua concepção de Monod sobre a realidade em Gregório de Tours:

“Justamente nas passagens em que Boccaccio tenta penetrar no campo do problemático ou do trágico, reconhece-se a pouca clareza e a insegurança da sua ideologia, do seu humanismo prematuro. O seu realismo, livre, rico e magistral no domínio dos fenômenos, totalmente natural nos limites do estilo médio, torna-se frouxo e superficial tão logo roça na problemática ou na tragicidade (...) a mundanidade de homens como Boccacio era ainda demasiado insegura e instável para poder oferecer uma base que, como aquela exegese [figural cristã], permitisse ordenar, interpretar e representar o mundo todo como realidade. ${ }^{73}$

Ou seja, de fato, a primeira parte da frase de Monod sobre Gregório de Tours pode ser tida como correta, há nos escritos do bispo aquilo que ele viu e ouviu ${ }^{74}$, porém um quadro dos costumes da sociedade merovíngia, como quer Monod, está muito além dos limites do estilo de Gregório. Aquilo que ele expõe em seus escritos está fatalmente restrito pelos limites de sua capacidade de expressão, pelos limites do cristianismo ${ }^{75}$ e pelos limites de seu mundo, assim como ele, paradoxalmente, o concebe como totalidade: quando pensa estar dizendo tudo, e fidedignamente, está apenas expondo os limites de sua apreensão do real. O quadro de Gregório de Tours é estático e incapaz de apreender o movimento das forças históricas; os incêndios, assassinatos, amputações que ele relata não se encadeiam com qualquer transformação político social, resumem-se ao ímpeto vingativo daqueles francos dignos de

\footnotetext{
${ }^{73}$ AUERBACH op. cit., p. 201.

${ }^{74}$ Isto constitui também uma limitação de seu horizonte: "O seu material limita-se essencialmente àquilo que ele próprio viu." AUERBACH op. cit. p. 73.

${ }_{75}$ Auerbach reduz substancialmente este aspecto, para ele Gregório está aquém de uma percepção profunda do cristianismo, é antes a igreja como instituição concreta e ainda em Tours, isto é, sua visada atinge não mais que os arredores de sua diocese, se aceitarmos a posição de Auerbach: "Ele não possui um ponto de vista político no sentido antigo, e se se quiser falar de algo semelhante na sua obra, tal ponto de vista seria o dos interesses da Igreja. Mas também isto ele enxerga num campo limitado; não é capaz de pensar no todo da Igreja de tal forma que isso surja da sua obra com intensidade; tudo fica circunscrito localmente, tanto material como mentalmente." AUERBACH op. cit. p. 73.
} 
serem figurados em sua narrativa. Obviamente, se ele fosse capaz naquele momento de figurar estes aspectos, o seu estilo, como diz Auerbach em relação a Petrônio, explodiria. O estilo, por sua gênese e estrutura, seria incapaz de assimilar estas novas fórmulas, a figuração desta realidade exposta, suas condições de possibilidade, precisam estar atreladas às próprias condicionantes históricas, sociais e culturais do estilo. Pensar um estilo cuja gênese se daria independentemente de qualquer variável externa à criação literária seria perder a realidade da formação do estilo, seria iludir-se a respeito de uma criação literária fechada em torno de si mesma. É o próprio Auerbach que, ao passar pelo classicismo francês, um ponto culminante da separação de estilos, aponta a relevância do método sociológico para a adequada compreensão do teatro de Racine e sua época:

"Em todo caso, foi [Taine] o primeiro a empregar o método sociológico, indispensável para uma compreensão perspectivo-histórica do grande século. Sem uma visão social não se poderia explicar como o enaltecimento do nível estilístico e os ornatos barrocos da expressão puderam ganhar um tal valor modal e uma tal irradiação numa época que, em tantos sentidos, em tantos âmbitos, filosófica, e científica, política, econômica, e até socialmente, possui um caráter moderno-racionalista, e que até fundamentou, em muitos sentidos, os métodos moderno-racionalistas (...),76

Por todas estas razões, é injustificado analisar Gregório de Tours unicamente com base em critérios que, reiteradamente, apontam-lhe as insuficiências. Não existe uma evolução paulatina do estilo que faz com que Gregório seja uma etapa em direção ao aperfeiçoamento. Como Auerbach deixa claro, a importância de Gregório reside no fato de ser um representante, por um lado, do enfraquecimento da cultura retórica da Antiguidade, da qual se vê libertado para expor os muitas vezes cruéis desdobramentos da vida franca e, por outro, ser um elo entre o latim clássico e as línguas vulgares literárias. O seu latim confuso e matizado, neste sentido, é um representante da ebulição das línguas vulgares que irromperão de um latim como o de Gregório de Tours, quebrando-lhe a moldura:

“A língua vulgar ainda não é um instrumento utilizável literariamente; ela não basta, evidentemente, nem para as mais modestas exigências da expressão literária. Mas já existe,

\footnotetext{
${ }^{76}$ AUERBACH, op. cit., p. 350.
} 
como língua falada, como língua que apreende o real cotidiano, e como tal é perceptível em Gregório."77

Compare-se a nítida diferença do que nos diz Auerbach com a rasa análise de Monod, um tanto laudatória e pouco explicativa:

"Le récit que nous a laissé Grégoire de Tours de ces tragiques événements, qui s'étaient déroulés sous ses yeux, est une des pages les plus vivantes et les plus instructives de l'Historia Francorum, ce livre unique, incomparable dans sa rude sincerité, dans son naïf et éloquent réalisme, sans lequel le monde barbare serait mort et à jamais fermé et mouet pour nous. "78

Todos estes aspectos são elementos para a análise da específica forma de representação em Gregório de Tours, o comentário de Monod segue um caminho que se poderia chamar de uma troca da realidade exposta pela exposição da realidade. A partir do que ele escreve, há uma aparente realidade franca inscrita na obra de Gregório, isto é, pode-se apreender o mundo franco mediante a leitura da História dos Francos, pois que haveria ali a exposição da realidade (Darstellung der Wirklichkeit). Sob esta visão, a realidade parece esburacada e lacunosa, ela não emerge daqueles escritos. Esta pretensa incompletude que tanto se sublinha e que tanto se procura suprir em Gregório, talvez seja justamente uma confusão em torno da ideia de exposição da realidade e realidade exposta (dargestellte Wirklichkeit) ${ }^{79}$. Se se analisa a obra do bispo buscando nela a exposição da realidade, então certamente o sentimento de insuficiência e incompletude será inevitável. A rigor, temos de procurar aquela realidade que é exposta por meio da obra, aquela que existe intra-literariamente, ainda que a investigação das variáveis políticas, sociais e religiosas da criação literária seja um caminho válido e elucidativo.

Ainda que não tenha se posicionado neste sentido, Mimesis é útil para melhor se entender as discussões entre Monod e Coulanges. Ambos os franceses pareciam ler Gregório de Tours como fonte histórica em busca da reconstrução de uma pretensa verdade histórica objetiva. No entanto, esta estratégia, embora factível, esbarra em um problema relevante, as vicissitudes do estilo do autor, que é a sua peculiar forma de apresentar uma realidade exposta. Ou seja, ao passar pelo filtro da criação literária aquela realidade hipotética se apresenta

\footnotetext{
${ }^{77}$ AUERBACH op. cit. p. 82.

${ }^{78}$ MONOD op. cit. p. 289.

${ }^{79}$ WAIZBORT, Leopoldo. "Erich Auerbach Sociólogo" in Tempo Social, v. 16, n. 1, 2004, p. 85.
} 
profundamente marcada pelas percepções do autor. Não se quer com isto dizer que o mecanismo de percepção seja algo independente de seu entorno, há indiscutivelmente uma criação social das percepções de uma época; o que se quer dizer é: após a apreensão, cria-se um real, mas um real inserido no processo de criação literária, que não pode ser pensado despregado desse processo. Deste modo, a análise do realismo em Gregório de Tours não é a análise do real no século VI, mas sim a análise de uma específica criação de uma realidade interna à obra de Gregório de Tours. Portanto, na forma literária o que se encontra é uma realidade enviesada, porém isto não significa dizer que existam fontes não enviesadas, todas o são na medida em que são filtradas por um determinado estilo.

\section{Post Scriptum}

A abertura contida no Mimesis é curta e puco relata além da indicação precisa da fonte sobre a questão Monod/Coulanges. Na verdade, a remissão é útil como forma de desincumbir maiores explicações sobre o ponto e permitir que o argumento siga adiante liberado de maiores polêmicas em torno do direito na obra de Gregório de Tours. Da mesma forma, Auerbach se abstém de comentar os limites e possibilidades de se proceder a uma interpretação do fragmento à luz da Lex Salica, ou de qualquer outro direito que seria pretensamente vigente entre os francos da época de Gregório. Ele, aliás, incorpora a polêmica e não toma posição nela quando diz: "Durante o segundo processo judicial ou conciliatório (...) ${ }^{\natural 80}$, ou seja, independentemente se Monod ou Coulanges estavam certos, Auerbach prossegue com o argumento. O direito, apesar disso, é uma presença constante e marginal em Auerbach. Direito público, direito natural são termos que aparecem em Mimesis, mas não desempenham um papel relevante. Esta relevância secundária talvez seja explicável à luz da própria trajetória de Auerbach. Seus estudos jurídicos na juventude não o levaram a ser um jurista, mas aparentemente marcaram-no a ponto de direito e jurídico serem termos presentes em sua obra para aqueles que a leem em busca justamente de tais termos. Seria forçar o argumento, contudo, dizer que estas menções passageiras teriam um papel essencial, pois elas aproximam-se antes de uma reminiscência de juventude, algo distante e secundário. Apesar disso, as pistas que Auerbach deixa em seu texto, como esta sobre o debate entre Monod e

\footnotetext{
${ }^{80}$ AUERBACH op. cit. p. 72.
} 
Coulanges, constituem entradas para um debate subjacente, mas possível, acerca das formas de uma realidade exposta por meio do direito. Também esta, aliás, seria uma das facetas da criatividade humana e, nesta qualidade, proveria uma chave de compreensão para todas as outras facetas no mesmo estágio ${ }^{81}$. Inquestionavelmente, o direito não é a faceta privilegiada por Auerbach, salvo talvez em sua tese jurídica de doutorado ${ }^{82}$. Para os interessados no assunto, porém, as pequenas aberturas podem levar a debates profundos sobre o direito, embora não tenha sido esta sua preocupação central.

Para um leitor jurídico, à primeira mirada, Mimesis parece aproximar-se de uma efusão de referências histórico-literárias, cuja ligação não é prontamente apreensível a alguém estranho ao círculo de cultura de Auerbach. Compreender, por exemplo, as alterações na percepção que preparam as condições de possibilidade do teatro cristão medieval será, certamente, uma tarefa árdua no caso de a existência mesma do teatro cristão ser algo previamente desconhecido. Neste caso, o desconhecimento implica que nada se saiba sobre sua gênese e, portanto, qualquer relação que se pretenda estabelecer entre aquele teatro e seus antecessores, entre essa forma literária e o Cristianismo, tudo isto se torna bem menos claro e substancialmente menos passível de contraposição e questionamento. Simplesmente não há, no arcabouço histórico-lietarário deste leitor hipotético, o que relacionar com o que é exposto.

Certamente, Auerbach esperava mais de seu leitor, esperava, no mínimo, que ele fosse familiar com os episódios do Antigo Testamento e, deste modo, não titubeasse para lembrar-se da resposta de Abrahão a Isaac. Talvez mesmo não concebesse que alguém não o soubesse. Uma outra hipótese, no entanto, é que, ao fazer estes apelos ao leitor, estaria instando-o a adentrar este seu universo histórico-intelectual, tentando promover uma forma de identificação ou cumplicidade.

Estas, porém, não passam de hipóteses. Uma verdade é que Auerbach esparsamente encontrou, nos longos anos que nos separam da publicação do livro, leitores aptos a dialogar, em toda a sua amplitude, com os assuntos tratados, com as línguas que se apresentam nos trechos selecionados e com os debates históricos, literários e sociológicos que perpassam todo

\footnotetext{
${ }^{81}$ Esta é uma paráfrase de um trecho em que o direito é citado nominalmente. AUERBACH, Erich. Literary Language and its Public in Late Latin Antiquity and in the Middle Ages. Princeton: Princeton University Press, 1965 , p. 8

${ }^{82}$ Trata-se de sua "juristische Dissertation" de 1913 intitulada Die Teilnahme in den Vorarbeiten zu einem neuen Strafgesetzbuch cuja leitura deve ser extremamente interessante em busca de sinais da mudança de direção que se operou em sua vida e de como sua virada literária estava latente já nos seus estudos jurídicos. Cf. WAIZBORT op. cit. p. 78.
} 
o livro. Não que haja impossibilidade, porém se trata de algo não corriqueiro. Por esta razão, uma modalidade de leitura freqüente de Mimesis acaba por ser seletiva, pinça-se um trecho ou um capítulo de modo que este se torne compreensível a partir de um percurso que se inicia fora do livro, quase que como uma reconstrução do debate que lhe é subjacente, e chega a Mimesis para que então este se apresente de forma mais compreensível.

A questão entre Gregório de Tours, a Lex Salica, Gabriel Monod e Fustel de Coulanges é ilustrativa deste aspecto. Por qual razão existe a menção? Sabe-se que Auerbach escreveu o livro em Istambul, sem acesso a grandes arquivos universitários, o que ele admite en passant no Epílogo ${ }^{83}$, não se daria ao trabalho de fazer uma referência inútil. Ao seguir esta pista, um leitor se depara com um debate que pode, ao mesmo tempo, ser lido em paralelo ao argumento central de Mimesis, como pode ser somente um debate sobre a história do direito na Idade Média.

Em suma, este caminho Mimesis, Monod/Coulanges, história da realidade exposta por meio do direito é para ser trilhado por aqueles que por isso se interessam. A etapa do Mimesis nesta tríade não é desprezível, ao contrário, trata-se de uma passagem que outorga um sentido muito profundo a este todo.

\footnotetext{
${ }^{83}$ AUERBACH, op. cit. p. 502.
} 


\section{A Desapropriação da Várzea do Rio Pinheiros}

O que existe é apenas o reconhecimento do direito de desapropriação, outorgado indeterminadamente, - já que não é curial admittir-se que uma empreza particular (a apellada) ficasse autorisada a retirar do dominio privado alheio, segundo o seu critério ou seguindo o seu capricho, tudo o que se encontrasse na folha do mappa do Estado [de São Paulo] $(\ldots)^{84}$

O trecho acima foi extraído de uma apelação patrocinada pelo advogado João Sampaio em ação originalmente proposta contra uma desapropriação levada a cabo pela Light em Cubatão e cujas peças do advogado foram posteriormente publicadas em livro que percorre alguns dos registros jurídicos do caso. Essa é uma pequena amostra das circunstâncias sob as quais a Companhia Light agia e os ânimos que, de uma forma ou de outra, geravam as desapropriações por ela promovidas. A atividade expropriatória da empresa já é constatada em um registro legal no qual o Estado de São Paulo estatui que a Companhia Light "gosará (sic) do direito de desapropriação" remontando este trecho à Lei Estadual n. 677 do ano de 1899, o mesmo em que fora publicado o Decreto Federal 3.349 de 1899 que autorizou a companhia de capital canadense a iniciar suas atividades no Brasil.

Por se tratar, desde o início, de uma empresa prestadora de serviços públicos, seria de se esperar que a atividade da Light ocorresse em estreita cooperação com o Poder Público. Essa ligação próxima teve início em data coincidente com o estabelecimento da companhia no país, ganhando esta inclusive a prerrogativa de promover desapropriações. A colocação feita pelo advogado João Sampaio em seu arrazoado não era, consequentemente, desprovida de fundamento, porém a ação da Companhia Light estava inserida em um contexto legal, político e econômico mais amplo e mais profundamente imbricado com a atuação administrativa do Estado nos primeiros decênios do século XX do que antevia o advogado.

Dessa relação intensa que houve entre a Light e os serviços públicos, principalmente em São Paulo e no Rio de Janeiro, um dos mais curiosos - e controversos - produtos provavelmente foi o saneamento da Várzea do Rio Pinheiros em São Paulo e a inversão de seu curso. Obra pública de grande porte, ela foi gestada e executada ao longo de mais de vinte

\footnotetext{
${ }^{84}$ Grafia original de SAMPAIO, João. Acerca de uma desapropriação da Light \& Power. São Paulo: R. dos Tribunaes, 1936, p. 14.
} 
anos e seus desdobramentos jurídicos apenas foram totalmente deslindados com o acórdão do Supremo Tribunal Federal no Recurso Extraordinário 37.081 no ano de 1968. Além das controvérsias jurídicas, a retificação fluvial e a inversão de seu curso constituíram um evento de grande importância para a definição do espaço urbano em São Paulo e para o direcionamento de seu crescimento ao longo das vias e bairros construídos às margens do Pinheiros.

Do ponto de vista técnico-hidrológico ${ }^{85}$, a retificação do Rio Pinheiros visava alterar suas características de rio de várzea, marcado que era pelos meandros intermitentes, para uma configuração física mais retilínea e perene. Esse novo formato decorrente da intervenção humana teria duas consequências fundamentais do ponto de vista da futura configuração urbana em São Paulo: (i) permitiria a ocupação das várzeas, que não mais estariam sujeitas às intermitências de cheias periódicas e alterações de curso do rio; e (ii) permitiria que, futuramente, fosse possível estruturar o viário urbano por meio de pistas expressas nas marginais.

Um outro aspecto relevante das grandes transformações pelas quais passou o Rio Pinheiros a partir de finais dos anos 1930 foi a inversão de seu curso, possibilitado pela construção da estação elevatória de Traição - assim nomeada em virtude de um córrego próximo de mesmo nome. A inversão do curso do rio tinha por fim imediato aumentar a capacidade de geração da hidrelétrica Henry Borden, em Cubatão, de cuja desapropriação, aliás, o advogado João Sampaio se queixava em nome de seu cliente que perdera a propriedade em favor das obras de ampliação da geradora de eletricidade da Light no litoral paulista. Observa-se, assim, que as intervenções fluviais respondiam a mais de uma necessidade e faziam parte de um plano integrado para a estruturação urbana, produção de energia elétrica e abastecimento de água da capital e dos arredores.

Em vista do vultuoso projeto que se queria implantar no Pinheiros e com o fito de concretizar essa transformação urbana, o Governo do Estado de São Paulo deu início à formatação jurídica do empreendimento com a Lei 2.249/1927 que assim dispôs:

\footnotetext{
${ }^{85}$ As explicações são baseadas no relato de Odette Seabra, Professora do Departamento de Geografia da Universidade de São Paulo. Cf. SEABRA, Odette C. L. Os Meandros dos Rios nos Meandros do Poder: Tietê e Pinheiros valorização dos rios e das várzeas na cidade de São Paulo. São Paulo: Departamento de Geografia da Faculdade de Filosofia, Letras e Ciências Humanas da Universidade de São Paulo, 1987 (Tese de Doutorado), pp. 3-24.
} 
"Artigo 1." - Fica o Poder Executivo autorisado a conceder á «The São Paulo Tramway, Light and Power Company Limited» nas condições que julgar mais convenientes ao interesse publico, o direito de:

(omissis)

b) canalisar, alargar, rectificar e aprofundar os leitos dos rios Pinheiros e seus affluentes Grande e Guarapiranga á jusante das respectivas barragens, nos municipios de Santo Amaro e da Capital, drenando, saneando e beneficiando assim Os terrenos situados nas respectivas zonas inundaveis;" (Grafia conforme o original)

O próximo passo foi a celebração de um contrato entre a Companhia Light e o Governo estadual cujos termos foram aprovados pelo Decreto 4.487/1928. A disposição fulcral do contrato ficou inscrita na seguinte cláusula:

"XX - Ficam declarados de necessidade publica, para serem desapropriados pela Companhia, na forma da legislação em vigor, os terrenos situados na zona affettada pelas enchentes dos rios Pinheiros e seus affluentes, Grande e Guarapiranga, e que forem beneficiados em virtude da canalisação desses rios. Antes, porém, de realisar as obras de canalisação do rio Pinheiros e seus affluentes, deverá a Companhia submetter á approvação do Governo a planta da área a desapropriar, com indicação dos seus limites, bem como o projecto detalhado das obras de saneamento ou dos beneficios a realisar nessa área. Realisados nesses terrenos os benefícios necessarios, deverá a Companhia vendel-os, respeitados os direitos dos ex proprietarios, na forma da legislação vigente." (Grafia conforme o original)

Ou seja, em consonância com as regras que haviam sido criadas para a retificação do Rio Pinheiros, a Companhia Light se incumbiria de realizar, sob supervisão do governo, a obra pública e também as desapropriações que seriam, ao mesmo tempo, meio necessário à realização do melhoramento público e pagamento pelo contrato administrativo que se celebrava. Nota-se que a forma como a empresa se remuneraria pela obra estava estreitamente ligada à consecução da mesma. Isso porque os imóveis desapropriados às margens do rio só teriam seu valor majorado se as cheias a que estiveram até então sujeitos fossem efetivamente remediadas. Dessa forma, a Light haveria de terminar a obra para então poder vender os imóveis resultantes dos melhoramentos e recuperaria seu investimento pela diferença entre o valor pago na desapropriação e aquele recebido pela revenda dos imóveis. Havia, contudo, um 
outro benefício lateral da obra, aquele decorrente do aumento de capacidade de geração da usina hidroelétrica em Cubatão que teria seu potencial majorado pela reversão do rio.

É esse mecanismo de remuneração, com efeito, que vemos concretizar-se no decreto do então interventor federal em São Paulo, Adhemar de Barros, que dispõe ser a titularidade dos imóveis desapropriados pertencente à empresa como retribuição pela obra pública executada (Decreto 9.380/1938):

"Artigo 1." - Os leitos antigos dos rios Pinheiros e seus afluentes Grande $e$ Guarapiranga, desocupados pela retificação canalização e alargamento dos respectivos cursos, a que está procedendo The São Paulo Tramway Light e Power Company Limited, por força do contrato de 21 de novembro de 1928 entre o Estado e ela, nos têrmos da lei n. 2.249 de 27 de dezembro do 1927, e decreto n. 4 487, de 9 de novembro de 1928, passam a pertencer-lhe, como expropriante dos terrenos necessários a abertura dos novos álveos, em compensação das despesas da expropriação e das obras concedidas e contratadas."

Ou seja, o acordo que fora firmado por meio de diversos instrumentos - contratos, leis e decretos - era o de que caberia à concessionária de serviço público realizar a obra e o financiamento desta não seria feito com o uso direto do caixa do Estado de São Paulo, mas sim por meio da venda dos imóveis beneficiados pela obra pública. Isso porque, ao sanear as várzeas, aterrar o antigo leito e retificar o curso do rio, restaria uma grande quantidade de imóveis aptos à ocupação às margens do rio Pinheiros. Tais imóveis poderiam ser revendidos e a receita oriunda da venda remuneraria as obras civis.

Um ponto sensível do projeto era o de se fixar a amplitude das áreas a serem expropriadas, que não haviam sido fixadas a priori. Essa determinação dos limites fundiários que passariam a pertencer à Light seria feita por meio do ponto que atingisse uma das cheias periódicas que se abatiam sobre o rio e faziam suas margens transbordar. O critério, seria, grosso modo, tantas áreas quanto forem as atingidas pelas cheias, tais seriam objeto de desapropriação pois elas as beneficiárias do saneamento.

Tendo-se em vista que o contrato celebrado com a Light havia tido seus termos aprovados pelo Decreto estadual n. 4.487/1928 e em fevereiro de 1929 ocorreu na cidade de 
São Paulo uma enchente de grandes dimensões foi esta, afinal, a utilizada como critério para demarcação dos limites da futura desapropriação ${ }^{86}$.

No entanto, o acima descrito constitui apenas uma das facetas do acontecimento. Há outra visão, sensivelmente distinta, do ocorrido e que foi sintomaticamente nomeada por Odette Seabra como "o esbulho da Light". Segundo essa leitura, as relações entre o governo de São Paulo e a companhia canadense tinham por fim a apropriação das terras ao longo do rio para a realização de vultosos negócios imobiliários e aumento do potencial hidráulico da bacia para o aumento da produção e abastecimento de eletricidade, atividade altamente rentável à Light. Isso, segundo essa visão, seria feito em detrimento de outros interesses que estavam em jogo, mas subrepresentados, como o das populações ribeirinhas e outros grupos que desenvolviam uma série de atividades estreitamente ligadas ao rio de várzea.

A percepção de Odette Seabra, ex post facto, é a de que o processo de escolha e a condução das mudanças no rio foram feitos de modo a não contemplar os interesses dos pequenos proprietários de imóveis às margens do rio, dos barqueiros que o utilizavam para pesca e transporte e daqueles que retiravam areia e pedregulhos do leito do rio como forma de sustento. Todos esses interesses teriam sido negligenciados na estruturação de uma política de transfiguração urbana que se gestava e que pautaria fortemente o desenvolvimento e o crescimento urbano de São Paulo.

Após discorrer brevemente sobre o papel que o rio tinha para as comunidades ribeirinhas do Pinheiros, Seabra resume os interesses que, ao final, influíram decisivamente na execução do projeto:

"De parte da Companhia [Light] as alterações dos projetos visaram sempre a um aproveitamento progressivo das águas do Tietê, para aumentar a capacidade de geração em Cubatão. Ao poder público interessou alterações que visaram a inserção das várzeas no sistema de circulação e transporte. ${ }^{, 87}$

Por falta de registros claros, não se pode dizer ao certo por qual razão o Estado de São Paulo decidiu encarregar a Light de realizar a obra ao invés de fazê-lo diretamente, promovendo ele mesmo as desapropriações e os melhoramentos públicos necessários.

\footnotetext{
${ }^{86}$ Há na Rua Porto Seguro, localizada no Bairro de Ponte Pequena, uma pequena placa de bronze com a inscrição "Nível da enchente de 1929”. Esse marco que hoje está catalogado pelo Departamento do Patrimônio Histórico foi um dos pontos utilizados para a determinação da área expropriada às margens do rio.

${ }^{87}$ SEABRA, op. cit., p. 246.
} 
Possivelmente por falta de caixa ou por baixa capacidade administrativa e executiva para a concretização de obra de relevo. Os registros não são claros a esse respeito, mas ainda de acordo com o relato de Seabra, caberia ter em mente que parte significativa dos planos de melhoria nos serviços públicos da cidade eram gestados não junto à administração pública, mas sim na própria companhia. É por essa razão, por exemplo, que o engenheiro Asa White Kenney Billings teve um papel tão importante em planejar e executar os projetos de aumento do potencial energético em São Paulo e aqueles de alteração das características hidrológicas da cidade $^{88}$.

Seria, de fato, difícil pensar o espaço urbano em São Paulo, seu abastecimento de água e energia, sem as intervenções da Light nos rios. Além disso, seria ao que tudo indica ingênuo desconsiderar seu papel na estrutura fundiária, pois, segundo cálculos apresentados por Seabra, a Light se tornou proprietária de um estoque de terras que equivaliam a 21 milhões de metros quadrados ${ }^{89}$. Esse montante não é nada desprezível se for considerado que boa parte deles passou a ser apto à utilização apenas após as obras da empresa no rio, ou seja, era uma criação de espaço antes relegado a outros usos. Em outros termos, uma quantidade significativa de terras pôde ser integrada à cidade após o término da retificação e do aterramento do antigo leito do rio.

Se essa mudança pode ser vista como um grande avanço civilizador, tônica de um discurso muito caro à própria Light $^{90}$, não se pode descurar, porém, como se colocou anteriormente, que existem relatos destoantes a essa narrativa positiva dos fatos. Veja-se, por exemplo, o relato denúncia que Nicolau Sevcenko faz da enchente de 1929 e seu contexto a partir de fontes jornalísticas e historiográficas da época:

"Mas o aspecto sobremodo ominoso por trás das inundações apontava para a responsabilidade decisiva que sobre elas tinham os interesses acumpliciados da Light e das autoridades locais e federais. Para garantir a máxima produtividade do seu complexo hidrelétrico de Cubatão, a Light precisava assumir o controle total dos regimes das águas da bacia do alto Tietê até o Pinheiros. (...) A catastrófica enchente de 1929, com seu pavoroso

\footnotetext{
${ }^{88}$ Cf. ACKERMAN, Adolph J. Billings and Water Power in Brazil: a short biography of Asa White Kenney Billings. New York: American Society of Civil Engineers, 1953.

${ }^{89}$ SEABRA, op. cit., p. 241.

${ }^{90}$ Veja-se, por exemplo, o título do livro que deixa transparecer a ideia: MCDOWALL, Duncan. Light: A História da Empresa que modernizou o Brasil. São Paulo: Ediouro, 2008.
} 
cortejo de desgraças e prejuízos, demonstrou todo o alcance patético dessa trama entre a ganância, a irresponsabilidade e a indiferença criminosa."

A retórica do progresso técnico e de novos patamares civilizatórios pretensamente trazidos pela Light não foram unânimes. Por essa razão, torna-se ainda mais relevante a busca por relatos da enchente de 1929 em razão de ter sido ela a responsável pela delimitação do limite das desapropriações. Não existe uma opinião inconteste acerca dos fatores naturais e humanos que podem ter causado a cheia de 1929. Odette Seabra analisou os dados pluviométricos disponíveis para São Paulo entre dezembro de 1928 e fevereiro de $1929^{92}$. Os dados - talvez o ponto mais neutro nessa discussão - mostram que houve um pico de precipitações aferidos nos pontos de medição instalados na Luz e na Avenida Paulista, mas as proporções da enchente, pelos relatos jornalísticos da época, foram desproporcionais à quantidade de chuva ${ }^{93}$.

Desde aquele momento, afirmava-se possuir a Light o controle da vazão da bacia do Tietê e poder, pela abertura e fechamento das comportas, alterar a vazão dos rios. Aliado a isso, não resta dúvidas que a magnitude da cheia poderia aumentar a área a ser desapropriada, circunstância que certamente contribuiria para que a Light pudesse melhor se remunerar com a revenda dos imóveis após o término dos trabalhos no rio Pinheiros. Por ser complexa qualquer afirmação acerca da responsabilidade direta da empresa nos fatos, por faltarem evidências, o que melhor parece caber é a contextualização do que estava, então, em jogo. Concretamente, quanto maior a cheia tão maior seria a área de que se apropriaria a Light, isso é fato. Não obstante isso, não parece que a empresa canadense agia sem limitações e contestações. Houve, por exemplo, contraposições não desprezíveis da Prefeitura de São Paulo, que possuía glebas próximas ao rio, sobre qual deveria ser a cheia a contar para a delimitação da expropriação. Isso porque, nos documentos legais a que se teve acesso, não há uma definição inconteste de qual ano de cheia seria utilizado para a demarcação, por essa razão, em tese, pode-se pensar que uma maneira de ler o contexto - certamente, não a única - seria a de que a empresa, diante dos fatos, sustentou aquele ano como o da delimitação, visto que o contrato com o Estado de São Paulo fora aprovado no ano anterior.

\footnotetext{
${ }^{91}$ SEVCENKO, Nicolau. Orfeu Extático na Metrópole: São Paulo sociedade e cultura nos frementes anos 20. São Paulo: Cia. Das Letras, 1992, p. 134.

${ }^{92}$ SEABRA, op. cit., pp. 174-5 e 194-5.

${ }^{93}$ SEABRA, op. cit., p. 177-89. Trata-se das reportagens publicada n'O Estado de São Paulo e na Folha da Manhã entre os dias 16 e 17 de fevereiro de 1929.
} 
Segundo essa visão, que se não é neutra ao menos parece equidistante, a empresa teria se valido de uma situação anômala para melhorar sua posição, porquanto num ambiente de incerteza e indefinição melhor seria advogar pela maior extensão possível derivada de uma enchente que fugiu ao ordinário. Se houve manipulação das comportas, será difícil determinar, mas indubitavelmente a Light tinha incentivos para fazê-lo, ainda que pudesse sofrer contestações do poder político e a ira da sociedade civil para a qual, afinal, prestava o serviço, não se negligenciando a realidade de que o fazia em regime de monopólio legal.

Feitos esses comentários acerca da enchente, cabe dizer que estavam, para o bem ou para o mal, definidos os limites da desapropriação, porém restava ainda entabular as tratativas para a sua efetivação. Embora as margens do Pinheiros sofressem intermitências anuais, elas não eram de todo desertas, já havia povoamento e proprietários, grandes e pequenos. Dentre os grandes proprietários de imóveis estavam a Companhia Cidade Jardim, a Companhia City, a Prefeitura de São Paulo e o antigo Esporte Clube Germânia (depois Esporte Clube Pinheiros). Com cada um à sua maneira, a Companhia Light realizou acordos com parte significativa desses proprietários, notadamente por meio da doação à Light de terrenos na área, o que, em consenso com a empresa, evitaria a desapropriação integral dos imóveis. Tais doações eram feitas para compensar a empresa canadense dos gastos com as obras no rio e, pelo lado do doador, para evitar que se iniciasse um longo processo judicial de desapropriação.

Segundo um relato de 1951 do então Consultor Jurídico da Light, Eurico Sodré, o acervo imobiliário da Light era fruto de:

1. Aquisição anterior à concessão e à obra;

2. Doação de antigos proprietários como retribuição pela obra (caso da Companhia Cidade Jardim, Companhia City, etc);

3. Aquisição por compra e venda, independente da desapropriação;

4. Acessão pelas obras de drenagem (antigo leito do rio);

5. Aquisição nos termos do Decreto 4.487/1928 com renúncia ao direito de retrocessão;

6. Desapropriação amigável;

7. Desapropriação judicial; e

8. Aquisição, mantido o direito de retrocessão ${ }^{94}$.

\footnotetext{
${ }^{94}$ Documento n $^{\circ}$ DLS 4.956, 11.05.1951, Dr. Eurico Sodré. Citado por SEABRA, op. cit., pp. 241-2.
} 
Constata-se, portanto, que a situação fundiária decorrente da decretação de utilidade e necessidade pública dos bens era sensivelmente mais complexa que uma desapropriação generalizada e inconteste.

Havia ainda outro aspecto que desempenhou um papel importante em parte considerável das negociações com antigos proprietários. A Light, com a anuência do Governo estadual, passou a aceitar prestações pecuniárias para fechar acordos com proprietários e, desse modo, evitar as desapropriações. Não foi possível identificar documentos com essas tratativas e acordos, porém, a certa altura, Odette Seabra as nomeia "contribuições de melhoria”. Isso porque a ideia era que o produto das desapropriações fosse vendido e o valor arrecadado abatido do total investido pela companhia na obra. A princípio, ao menos, a estrutura jurídica do contrato celebrado entre a empresa e o governo estadual criava uma forma de remuneração do investimento pela venda em hasta pública das terras decorrentes da desapropriação, respeitados, ainda, os direitos de preferência dos antigos proprietários para adquirir os imóveis que haviam sido desapropriados. Entretanto, esse complexo sistema de apropriação e revenda tinha uma finalidade: pagar pelo investimento feito. Trata-se, portanto, de um mecanismo materialmente comparável à contribuição de melhoria.

Embora tenha havido esse aspecto de prestação pecuniária, a situação global direcionou-se em sentido diverso, pois que a Light, em verdade, tornou-se uma grande proprietária de imóveis em São Paulo sob a égide da autorização que recebera do governo paulista para promover as desapropriações necessárias ao saneamento da várzea do rio ${ }^{95}$.

O tratamento dispensado à operação imobiliária decorrente da obra foi multifacetado. Como mencionado, alguns grandes proprietários chegaram a acordos e para evitar a expropriação integral fizeram doações de frações dos imóveis localizados abaixo da faixa de expropriação. Em muitos casos, porém, uma grande quantidade de pequenos proprietários simplesmente perderam suas propriedades, notadamente nos trechos em que havia uma ocupação mais densa na forma de bairros. Nesses casos, o caminho adotado pela companhia foi a desapropriação, do que decorreram algumas contendas judiciais citadas por Seabra, mas sem indicação clara das respectivas referências processuais ${ }^{96}$.

\footnotetext{
95 Após o fim da sua concessão de 70 anos, os ativos da Light foram incorporados pela Eletrobrás e aqueles ativos que não reverteram ao poder concedente foram agregados na Brascan, depois Brookfield, sintomaticamente uma sociedade voltada a operações imobiliárias.

${ }^{96}$ SEABRA, op. cit., p. 236-8.
} 
Outro aspecto relevante é que a prática da Light de aceitar uma prestação pecuniária para evitar um processo de desapropriação gerou reações em proprietários que haviam vendido ou anuído na transferência de seus imóveis à empresa sem terem recebido essa alternativa. Nesse ponto, introduzimos um ponto importante para a caracterização jurídica do conflito, a retrocessão disciplinada no artigo 1.150 do Código Civil de 1916:

“Art. 1.150. A União, o Estado, ou o Município, oferecerá ao ex-proprietário o imóvel desapropriado, pelo preço por que o foi, o caso não tenha o destino para que se desapropriou."

Com base nessa norma, e em face da aceitação pela companhia de prestações pecuniárias: "Não paravam de chegar à Companhia inúmeros e inúmeros pedidos de retrocessão." 97

Foi com base nesse fundamento que antigos proprietários desafiaram os procedimentos da Light e levaram a disputa aos tribunais, culminando com uma decisão do Supremo Tribunal Federal. Foi igualmente por ocasião dessa controvérsia que nos foram legadas as opiniões jurídicas mais instigantes a respeito dessa desapropriação, a saber, os pareceres emitidos a pedido da Light por Vicente Ráo, José de Castro Nunes e Themístocles Brandão Cavalcanti.

Cabe pontuar que todos os juristas que ofereceram suas opiniões, cada um a seu modo, possuíam grande relevância no mundo jurídico da década de 1950. Vicente Ráo fora Ministro da Justiça e era Professor da Faculdade de Direito da Universidade de São Paulo; José de Castro Nunes era Ministro aposentado do Supremo Tribunal Federal; e Themístocles Brandão Cavalcanti fora Procurador-Geral da República e, posteriormente, nomeado Ministro do Supremo, além de ter vasta produção em direito administrativo.

A Light, portanto, não poupou esforços para defender a sua posição, tendo convocado juristas relevantes para apresentarem sua opinião a respeito do caso que se colocava perante a corte. Nisso pode ter sido relevante o papel desempenhado por Eurico Sodré, Consultor Jurídico da Light, e autor de um conhecido livro sobre desapropriações ${ }^{98}$. Independentemente do peso que tais pareceres tiveram no deslinde da questão, concretamente tem-se que o Supremo acolheu a visão esposada pelos pareceres e denegou razão aos recorrentes no Recurso Extraordinário 37.081.

\footnotetext{
${ }^{97}$ SEABRA, op. cit., p. 238.

${ }_{98}$ Trata-se de SODRÉ, Eurico. Desapropriação por necessidade ou utilidade pública. São Paulo: Saraiva, 1928. Há edições de $1945\left(2^{\mathrm{a}}\right)$ e $1955\left(3^{\mathrm{a}}\right)$.
} 
Em linhas gerais, como se viu acima, diversos imóveis foram desapropriados para permitir as intervenções e obras que se fariam na área do Rio Pinheiros. Outros imóveis que seriam beneficiados pelo fim das cheias periódicas do rio foram declarados de necessidade pública e seriam desapropriados para revenda e remuneração das obras feitas pela Light na região. De acordo com a Lei estadual 2.249/1927 e o Decreto estadual 4.487/1928, a Light haveria de se apossar dos imóveis, porém deveria os levar a hasta pública para que fossem alienados após o fim dos trabalhos. Como não haveria pagamento direto do tesouro paulista à empresa, seria essa a sua forma de remuneração, a venda dos imóveis beneficiados pelas obras, sendo a diferença entre o valor pago pela desapropriação e o valor recebido em hasta pública, isto é, a valorização imobiliária, a forma de remuneração para os investimentos feitos. Tratava-se, aparentemente, de um negócio de rentabilidade incerta se não houvesse valorização e que demandava a aplicação de muitos recursos para o pagamento de indenizações e a realização das obras.

É preciso ter em mente, ainda, que as tratativas do governo estadual e a Light previam uma forma de preferência para que os antigos proprietários pudessem readquirir os imóveis desapropriados. Foi esse, com efeito, o teor das cláusulas XX e XXI do contrato celebrado entre São Paulo e a Light e aprovado pelo Decreto 4.487/1928. Segundo esses ajustes, deveriam ser respeitados os direitos dos antigos proprietários na aquisição dos lotes a serem vendidos em hasta pública, entretanto o preço mínimo fixado computaria não apenas o valor pago a título de desapropriação, mas também os benefícios introduzidos pela Companhia na área do imóvel.

No caso específico dos recorrentes - José Theodoro de Camargo Bayeux e outros - o seu pedido foi deduzido no sentido de recuperar o preço pago a maior na recompra, ou seja, aquilo que excedera o valor que a própria companhia lhes havia pagado a título de indenização. De fato, a situação era que os recorrentes haviam recebido o valor da indenização e, ao final da obra, readquirido imóvel que antes lhes pertencia, por preço superior, no entanto. Esse preço superior decorreria, em tese, das melhorias trazidas pela Light à área, porém os autores, posteriormente recorrentes, discordavam e tencionavam repetir o indébito por meio da ação em face da Light para que esta lhes devolvesse a diferença entre o valor pago na revenda e o recebido como indenização. 
O pleito dos recorrentes se fundava no direito à retrocessão (art. $1.150 \mathrm{CC} / 1916)$, de acordo com o qual, se União, Estado ou Município não desse ao imóvel o destino pelo qual se desapropriou, poderia o antigo titular retomar o domínio por meio do pagamento daquilo que havia recebido pela desapropriação. Essa é, todavia, sem sombra de dúvida, uma disposição do Código Civil que regula e, de alguma forma, disciplina a volta da propriedade ao domínio privado de bens anteriormente a ele retirados em favor do domínio público e aos quais não tenha sido dada a destinação pretendida. É nesse sentido que Brandão Cavalcanti reputa a retrocessão uma espécie de penalidade imposta ao administrador por não dar o destino adequado àquilo que se expropriou e, correlativamente, uma defesa do particular diante de possíveis abusos do poder público:

"A boa doutrina considera a retrocessão quase que uma penalidade, uma devolução forçada, pelo não uso total ou parcial do direito de que foi investido aquele que executou a obra.",99

Posto de outra forma, a configuração de retrocessão, com a consequente volta dos bens ao domínio privado pelo pagamento de quantia idêntica à da desapropriação, pressuporia a configuração de desvio na destinação dos bens para o fim que se havia inicialmente desapropriado. Embora haja uma controvérsia, não de todo explicitada, sobre a legalidade de uma desapropriação para remuneração de uma obra pública, inconteste que o fim para o qual se desapropriou foi, sem dúvida, a revenda do acervo imobiliário após a valorização. $\mathrm{O}$ artigo $3^{\circ}$ da Lei 2.249/1927 é desde o início explícito nesse sentido:

"Artigo 3." - Ficam declarados de utilidade publica os terrenos e outros bens, indispensaveis á construcção de todas essas obras e de necessidade publica, as areas actualmente alagadiças, ou sujeitas a inundações, saneadas ou beneficiadas em consequencia dos serviços de que trata esta lei." (Grafia do original)

O governo estadual declarara de utilidade pública os imóveis necessários à obra e outros que seriam, posteriormente, utilizados para: (i) as instalações de transmissão de energia elétrica; (ii) melhoramentos em transporte e vias; (iii) construção das estações elevatórias no rio; dentre outros usos consensualmente públicos. Porém, foi feita pela legislação uma distinção entre utilidade pública e necessidade pública, tendo sido declarados de necessidade

\footnotetext{
${ }^{99}$ CAVALCANTI, Themístocles B. "Desapropriação por Zona. Retrocessão" in Revista de Direito Público, v. 7, 1969, p. 106.
} 
pública os imóveis que seriam beneficiados pelos melhoramentos e, posteriormente, vendidos para possibilitar o pagamento da obra. Em outros termos, pela sistemática das normas, haveria bens que se incorporariam de maneira definitiva ao patrimônio público e outros que o fariam de maneira transitória. No caso dos bens destinados à venda, o fundamento para a desapropriação seria o de evitar que os proprietários se beneficiassem da valorização decorrente da obra pública sem para ela concorrer financeiramente. A um primeiro olhar, poder-se-ia caracterizar como um mecanismo de certa forma gravoso destinado a evitar o fenômeno contemporaneamente caracterizado como free riding ${ }^{100}$, isto é, a apropriação privada de benefícios sem concorrer para o seu custo.

É de se prever que a obra pública teria consequências sobre o valor das propriedades ao longo do rio, sendo, por essa razão, necessário um mecanismo apto a adequar financeiramente a operação e capaz de arrecadar os fundos para remunerar a executora das obras. O governo estadual, aparentemente não disposto a utilizar o orçamento público para tal fim, achou por bem alargar o trecho a ser desapropriado, de modo que ele abrangesse todas as áreas alagáveis (isto é, os que se beneficiariam da obra), e, ato contínuo, permitir a revenda dessas áreas (impondo, pois, o custo da obra aos por ela beneficiados). A diferença decorrente da valorização pagaria o preço devido à Light, ou seja, seria uma espécie de desapropriação por zona antes mesmo da introdução desse instituto no direito brasileiro pelo artigo $4^{\circ}$ do Decreto 3.365/1941.

O parecer que resolve dogmaticamente de maneira mais aprofundada esse ponto foi o de Themístocles Brandão Cavalcanti. Ao desenvolver uma argumentação típica de prevalência do interesse público, ele expõe que a propriedade consubstanciaria um interesse privado e os melhoramentos seriam parte constitutiva do interesse público, consequentemente nada mais consentâneo que aqueles cedessem diante destes ${ }^{101}$.

No entanto, ainda que não se negue o caráter de interesse público da obra, é patente que poderia haver contestações sobre a forma e por quem as desapropriações seriam feitas. De fato, quem levou a cabo as desapropriações não foi o governo de São Paulo e, em nome da

\footnotetext{
${ }^{100}$ Para uma análise mais detida cf. OLSON, Mancur. The Logic of Collective Action: Public Goods and the Theory of Groups. Cambridge, Mass.: Harvard University Press, 1971.

${ }^{101}$ Em suas palavras: "A mentalidade privatista é incompatível com a própria noção de desapropriação para a realização de obras públicas que abranjam grandes áreas e destinadas a objetivos complexos. Há uma contradição entre essa concepção e a de interesse público que conduz necessariamente à subordinação do interesse privado ao interesse público, desde que sejam respeitados os direitos fundamentais mencionados na Constituição Federal." CAVALCANTI, op. cit., p. 110.
} 
recuperação da valorização imobiliária, foi feita uma desapropriação que transcendeu o necessário para o uso público, ou seja, os serviços públicos, os arruamentos, as faixas para transporte ferroviário.

Ademais, cabe lembrar que, embora prestadora de serviço público, a Light não gozava de poder expropriatório para além do estritamente necessário ao serviço de que era concessionária. Ela poderia sim desapropriar os particulares para manter ou ampliar o serviço, mas para remunerar uma obra pública, como o foi, dependeria da cooperação e anuência do governo estadual.

A impressão que se tem da leitura das opiniões é a de que não se questionou a proporcionalidade $^{102}$ do meio elegido para a consecução do fim público. A obra poderia certamente cumprir funções públicas relevantes, mas a desapropriação extensiva impunha pesadas restrições ao interesse privado dos antigos proprietários em nome de se evitar que eles se locupletassem do investimento público. Nessa mesma linha, a relação de sujeição, isto é, as justificativas para a expropriação foram negligenciadas em favor de uma discussão mais pautada apenas pela disciplina das relações pecuniárias ex post facto. A expropriação e sua justificativa foram bem pouco tematizadas, as relações patrimoniais pós-desapropriação receberam uma atenção mais detida e elaborada dogmaticamente do que a legitimidade da perda da propriedade em si.

Afora as colocações plubicísticas ainda tímidas de Brandão Cavalcanti, as outras discussões se cingem a questões de ordem civilística e intenso viés patrimonial. O argumento da remuneração do antigo proprietário pelas benfeitorias aduzidas pela Light ao imóvel é muitas vezes mencionado como fundamento do sobrepreço. No contexto, certamente fazia sentido porquanto os antigos proprietários não estavam a questionar propriamente a desapropriação, mas a legalidade da revenda por preço majorado. Se ilegal a revenda por preço superior ao recebido como indenização, consequentemente devida seria a repetição do indébito requerida pelos recorrentes. Em outros termos, a elaboração do pedido pelas partes caracterizou a disputa como uma contenda privada. É sintomático que assim o tenha sido, e

\footnotetext{
102 “A proporcionalidade ('Verhältnismässigkeitsgrundsatz') determina que um meio deva ser adequado, necessário - isto é, dentre todos os meios adequados aquele menos restritivo - e mantenha relação de proporcionalidade relativamente ao fim instituído pela norma." ÁVILA, Humberto. "Repensando o 'Princípio da Supremacia do Interesse Público sobre o Particular"” in SARMENTO, Daniel. Interesses Públicos versus Interesses Privados: Desconstruindo o Princípio de Supremacia do Interesse Público. Rio de Janeiro: Lumen Juris, 2007, p. 192.
} 
também o fato de o léxico do direito civil ser reiteradamente empregado, além de as opiniões jurídicas buscarem elementos de caracterização no direito privado, que à época contava com uma estrutura dogmática mais bem estabelecida que a do direito público ${ }^{103}$.

Por essa linha de raciocínio, a solução da retrocessão como penalidade para a não destinação dos bens de acordo com o decreto de utilidade pública e a indenização por benfeitorias feitas aos imóveis representava saída dogmaticamente aceitável à questão. Isso porque o decreto que declarou de utilidade e necessidade pública já previa em seu bojo quais seriam os desdobramentos da desapropriação. A norma previa igualmente o procedimento para a venda daqueles imóveis não destinados ao cumprimento de uma função pública e, ainda, o direito de preferência dos ex-proprietários e, em caso de não exercício deste, a venda em hasta pública. Ou seja, salvo se for questionada a destinação em si de uma desapropriação para revenda, não seria possível alegar que houve desvio no destino dos bens. Desde a decretação de necessidade pública (não utilidade), estavam eles destinados à alienação futura e não a serem incorporados ao patrimônio público.

Embora naquela época ainda não vigente, é possível apreender a dificuldade que havia em formular pretensões contrapostas ao Estado pelos termos que assumiu o Decreto-Lei 3.365/1941. Duas passagens são sintomáticas de sua pouca abertura a desvios do Estado:

“Art. $9^{\circ}$ Ao Poder Judiciário é vedado, no processo de desapropriação, decidir se se verificam ou não os casos de utilidade pública."

“Art. 35. Os bens expropriados, uma vez incorporados à Fazenda Pública, não podem ser objeto de reivindicação, ainda que fundada em nulidade do processo de desapropriação. Qualquer ação, julgada procedente, resolver-se-á em perdas e danos."

Esse registro histórico-jurídico de autoria do então Ministro da Justiça (1937-42) Francisco Campos ${ }^{104}$ não deixa qualquer âmbito de contraposição ao interesse privado. O seu teor é fortemente autoritário e exclui a apreciação do judiciário, deixando grande margem de discricionariedade ao administrador na emissão do decreto de utilidade pública, que não poderia ser analisado pelo juiz. Ao mesmo tempo, limita a possibilidade de o proprietário reaver a propriedade mesmo em caso de reversão judicial do processo de desapropriação. Em

\footnotetext{
103 A esse respeito cf. SEABRA FAGUNDES, Miguel. "Da contribuição do Código Civil para o direito administrativo" in Revista Forense, v. 62, 1965, pp. 5-16.

${ }^{104}$ Para um documento significativo cf. Exposição de Motivos do Decreto-Lei 3.345/1941 de autoria de Francisco Campos.
} 
uma atmosfera como essa, eleger a estratégia de arguir a inadequação da desapropriação para o atingimento de um fim público pareceria fadada ao insucesso. Seria necessário aguardar a emergência das condições de possibilidade de enunciados como "excesso de poder" e "desvio de finalidade" que introduziriam checks à atuação administrativa do Estado a despeito de disposições legais como as acima citadas.

Tendo visto que a probabilidade de se questionar a própria desapropriação foi menos central, tem-se que as questões relativas ao preço de revenda passaram ao centro dos debates jurídicos do caso. O questionamento da legalidade da venda dos imóveis a preço superior ao pago a título de indenização, uma das alegações dos autores da ação, encontra um contraponto no argumento formulado por Vicente Ráo que entendia ser a diferença entre desapropriação e revenda decorrente das benfeitorias incluídas no imóvel por fato atribuível à promotora da obra, a Light. Por essa visão, nada mais adequado que o pagamento pelo antigo proprietário pelas benfeitorias acrescidas à sua propriedade. Interessante em tal raciocínio é o pretenso movimento que busca no direito privado categorias dogmáticas para o deslinde de questões jurídicas de direito público. Essa passagem é do seguinte modo caracterizada por Ráo:

"Mas, aos poucos, esse conceito de benfeitoria, rompendo os limites do direito civil penetrou no direito público, onde passou a receber sensível amplitude e, assim ampliado, veio justificar a recuperação das despesas feitas com obras das quais resulta aumento de valor das propriedades situadas na zona dessarte beneficiada, segundo revelam as leis nossas e alienígenas citadas e os autores cujo parecer acima ficou transcrito."105

Ou seja, à falta de estipulações expressas sobre a disciplina específica da relação de direito público que se estabelece entre expropriante (ainda que delegatário do poder público como a Light) e expropriado, buscou o jurista critérios normativos da relação entre particulares, o regime de retribuição por benfeitorias, para solucionar um caso em que a benfeitoria fora feita de modo generalizado, por se tratar de obra pública. Cabe notar que, futuramente, seria esse ponto resolvido por mecanismos tributários, a contribuição de melhoria e as regras a ela atinentes, que possuem um caráter geral, além de regras específicas de viés publicístico.

A rigor, no entanto, as regras do direito privado regeriam somente a saída da propriedade do domínio privado em favor do Estado, esse o limite de sua atribuição. Sobre

\footnotetext{
${ }^{105}$ RÁO, Vicente. "Desapropriação por Zona. Retrocessão" in Revista de Direito Público, v. 7, 1969, pp. 88-9.
} 
esse tema, citando uma passagem de Clóvis Beviláqua, Vicente Ráo expõe a razão e o âmbito de aplicabilidade das tais regras sobre desapropriação no Código Civil:

"O art. 590 do Código Civil figurava neste corpo de leis segundo Clóvis (comentário ao texto) 'simplesmente como um dos modos pelos quais se extingue a propriedade. Ficaria incompleta a teoria da propriedade no direito civil se não mencionasse a desapropriação por necessidade ou utilidade pública."106

Portanto, buscar no direito privado a resposta não provê respostas à questão anterior e fundamental que seria a dos motivos e justificativas que determinam a saída de bens do domínio privado, sendo este o tema por excelência da sujeição do interesse particular ao público. A contraposição entre o público e o privado que de tal forma pautou a elaboração dogmática no próximo caso que se analisará (Metrô de Santana) restou, entretanto, esmorecida, esvaziada na desapropriação do Rio Pinheiros.

Ao mesmo tempo, pouco refletiram os registros jurídicos aquilo que Odette Seabra nomeou "o mais trágico exemplo, (...) o da enchente de 1929."107 Da leitura dos documentos judiciários, apenas extrai-se um cotidiano distante e a construção de uma realidade pouco permeável à representação de uma totalidade do conflito. A distância que separa os relatos jornalísticos contemporâneos à enchente e as leituras jurídicas dos fatos é significativa. Possivelmente isso se deve ao fato de desempenharem papéis muito distintos os relatos jurídicos e aqueles jornalísticos; pelo fato talvez de a forma jornalística responder imediatamente à volubilidade dos acontecimentos, sem que necessariamente consiga expor de forma séria e problemática o acontecido; e o direito, por sua vez, filtrar o conflito por suas categorias, abstrair o conflito premente e, por essa via, preparar a decisão num contexto já abstraído e sem a pungência do conflito real.

Ainda assim, tudo indica uma inabilidade do reflexo do real no jurídico, indica uma lente que não capta muitas das frações do ocorrido. A referência que aqui nos interessa é a separação entre o público e o privado, as suas formas de definição. Claramente, esses dois âmbitos não estão suspensos no evolver histórico, em verdade, a própria constituição desses pontos de discurso está fundada em situações e contextos históricos específicos. O que se depreende da análise mais detida do caso do Rio Pinheiros era que a centralidade dessa

\footnotetext{
${ }^{106}$ RÁO, op. cit., p. 83.

${ }^{107}$ SEABRA, op. cit., p. 262.
} 
dualidade ainda era incipiente, não constituíam campos bem delimitados. $\mathrm{O}$ fato de uma empresa privada ter assumido - sem grandes questionamentos - atividades e funções, posteriormente, consideradas eminentemente públicas muito diz sobre as alterações que ainda ocorreriam nas concepções e configurações dessa dualidade. Com pouca razão poder-se-ia reputar estáticos os campos do público e do privado.

Pelo contraste há de se evidenciar essas mudanças que separam o Rio Pinheiros do próximo momento, o Metrô de Santana, em que os Ministro do Supremo se mostram mais ciosos em delimitar o que pertence ao público, e os meios para seu pertencimento, e aquilo que deve ser deixado e tutelado como privado. 


\section{A Desapropriação do Metrô de Santana}

Ao longo de quase um ano, o Supremo Tribunal Federal discutiu a constitucionalidade de uma desapropriação por zona levada a efeito no Município de São Paulo pela Empresa Municipal de Urbanização - EMURB. Transcorreu mais de um ano entre a apresentação do relatório e voto do Ministro Rodrigues Alckmin, em 16 de março de 1977, e a emissão da opinião do recém-empossado Ministro Soares Muñoz em 14 de abril de 1978. Nesse meio tempo, os Ministros expuseram no Plenário do Supremo a sua opinião acerca dos pontos debatidos no Recurso Extraordinário $82.300^{108}$, que culminou em uma decisão tomada por maioria apertada de seis votos a cinco.

Segundo os relatos fáticos apresentados nos autos, o intuito do poder público municipal seria a criação de um bairro modelo em Santana, com baixos índices de ocupação e grande quantidade de áreas verdes. Essa intervenção urbanística seria feita por ocasião da extensão da linha do metrô paulistano e sua chegada ao bairro. De acordo com a visão da EMURB e dos urbanistas, seria preciso modificar alguns dos caracteres urbanos do bairro para adensá-lo e maximizar a utilidade que seria extraída dos investimentos em transporte público. Das informações prestadas pela autoridade coatora, o Ministro Cunha Peixoto retém o seguinte trecho acerca dos objetivos da intervenção:

“Cuida-se, portanto, [o projeto urbanístico] de substituir um bairro, em iminência de sofrer o início de incontrolável processo desenvolvimentista [em função da introdução do metrô] e que pode conduzi-lo a deterioração prematura, por bairro cujos moradores desfrutem de condições sem paralelo, em toda a cidade."109

Em termos concretos e sendo o que nos cabe, por ora, fixar é que a intenção manifestada pelos urbanistas por trás do projeto seria a de modificar certos aspectos estruturais do bairro a fim de torná-lo mais adequado à densidade populacional necessária ao melhor aproveitamento do metrô. Para executar tais melhoramentos, os urbanistas tinham antes de passar pela estruturação jurídica do plano, o que envolveria, necessariamente, a desapropriação das áreas necessárias à intervenção na área. Nesse ponto, encontram-se os anseios dos urbanistas com os meios juridicamente necessários.

\footnotetext{
${ }^{108}$ A íntegra do acórdão foi publicada na Revista Trimestral de Jurisprudência, v. 86, pp. 155 e ss. Os principais excertos foram publicados como apêndice ao livro DALLARI, Adilson Abreu. Desapropriação para Fins Urbanísticos. Rio de Janeiro: Editora Forense, 1981, pp. 129 e ss.

${ }^{109}$ Voto do Ministro Cunha Peixoto no RE 82.300. Citado em DALLARI, op. Cit., p. 140.
} 
Do ponto de vista estritamente jurídico processual, tratava-se de um mandado de segurança preventivo impetrado por Nelson Teixeira de Barros Moraes contra o Prefeito Municipal de São Paulo e o Presidente da EMURB. O Sr. Nelson Teixeira manejou o instrumento a fim de barrar eventual decreto de utilidade pública a ser emitido para a desapropriação de seu imóvel, que se encontrava na circunscrição dos projetos de renovação urbana da área do metrô de Santana. Posto brevemente, o impetrante questionava o fundamento jurídico da desapropriação de seu imóvel. Indiretamente, questionava a licitude de uma desapropriação que tencionava, após a renovação, possibilitar a revenda de imóveis desapropriados pela municipalidade para financiar a obra pública e evitar que os proprietários de imóveis da região apropriassem a valorização extraordinária decorrente de investimentos públicos, como haveria de ser o caso do metrô.

Nesse ponto, surge uma das divergências mais relevantes entre impetrante e autoridade coatora. A Prefeitura defendia o mecanismo de desapropriação basicamente pelos seguintes motivos:

1. Permitiria a adaptação urbanística da área, inviável sem a readequação territorial;

2. Evitaria que os atuais proprietários capturassem a valorização imobiliária decorrente de investimento público; e

3. Criaria um "esquema econômico-financeiro ${ }^{110 "}$ para financiamento das obras, de modo que seu custo não onerasse o orçamento municipal.

De outro lado, um dos argumentos centrais do impetrante afirmava que, com o advento da contribuição de melhoria, não mais se poderia aceitar a utilização da desapropriação por zona para fins de revenda e captura da valorização imobiliária decorrente de obra pública ${ }^{111}$. Em outras palavras, a contribuição de melhoria seria um instrumento menos gravoso, por não envolver a expropriação, e deveria, consequentemente, ser utilizado em lugar da

\footnotetext{
${ }^{110}$ Nas informações prestadas pela EMURB e Prefeitura nos autos, há menção expressa ao "esquema econômicofinanceiro" representado pelo projeto de desapropriação, urbanização e revenda. Cf. Voto do Ministro Moreira Alves no RE 82.300. Citado em DALLARI, op. Cit., p. 150.

111 Nessa passagem o apelante encontra-se bem acompanhado pela doutrina: "O enunciado da cláusula constitucional [sobre desapropriações] não se relaciona com o custeio de obras ou serviços, que para tal os fundos hão de provir de tributação. Nem se relaciona, também, com o combate à especulação imobiliária, que a este propósito atende o poder de polícia, inclusive através da jurisdição impositiva manipulada no interesse de reprimir abusos com o gravame das atividades ou operações abusivas." SEABRA FAGUNDES, Miguel. "Desapropriação para Urbanização e Reurbanização. Validade da Revenda", Revista de Direito Administrativo, v.128, 1977, p. 27.
} 
desapropriação por zona, em si um meio mais gravoso ao particular do que a exação de um tributo $^{112}$.

Uma passagem relevante da argumentação do autor levanta a questão dos limites impostos ao exercício do direito de propriedade e a sua devida interpretação diante da Constituição de 1946 e suas emendas. Fez referência o autor do recurso igualmente ao momento em que fora editado o Decreto-Lei 3.365/1941, ainda sob a égide da Constituição de 1937, bem menos liberal no que se referia a garantias individuais. Por essa razão, prossegue o autor em sua arguição incidental de inconstitucionalidade do art. $4^{\circ}$ do Decreto-Lei, justamente o fundamento legal da desapropriação por zona, em função de ser esse um mecanismo jurídico que, segundo ele, não se coadunaria com o sistema constitucional vigente.

Não obstante os argumentos do autor, a primeira impressão que seu recurso recebeu no STF foi contrária. Ao não conhecer do recurso do autor, o Ministro relator Rodrigues Alckmin se posiciona no sentido de que a desapropriação atinge o bem do particular, sem dúvida, mas por um mero reflexo de um fim público relevante, a reurbanização da área necessária à implantação do metrô. Dessa forma, portanto, a ação da Prefeitura e da EMURB cumpriria um fim lícito e previsto na legislação, o que elidiria possíveis fundamentos jurídicos para se reputar ilegais os atos do poder público municipal. Indiretamente, estava implícito em sua linha de pensamento que o ato do Estado que se imiscui na propriedade privada deveria passar por um teste básico, implícito na legislação, o do uso público ${ }^{113}$ ou de interesse público.

Embora não seja este o momento para aprofundamento nesse sentido, é importante uma breve digressão para dizer que um dos pontos centrais da interpretação e jurisprudência em Takings nos Estados Unidos é justamente o de se saber se o fim da expropriação criará realmente um uso público da propriedade privada, em cumprimento ao trecho da Quinta Emenda à Constituição Americana:

\footnotetext{
112 Richard Epstein, ao analisar a Special Assessment Tax, instrumento comparável à contribuição de melhoria, posiciona-se no sentido de que não haveria fundamental diferença entre os mecanismos expropriatórios e tributários: "In sum, the whole history of special assessments shows the futility of maintaining a rigid categorical distinction between taxing and takings." EPSTEIN, Richard A. Takings: Private property and the power of eminente domain. Cambridge, Mass.: Harvard University Press, 1985, p. 289.

${ }^{113}$ Os tribunais dos Estados Unidos enfrentam frequentemente essa questão em virtude da literalidade do uso público como requisito a justificar a desapropriação. "At a minimum the public use requirement is a strict limitation upon the power of government to take private proprerty." EPSTEIN, op. cit., p. 162. Em sentido oposto: "First, we shall not construe the textual command that takings be made for 'public use'. While the modern understanding of 'public use' that any state purpose otherwise constitutional should qualify as sufficiently 'public' to justify a taking (...)” ACKERMAN, Bruce A. Private Property and the Constitution. New Haven: Yale University Press, 1977.
} 
“(...) nor shall private property be taken for public use, without just compensation”.

O critério do uso público, e a revisão judicial desse critério, parece menos provável em um ordenamento constitucional que conferiu ênfase mais intensa à indenização, sua forma e tempo, como o brasileiro. Dogmaticamente, ainda que não explícito, o fundamento do uso público foi introduzido por meio de um mecanismo caro ao direito administrativo francês, o desvio de finalidade, ou originalmente excès de pouvoir ${ }^{114}$. Na forma desse teste, o mero decreto de utilidade pública não consubstanciaria, por si, um fim público relevante, pois pode ter sido emitido de forma irregular e ser uma manifestação não do Estado como portador do interesse público, mas mero desvio do administrador que o representa.

É interessante notar como a construção dogmática do direito administrativo francês destoa sensivelmente nos dois grupos de países, França/Brasil e Estados Unidos. Ainda que não se possa fazer uma afirmação clara sobre a França, é possível uma ilação sobre o Brasil, a partir de um trecho de José Murilo de Carvalho sobre a formação do Estado Imperial:

"No Brasil [em comparação ao Estado português baseado em uma aliança entre a burocracia e grandes comerciantes], a terra voltou a ser a principal fonte de riqueza e poder e, consequentemente, os proprietários, às vezes nobres portugueses empobrecidos, recuperaram o antigo prestígio. A centralização conseguida pelo Estado português viu-se aqui reduzida a modestas proporções frente aos grandes latifúndios e à dispersão da população por um território tão extenso. A construção do Estado no Brasil não poderia ser feita sem levar em consideração esses novos e importantes fatores."

Adiante, ao comentar a forma distinta de ver o Estado, ele contrasta Brasil e Estados Unidos:

"A situação distinguia-se muito da americana, na qual o emprego público era em geral um mau negócio, além de ser malvisto pela população."116

Trazendo essas contribuições para o caso concreto, tem-se que num contexto em que a formação das elites, e sua dependência do Estado, se contrapõe a outro em que as elites viam

\footnotetext{
${ }^{114}$ Cf. Voto do Ministro Cunha Peixoto no RE 82.300. Citado em DALLARI, op. Cit., p. 139. Como fonte remota o julgado do Conseil d'Etat, Assemblé, 17.02.1950, $\mathrm{n}^{\circ}$ 86.949, Ministre de l'Agriculture contre Dame Lamotte: “(...) elle [a lei] n'a pas exclu le recours pour excès de pouvoir devant le Conseil d'Etat contre l'acte de concession, recours qui est ouvert même sans texte contre tout acte administratif, et qui a pour effet d'assurer, conformément aux principes généraux du droit, le respect de la légalité."

${ }^{115}$ CARVALHO, José Murilo. A Construção da Ordem: A elite política imperial/Teatro das Sombras: A política imperial. Rio de Janeiro: Civilização Brasileira, 2003, p. 38.

${ }^{116}$ Id., p. 41.
} 
de forma negativa o próprio Estado, seria esta, portanto, mais tendente a criar mecanismos de contenção. A amplitude que se deu ao critério de uso público (public use) em comparação ao tratamento mais laço, ainda que não ilimitado, ao poder de expropriar no Brasil, pode denotar uma concepção mais afeita a aceitar a expropriação, pois Estado e elites políticas e burocráticas possuíam interesses convergentes que não demandavam a criação de testes (e checks) ao poder político, imbricado que estava com a elite territorial. Por esta linha de pensamento, a interação com o Estado faria com que a necessidade de se criar um critério normativo-protetivo abstrato e de maior amplitude seja substituído por uma proteção derivada do próprio controle e familiaridade com o poder de expropriar. Em tal contexto, consequentemente, esse poder teria limitações menos claras, contornos menos marcados e pouca limitação explícita e normativamente abstrata.

A constituição de 1937, que levou o pêndulo da relação Estado/indivíduo excessivamente para o lado estatal, possuía, com efeito, um âmbito de proteção pouco amplo no que tange às limitações ao poder expropriatório. Isso, em verdade, bem havia notado o recorrente no RE 82.300. Veja-se o texto constitucional a respeito:

“Art. 122 - A Constituição assegura aos brasileiros e estrangeiros residentes no País o direito à liberdade, à segurança individual e à propriedade, nos termos seguintes:

(omissis)

14) o direito de propriedade, salvo a desapropriação por necessidade ou utilidade pública, mediante indenização prévia. O seu conteúdo e os seus limites serão os definidos nas leis que lhe regularem o exercício;"

A afirmação do direito de propriedade já vem ressalvada pela desapropriação no mesmo enunciado de forma a aclarar que, embora existente, a desapropriação já constitui um dos termos de acordo com os quais o direito de propriedade será exercido. O contraponto do privado à expropriação seria apenas a "indenização prévia”, em tese, não podendo o particular contrapor ao Estado um critério material, como seria o do uso público, a fim de contrapor-se à perda da propriedade. No mais, uma ambiguidade na segunda frase do texto normativo poderia dar ensejo a uma interpretação de que ou o direito de propriedade, ou a desapropriação, seriam regulados pela legislação ordinária. Tomando-se a primeira hipótese, haveria uma situação sensivelmente complexa na qual o conteúdo da propriedade, e suas limitações, seriam objeto de disciplina legal. Embora seja em princípio esse o papel do Livro de Direito das Coisas do 
Código Civil, a menção à disponibilidade, por via legal, do conteúdo do direito de propriedade, no contexto da Constituição de 1937, trazia fortes impressões de que, frente ao Estado, dificilmente haveria formas de contraposição válida do particular.

Embora fortemente mais protetiva, a Constituição de 1988 não aprofundou, em sua literalidade, as garantias de manutenção da propriedade, porém reforçou os critérios no artigo $5^{\circ}$ e introduziu de forma mais contundente, em outros artigos, o critério social de exercício do direito de propriedade. Ao que a leitura comparada indica, não houve a introdução de um critério material, ainda que com conteúdo a determinar, para controlar as desapropriações.

Eis o trecho sobre o tema e seus requisitos procedimentais:

"XXIV - a lei estabelecerá o procedimento para desapropriação por necessidade ou utilidade pública, ou por interesse social, mediante justa e prévia indenização em dinheiro, ressalvados os casos previstos nesta Constituição"

Embora não seja propriamente o objetivo, parecem ser relevantes alguns comentários sobre os caracteres constitucionais atuais da desapropriação. $\mathrm{O}$ argumento material, a principal defesa, de um proprietário nos Estados Unidos para resistir ao ímpeto expropriante do Estado seria desconstruir - ou mostrar ser injustificável - a ação para o uso público. Em comparação, o constitucionalismo no Brasil tendeu a adotar uma série de critérios procedimentais, ao que tudo indica, acrescidos paulatinamente diante da prática de abusos dos administradores. Dessa forma, o que fora inicialmente indenização prévia transformou-se em indenização justa, prévia e em dinheiro.

Voltando um passo no argumento, cabe pontuar que a disciplina da propriedade e da desapropriação na Constituição de 1824 seguia de forma mais próxima a fórmula adotada pela

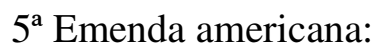

“Art. 179. A inviolabilidade dos Direitos Civis, e Politicos dos Cidadãos Brazileiros, que tem por base a liberdade, a segurança individual, e a propriedade, é garantida pela Constituição do Imperio, pela maneira seguinte:

(omissis)

XXII. É garantido o Direito de Propriedade em toda a sua plenitude. Se o bem publico legalmente verificado exigir o uso, e emprego da Propriedade do Cidadão, será elle préviamente indemnisado do valor della. A Lei marcará os casos, em que terá logar esta unica excepção, e dará as regras para se determinar a indemnização (Grafia original)." 
A Constituição de 1890, por sua vez, passa a adotar uma forma mais em acordo com o enunciado atual, inaugurando uma forma de organização perene sobre o assunto:

“Art 72 - A Constituição assegura a brasileiros e a estrangeiros residentes no País a inviolabilidade dos direitos concernentes à liberdade, à segurança individual e à propriedade, nos termos seguintes:

(omissis)

$\S 17$ - O direito de propriedade mantém-se em toda a sua plenitude, salvo a desapropriação por necessidade ou utilidade pública, mediante indenização prévia."

O uso público e o bem público são, de algum modo, pressupostos na própria forma de desapropriação, por bem ou utilidade pública, porém como expusemos o problema central do uso público, melhor do uso público justificável, resta implícito.

Após essa digressão com uma pequena história dos enunciados sobre desapropriação nas Constituições brasileiras, avancemos ao ponto em que o Ministro Rodrigues Alckmin arremata a sua argumentação para rejeitar o recurso do proprietário:

"Não vejo, assim, na desapropriação para execução do plano de renovação da área (sic), tendo à vista a utilidade pública de torná-la adequada às novas condições reclamadas para o local; e tendo à vista que as edificações ainda que não decadentes, 'se tornarão obsoletas logo que o metrô começar a funcionar', ofensa ao invocado princípio da Constituição, assegurador do direito de propriedade, ressalvada, porém, a desapropriação."117

O que se extrai da argumentação do Ministro, consequentemente, é que se houvesse um fim público no ato expropriatório, ainda que não um fim público imediato, seria aceitável e subsistira o ato frente ao crivo do controle judicial. Essa posição fica, com efeito, em linha com as concepções mais procedimentais do que substantivas dos textos constitucionais. $\mathrm{O}$ resultado líquido desse arranjo seria, logicamente, um alargamento do âmbito de discricionariedade administrativa que, pois seus desdobramentos - por exemplo, quando fosse objeto de apreciação jurisdicional - não se poderia, com clareza, definir o que, ao fim, constitui ou não caso de utilidade pública.

Nessa visão esposada pelo Ministro, tendo sido emitido o decreto e declarado por esse meio o que o administrador entendia convergir com o interesse público, restaria ao judiciário

\footnotetext{
${ }^{117}$ Voto do Ministro Rodrigues de Alckmin no RE 82.300. Citado em DALLARI, op. Cit., p. 135.
} 
somente limitar, no caso concreto, abusos que nem mesmo mediatamente pareceriam convergir com o interesse público. Dado que o critério do uso público não existia nos textos constitucionais da República, uma das formas - sendo impossível afirmar peremptoriamente ter sido a única - foi o recurso do expropriado à caracterização do desvio de finalidade. Por essa via, o judiciário não se imiscuía diretamente na discricionariedade e apreciação do administrador sobre o que constituiria o interesse público. Afinal, se havia sido emitido o decreto de utilidade pública, o administrador, em sua apreciação, já se posicionara. Contudo, caberia ao Judiciário reputar ilegal o ato pela não convergência com o interesse público, ainda que, formalmente, tenha havido uma manifestação de órgão do Estado sobre o que entende ser a utilidade pública.

Certamente, a questão que se coloca é qual seria a fonte dessa incompatibilidade (interesse público formal vs. material) frente à aferição judicial e mesmo porque a consonância com um pretenso interesse público material de fundamentos jurisprudenciais não constituiria critério normativo explícito. O art. $2^{\circ}$ do Decreto-Lei 3.365/1941 é, na verdade, sintético ao estatuir:

"Art. $2^{\circ}$ Mediante declaração de utilidade pública, todos os bens poderão ser desapropriados pela União, pelos Estados, Municípios, Distrito Federal e Territórios."

Ao que a norma indica, bastaria a emissão do decreto pelo representante de um dos chefes do poder executivo dos entes federativos descritos no artigo para que qualquer bem, sem restrições aparentes, ao menos no que tange aos particulares, pudesse ser desapropriado. Discussões quanto a procedimento e quantias devidas não são excluídas, no entanto, pelo conteúdo da norma, mas torna-se complexa a desconstituição de uma utilidade pública declarada por um decreto. No limite, aquele que desejasse opor-se à desapropriação deveria arguir a incompatibilidade do decreto a uma utilidade pública material, que não existiria e que teria sido mal avaliada pelo administrador. A estratégia, no mais das vezes, - dado que inexistente o critério legal explícito do uso público - iria no sentido de se reputar inconsistente com o próprio bem comum, utilidade pública ou outro locus argumentativo semelhante. Em ambos os casos, no entanto, inobstante a circunstância de o critério ser explícito ou extraído de uma análise ampla do espectro normativo, há um conceito aberto cuja concretização depende de uma ponderação concreta para preencher o sentido normativo que terá o conceito de utilidade pública. 
Desse modo, ainda que não de forma ilimitada, ao analisar uma questão de desvio de finalidade pública na emissão de um decreto de utilidade pública, o juiz encontra-se diante de uma situação em que o recurso a regras pouco o ajuda ou aponta em direção unívoca. Consequentemente, a probabilidade de haver decisões divergentes aumenta consideravelmente. Pode ser essa razão, com efeito, uma das explicações sobre a grande divisão do STF ao analisar o caso do Metrô de Santana, no qual dos onze votos cinco foram em uma direção e seis em outra.

De uma perspectiva mais teórica, há uma passagem de Dworkin sobre o papel que desempenha a discricionariedade num contexto em que princípios não impõe deveres tão claros como o das regras, e que, por essa razão, faz surgir discordâncias quanto ao conteúdo das decisões e sua pertinência com o direito:

"This is the argument that when judges disagree about matters of principle they disagree not about what the law requires but about how their discretion should be exercised. They disagree, that is, not about where their duty to decide lies, but about how they ought to decide, all things considered, given that they have no duty to decide either way."118

O caso do desvio de finalidade na emissão de decretos de utilidade pública possui as características próprias a situações como essas em que as divergências na interpretação para se chegar a uma decisão é mais acentuada. Isso por que, quando há critérios mais claros e a aferição depende menos de uma interpretação de princípios abertos como os de moralidade administrativa, por exemplo, há maior probabilidade de convergência nas opiniões. Diante de critérios menos concretos e mais latos, a moldura para a tomada de decisão, de acordo com a norma, alarga-se.

Dito isso, passemos aos próximos votos para observar mais de perto a forma como o judiciário interpretou e lidou com a concretização de padrões normativos abertos. O próximo Ministro a se manifestar nos autos foi Cunha Peixoto, de forma ligeiramente mais extensa que a do relator Rodrigues Alckmin. O Ministro define seu argumento a partir de uma pergunta que norteará a exposição: “Cuida-se, pois, de saber se é lícito ao Poder Público desapropriar imóvel urbano para fins de revenda". Isso porque parte substancial das discussões em torno da legalidade e constitucionalidade da desapropriação por zona havia sido, constantemente, a

\footnotetext{
${ }^{118}$ DWORKIN, Ronald. Taking Rights Seriously. Cambridge, Mass.: Harvard University Press, 1978, pp. 68-9.
} 
discrepância entre uma utilidade pública que não envolva, necessariamente, a criação de uma propriedade pública.

Nos casos de desapropriação para revenda torna-se mais clara essa incompatibilidade e menos clara, para alguns, a efetiva utilidade pública. Isso porque, ao revender os imóveis oriundos da desapropriação, o que ocorre é uma passagem fugaz pelo domínio público para posterior retorno ao domínio privado. Em tal contexto, a justificativa da utilidade pública requer elementos que vão além da tradicional transformação em público de um bem antes privado com o fim de lhe dar uma função pública, que só poderia ser atingida por meio da titularidade pública do bem. A equivalência e equiparação de utilidade pública a propriedade pública, em sua concretude, torna mais fáceis os critérios de aferição da legalidade e razoabilidade de uma desapropriação. As questões surgirão, todavia, quando a utilidade pública não exigir, impreterivelmente, a incorporação do bem ao domínio público. Ou seja, não exigir que se opere uma identidade entre bens públicos e a utilidade pública que se lhe extrai. Para isso será necessário um critério mais abstrato de utilidade pública que não se restringiria somente ao titular do bem, mas se pautaria pela função que o bem desempenha, independentemente da sua titularidade.

Sem dúvida, a Prefeitura de São Paulo estava ciente desse aspecto e, por isso, buscou fundamentar a sua posição não na compatibilidade entre propriedade pública e função/utilidade pública, mas sim a utilidade pública em sentido finalístico, a instrumentalização dos bens públicos, ainda que transitórios, como necessários à execução de uma obra pública relevante de preparação para as mudanças na mobilidade urbana da área. Por essa linha de pensamento, a utilidade pública seria atingida por meio da desapropriação, mas tal utilidade não permaneceria dependente da titularidade do bem, que poderia ser entregue aos particulares. Com efeito, especialmente no caso de reurbanização, se o bem permanecesse como titularidade do Município mais provável seria que a utilidade pública, ao invés de alcançada, fosse sim impossibilitada em razão de não se poder repovoar o bairro na linha do pretendido pelo plano urbanístico e de mobilidade urbana.

Por essa visão, de forma muito perspicaz, é feita uma distinção entre função e propriedade pública. Distinção também importante, por exemplo, para fundamentar a legalidade de os concessionários de serviço público - que desempenham uma função pública receberem os bens decorrentes de uma desapropriação. Esses bens, ainda que tornados 
privados pelo viés patrimonial, não deixam de estar afetados a uma função pública relevante, sofrendo mesmo limitações à sua disposição. É esse, por exemplo, o caso da reversão dos bens ao fim da prestação de serviços públicos. O trecho seguinte da Lei de Concessões (Lei 8.987/1995) é claro ao estipular que ao concessionário não caberá a titularidade do bem afeto ao serviço, mas sim a indenização daquilo que não houver sido amortizado ao longo da concessão. Indiretamente, trata-se de uma desapropriação, do ponto de vista da titularidade, mas do ponto de vista da função o bem estava afetado desde o início, ainda que sob titularidade privada:

"Art. 36. A reversão no advento do termo contratual far-se-á com a indenização das parcelas dos investimentos vinculados a bens reversíveis, ainda não amortizados ou depreciados, que tenham sido realizados com o objetivo de garantir a continuidade $e$ atualidade do serviço concedido."

O Ministro Cunha Peixoto, entretanto, elegeu uma visão restritiva dos limites da desapropriação de modo que o direito de propriedade apenas poderia ser restringido no que fosse estritamente necessário a uma utilidade pública consubstanciada, por sua vez, necessariamente em propriedade pública. Todo o mais seria especulação imobiliária, atividade mercantil cujo desempenho não seria lícito em conjunto com o uso do domínio eminente do Estado. Em suas palavras:

"O Tribunal [ao comentar uma decisão da Suprema Corte Argentina] não achou justo desapropriar para fazer renda (...)

O estatuto básico [no direito brasileiro] é claro: tira-se a propriedade só em caso EXCEPCIONAL, para atender à necessidade ou utilidade pública; portanto, unicamente na medida do indispensável para o fim social colimado."119

$\mathrm{O}$ voto do Ministro posicionou-se, portanto, de forma contrária à desapropriação. Em seu voto o Ministro considerou que ao subtrair a propriedade aos particulares para uma intervenção urbanística com o fito de depois revendê-la, nesse caso o Estado estaria a ultrapassar os limites admissíveis do regime de exceção imposto às desapropriações. A exceção seria o uso público cumulada com a titularidade pública do bem, a desapropriação para revenda, pois, seria uma atividade imobiliária mais do que a concretização de uma finalidade pública relevante.

\footnotetext{
${ }^{119}$ Voto do Ministro Cunha Peixoto no Recurso Extraordinário 82.300.
} 
$\mathrm{O}$ voto de Cunha Peixoto, entretanto, pode-se dizer, apenas preparou o terreno para uma crítica ainda mais contundente, a que foi feita na sessão de 01 de dezembro de 1977 pelo então Ministro Moreira Alves, tendo essa manifestação sido precedida de pedido de vista. A análise do Ministro repassou os argumentos trazidos pela autoridade coatora, além de ter empreendido uma análise detida de duas Leis Municipais: 7.670/1971 e 7.859/1973 relevantes para o caso. A primeira havia criado a EMURB e lhe estabelecera os objetivos e meios de atuação:

"Art. $5^{\circ}$ A EMURB terá por objetivo a execução de programas de obras de desenvolvimento de áreas urbanas, bem como de planos de renovação das que se apresentarem em processo de deterioração, elaborados uns e outros, pelos órgãos próprios da Prefeitura, e aprovados prèviamente (sic) pela Câmara Municipal.

$\S$ único - Para a consecução de seus fins, a EMURB poderá desenvolver tôda (sic) $e$ qualquer atividade econômica a tal efeito necessária, inclusive adquirir e alienar, por compra e venda, bem como promover a desapropriação de imóveis, obedecida a legislação pertinente, em função da estrita execuções dos programas e planos de melhoramentos específicos aprovados pelo Legislativo Municipal (omissis)."

A Lei 7.859/1973, por sua vez, havia fixado os limites do perímetro para a intervenção urbanística nos bairros que receberiam as novas estações do metrô: Santana e Jabaquara. Em Santana o perímetro para a execução de renovação urbana contaria com $147.000 \mathrm{~m}^{2}$ e, dentro dessa área, seriam promovidas as desapropriações nos termos da Lei que criou a EMURB e da legislação pertinente.

O Ministro Moreira Alves inicia seu voto pontuando alguns dos aspectos legislativos e procedimentais do caso apresentado ao Supremo. Ressalta que a empresa pública foi criada com o intuito de executar planos de urbanização e que houve a edição de lei específica para delimitar o âmbito em que ocorreria a intervenção urbanística no bairro de Santana. Ao citar os argumentos de memorial apresentado pela EMURB e pela Prefeitura, tece comentários aos aspectos relevantes da obra pública, notadamente o fato de se tratar de uma intervenção necessária à readequação do bairro e para a criação de novas condições urbanas propícias à introdução do novo meio de transporte de massa. 
O Ministro não nega esse aspecto, reconhece-o como relevante, mas segue para uma distinção feita a partir de um diálogo com Eurico Sodré (A Desapropriação ${ }^{120}$ ). Pela distinção feita pelo Ministro, seria importante estabelecer que a revenda de área produto de desapropriação seria, em tese, lícita. Dignos de menção seriam os casos, por exemplo, em que há sobra de área ao fim de obra pública, as chamadas áreas remanescentes de desapropriação. Essas não mais são necessárias ao término da obra pública, mas foram imprescindíveis à consecução desta. Em parte, essas situações seriam melhor solucionadas pelo regime de ocupação temporária, com indenização, que substituiria as complicações inerentes à entrada e posterior saída de bens remanescentes do patrimônio imobiliário do Estado, o que demanda procedimentos licitatórios.

No entanto, relevante nesse momento é identificar a característica de que a desapropriação ou ocupação temporária possuem um caráter instrumental à consecução de uma finalidade pública. Ou seja, a propriedade pública, ou o uso público da propriedade privada com indenização, são ambos meios para que a utilidade pública seja atingida. Nesse sentido, portanto, a princípio, não haveria propriamente violação às limitações impostas ao Estado quando este intervém no domínio privado, porquanto estas intervenções seriam justificadas com base na exceção segundo a qual seria lícita a expropriação para uso público desde que dirigida à consecução de um fim público.

Por esse fundamento, o Ministro Moreira Alves reputa lícitas as desapropriações que de tal forma transformam um bem imobiliário a ponto de criar a sua utilidade por meio da execução de uma obra pública. Por meio do mesmo Eurico Sodré, é mencionado o caso da desapropriação do Rio Pinheiros (RE 37.081, analisado acima), no qual teria sido lícita a revenda dos imóveis, primeiramente, por serem eles imprescindíveis à concretização da obra de saneamento da várzea (o que só seria correto afirmar nos casos de utilidade pública). E em segundo, porque a permanência daqueles imóveis no patrimônio público estaria em desacordo com o interesse público e a função instrumental que o domínio público deveria ter nesse caso. A lógica nessa passagem é semelhante à da alienação de áreas remanescentes em desapropriações: essas áreas são necessárias ao interesse público, ainda que temporariamente, por isso devem ser desapropriadas; quando deixarem de ser poderão ser alienadas em função

\footnotetext{
${ }^{120}$ SODRÉ, Eurico. A Desapropriação. São Paulo: Saraiva, 2a Ed., 1945.
} 
de o próprio interesse público exigir que não mais o Estado retenha os bens dominicais, mas que entregue aos particulares para que estes lhes deem destinação adequada.

Essa digressão para a criação de uma distinção, no caso de Moreira Alves, faz a preparação de uma crítica ao que tinha por objetivo fazer a Prefeitura São Paulo. Isso porque, segundo o Ministro, haveria um limite muito claro, quase moral, para qualquer das operações imobiliárias do poder público e o Município o havia ultrapassado, de acordo com essa visão:

"O que não se consente é a desapropriação com o fito exclusivo de especulação."121

Para o Ministro, a desapropriação nos arredores de Santana não era um caso de área necessária para a execução de obras e tampouco o caso de uma obra que geraria áreas remanescentes para posterior revenda. Ao expor dados dos planos de urbanização e a quantidade de metros quadrados de habitação e comércio que pretendiam ser criados na área, o Ministro expõe que a intervenção urbanística teria por fim, em verdade, criar área construída e depois revender com lucro para possibilitar o financiamento da criação de um bairro remodelado. O plano da EMURB não passaria, nessa visão, do exercício pelo Estado de uma atividade imobiliária sob o manto do domínio eminente, o que a ele não pareceria de forma alguma justificável frente ao sistema constitucional então vigente. Ou, em suas palavras:

"A questão fundamental, na hipótese, é a de se saber se, em face da Constituição Federal e das leis que declaram os casos de necessidade e utilidade públicas e de interesse social, pode o Poder Público desapropriar áreas para construir prédios destinados à alienação para atender os fins previstos no caso presente." 122

O Ministro faz essa primeira colocação para, em seguida, verbalizar o critério central que reputa necessário a qualquer revenda de bens desapropriados pelo poder público:

"Essa venda [de bens expropriados], no entanto, tem de ser indispensável para a consecução da finalidade para a qual se destina a desapropriação: necessidade ou utilidade pública, ou interesse social."

Com o critério devidamente balizado, o Ministro expõe a sua decisão:

"A presente desapropriação, no que diz respeito à expropriação de área para a construção de edifícios comerciais e residenciais para venda a particulares - que é o aspecto nela impugnado - se enquadra em alguma das letras invocadas no art. $5^{\circ}$ do Decreto-Lei $n^{o}$

\footnotetext{
${ }^{121}$ Voto do Ministro Moreira Alves no RE 82.300. Citado em DALLARI, op. Cit., p. 153.

${ }^{122}$ Voto do Ministro Moreira Alves no RE 82.300. Citado em DALLARI, op. Cit., p. 155.
} 
3.365/41, por ser ínsita aos casos aí previstos a imprescindibilidade de construções dessa natureza?

A meu ver, impõe-se a resposta negativa."

O que não se afirma é que parte relevante da controvérsia possui uma origem inquestionável - mas que não poderá ser de todo aqui explicitada - uma disputa em torno do que recai dentro do escopo de utilidade pública e o que estaria fora e seria, consequentemente, reputado ilícito. Uma disputa em termos concretos daquilo que Hart chamou de open texture of law:

“This imparts to all rules a fringe of vagueness or 'open texture', and this may affect the rule of recognition specifying the ultimate criteria used in the identification of the law as much as particular statute."124

Definir o que converge ou não com a utilidade pública e constitui, por isso, parte integrante do interesse público, recai em âmbito próprio a texturas abertas. A concretização do interesse público necessitaria de uma análise e decisão em torno de ser, ou não, a desapropriação para revenda, da forma como proposta pela EMURB, um fim público. Nesse ponto, inquestionavelmente, as opiniões no STF divergiram, embora os Ministros tivessem os mesmos dados fáticos e a mesma legislação diante de si.

A despeito desse traço próprio ínsito aos sistemas normativos - i.e., a variabilidade de conteúdos das normas - o Ministro Moreira Alves segue em seu esforço de especificação daquilo que entende ser a disciplina legal das desapropriações. Nesse esforço, estabelece mais uma distinção de extrema utilidade, novamente valendo-se de uma fonte doutrinária. Trata-se dos diferentes critérios aplicáveis às desapropriações para criação de acervo imobiliário dominical do Estado e aqueles aplicáveis a desapropriações para cumprimento de uma utilidade pública. Segundo Moreira Alves:

"A utilidade pública pressupõe que a desapropriação se faça com a finalidade de ser útil a todos, ao público em geral.",125

Os interesses imobiliários do Estado quando não relacionados a uma função pública legítima não gozariam das prerrogativas inerentes ao domínio comum ou às necessidades da fruição coletiva de um serviço ou utilidade pública, tomada essa numa conceituação material e

\footnotetext{
${ }^{123}$ Voto do Ministro Moreira Alves no RE 82.300. Citado em DALLARI, op. Cit., p. 157.

${ }^{124}$ HART, H. L. A. The Concept of Law. Oxford: Oxford University Press, 2nd Edition, 1997, p. 123.

${ }^{125}$ Voto do Ministro Moreira Alves no RE 82.300. Citado em DALLARI, op. Cit., p. 157.
} 
não apenas formal. Não seria, nesse sentido, possível equiparar o interesse do Estado como ente, e de seus representantes, ao interesse público em si. Em termos mais precisos:

"É preciso que não se confunda necessidade pública, ou utilidade pública, com o ser necessário ou útil ao patrimônio dito dominical (Código Civil [1916] art. 66, III) do Estado. Não há desapropriação porque o bem convenha à Fazenda Pública, porque aí trata de interesse privado da União, do Estado-membro, ou do Município (W. von Rohland, Zur Theorie und Praxis, 15; C. F. Grünhut, Das Enteignungsrecht, 79), como se o Estado precisa do prédio para instalar a administração dos seus bens dominicais, ou com a área exproprianda, conseguiria maior preço por metro quadrado ou de frente." 126

Posto de outra forma, a utilidade pública não existiria pela mera relação patrimonial do Estado com o bem, mas por sua funcionalização com vistas à criação de uma utilidade pública, ainda que o conteúdo desta ideia esteja em constante aprimoramento e não tenha um conteúdo semântico determinado a priori. Mesmo ao se admitir essa flexibilidade de carga semântica é possível, ainda assim, estabelecer uma restrição, por exemplo, a de que utilidade pública não equivale à propriedade estatal ou àquilo que o Estado quer incluir em seu acervo patrimonial.

Mas não é apenas por essa via que o Ministro Moreira Alves chega à sua conclusão acerca da ilicitude do comportamento do Estado, mas por meio de um raciocínio de matiz liberal. A premissa é que o direito brasileiro consagra o direito à propriedade, restringindo-o nas hipóteses lícitas de desapropriação. Ao não subsumir o procedimento adotado em São Paulo a nenhuma das hipóteses, tem-se que remanesce o direito à propriedade e não a sua perda em favor do interesse público. Em suas palavras e síntese conclusiva:

"É esse, a meu ver, o nosso sistema jurídico que não admite, em detrimento da propriedade privada, que a desapropriação tenha por fim a construção de prédios que não visem à utilidade pública, ou não sejam casa populares para atender o interesse social, mas que se destinem a manter atuais residentes, ou a propiciar ao Poder Público esquemas econômico-financeiros para financiamento de obras públicas. $" 127$

Não existiria, pois, um fundamento de expropriação calcado em interesse público abstrato sem correspondente nas hipóteses legais da legislação. Consequentemente, não se podendo enquadrar em uma das hipóteses legais de desapropriação, prevalecerá a propriedade

\footnotetext{
${ }^{126}$ PONTES DE MIRANDA, Francisco Cavalcanti. Tratado de Direito Privado. Rio de Janeiro: Borsoi, v. XIV, p. 188.

${ }^{127}$ Voto do Ministro Moreira Alves no RE 82.300. Citado em DALLARI, op. Cit., p. 161.
} 
e não a sua perda. Visto de maneira abstrata, o posicionamento do Ministro consagra uma separação forte entre público e privado, tendo-se em vista que o direito à propriedade - o domínio do privado - apenas poderá ser restringido nas hipóteses legais. Por essa razão, se não se reconhece a ocorrência de uma das hipóteses de restrição ao privado o que prevalecerá não será o público e a consequente incorporação do bem ao seu domínio, mas sim a manutenção do domínio privado.

Após a exposição do Ministro Moreira Alves e sua opinião contrária ao projeto da Prefeitura de São Paulo, tomará a palavra o Ministro Leitão de Abreu para, na mesma sessão, realizar uma defesa bem fundamentada da desapropriação. É interessante analisar de forma breve a trajetória do Ministro para, possivelmente, entender-lhe a posição. O Ministro João Leitão de Abreu foi professor de Direito Administrativo na Universidade Federal do Rio Grande do Sul e, mais importante, participou como Chefe da Casa Civil no Estado do Rio Grande do Sul no Governo Ildo Menghetti. Após requerer seu desligamento do Supremo, tornou-se Ministro Chefe da Casa Civil do Governo João Baptista Figueiredo (1981-85).

Embora tais traços biográficos não sejam decisivos para o conteúdo de sua decisão, é possível que sua formação e história de vida tenha, em parte, influenciado sua visão mais pragmática e aberta a tomar decisões que resguardem uma "policy". Em sua opinião, os conceitos de propriedade privada e utilidade pública haveriam de ser reinterpretados diante de mudanças nas situações de fato. Em uma passagem um tanto longa, mas que vale citar, o Ministro expõe sua visão do assunto:

"É natural que numa sociedade a braços com problemas dessa ordem, problemas inéditos e dramáticos, antigos conceitos jurídicos, elaborados sob realidade social diferente, se sujeitem a revisão, notadamente no que concerne aos direitos de propriedade. Embora esta guarde como traço característico a faculdade de excluir, atribuída ao seu titular, em contraste como observa Ruy Cirne Lima, com a pretensão a não ser excluído, assegurada ao utente, no que diz respeito aos bens de uso comum, o certo é que o direito de propriedade sofre, quanto à sua feição despótica e agressiva, erosão cada vez mais acentuada diante das injunções do interesse público ou, melhor dito, do interesse social."128

\footnotetext{
${ }^{128}$ Voto do Ministro Leitão de Abreu no RE 82.300. Citado em DALLARI, op. Cit., pp. 165-6.
} 
O voto do Ministro possui traços de erudição distinta em comparação aos dos outros julgadores, na medida em que Leitão de Abreu recorre a Le Corbusier e Lewis Mumford ${ }^{129}$ para expor sua concepção sobre o processo de metropolitanização e suas consequências sobre a cidade e sua população. Na toada de seu argumento, o advento da cidade então contemporânea (1973) operaria mudanças na configuração do direito, fazendo com que a aplicação de conceitos normativos se alterasse ao terem de ser utilizados diante de novos contextos que não haviam sido previstos em sua gênese. Segundo ele, seria esse o caso do conceito de direito de propriedade quando aplicado de modo não reconfigurado para a desapropriação urbanística do metrô.

A visão de que mudanças fáticas geram alterações em conceitos jurídicas é sujeita a contestações, como se pôde constatar dos votos precedentes, que não a acatam. É o próprio Leitão de Abreu que afirma em favor de uma interpretação evolutiva dos conceitos jurídicos: “(...) o conceito de uso público é indeterminado ou indefinido, dando lugar a diversidade de interpretações." 130

A despeito de haver outros pontos passíveis de destaque em seu argumento, o foco do voto proferido pelo Ministro é o de que a concepção de utilidade pública se altera, não é estática. Fixada essa premissa, ele observa as mudanças nas cidades e as necessidades que estas geram na organização e disciplina do espaço. Se, anteriormente, as competências da municipalidade incluíam a abertura de viário, criação de instituições de ensino, lazer e saúde, as transformações urbanas passam a requerer também intervenções na ordenação territorial. Frente a isso, o executivo municipal poderá ter que manejar o instrumento expropriatório, não somente para adicionar bens a seu acervo imobiliário, mas igualmente para readequar o espaço na cidade. Seria essa, sinteticamente, a utilidade pública perseguida com a desapropriação, uma utilidade que não se consubstancia em um bem público, mas que instrumentaliza a passagem fugaz do bem pelo domínio público a fim de possibilitar que outros privados lhe deem a destinação socialmente adequada.

Se tal premissa se confirma, então nada mais em desacordo com essa utilidade que a manutenção dos bens sob titularidade do município. De acordo com essa visão, a venda não seria contrária à utilidade pública declarada, mas antes o último elo para a sua concretização

\footnotetext{
129 Respectivamente LE CORBUSIER. La Ciudad del Futuro. Buenos Aires: Ediciones Infinito, 1962 e MUMFORD, Lewis. The Urban Prospect. Londres: Harcourt, Brace \& World, 1968.

${ }^{130}$ Voto do Ministro Leitão de Abreu no RE 82.300. Citado em DALLARI, op. Cit., pp. 169.
} 
que, afinal, foi, desde o início, a reordenação do espaço na metrópole e não a criação de bens públicos, estejam eles afetados ou não a um serviço público.

Por essa linha de raciocínio, em suma, negou Leitão de Abreu razão ao recorrente ao não conhecer do recurso levado ao tribunal. Para ele, a noção de público e privado, a noção de propriedade e sua função social, eram alteradas com a emergência do fenômeno urbano. A propriedade como a prerrogativa de excluir qualquer terceiro poderia ser funcional em um ambiente menos socializado, na grande metrópole, contudo, essas relações de interdependência intensificavam-se. Diante desse quadro, nada mais que o Estado atuasse para darlhe destinação conforme a sua função social. Nessa linha, seria a desapropriação uma das formas de adequar a propriedade à função na cidade.

Sucedendo o voto do Ministro Leitão de Abreu, pronunciou-se o Ministro João Baptista Cordeiro Guerra de modo breve e direto. Uma de suas frases iniciais explicita o tom de seu voto e de seu pensamento sobre o assunto:

"Sou um homem que acredita na iniciativa privada, na propriedade. Acho que a propriedade é um instrumento e uma garantia da liberdade. Onde a propriedade privada não é respeitada, desaparecem as liberdades e os direitos fundamentais do homem."

Seu argumento segue na direção segundo a qual a substituição do interesse particular e da propriedade particular por um interesse social não gera benefícios propriamente sociais. A aparente contradição se resolve em seu posicionamento pela colocação de que a garantia de direitos fundamentais, a propriedade e a liberdade, constituem o fundamento de uma ordem política justa. Ao se negar tais direitos em nome da resolução de problemas sociais, como os de habitação, então o que há não é simplesmente o desrespeito à propriedade privada, mas sim a destruição de uma ordem pelo desrespeito a um direito fundante da sociedade. Em outros termos, a derrogação da propriedade para além dos estritos casos legais não serviria ao propósito do interesse público, mas sim atingiria um dos alicerces da ordem social como a entendia o Ministro Cordeiro Guerra, um "homem que acredita na iniciativa privada." Isso porque o interesse de um indivíduo, de fato, não constituiria o interesse coletivo. Todavia, era de interesse coletivo que o Estado não desrespeitasse os direitos individuais. Por acreditar que a Prefeitura de São Paulo valia-se de um pretenso interesse coletivo para atingir direitos e

\footnotetext{
${ }^{131}$ Voto do Ministro Cordeiro Guerra no RE 82.300. Citado em DALLARI, op. Cit., pp. 177.
} 
garantias individuais, concedeu o Ministro provimento ao recurso e, consequentemente, a segurança aos impetrantes.

Em sessão do dia 16 de dezembro de 1977, voltou ao Plenário do Supremo a discussão da desapropriação do metrô de Santana, oportunidade em que votou o Ministro Bilac Pinto. Voto também sucinto, ao longo do qual ocorreu um pequeno debate oral envolvendo os Ministros Bilac Pinto, Rodrigues Alckmin e Moreira Alves. Em linhas gerais, os dois primeiros, favoráveis à desapropriação, ressaltaram o aspecto instrumental ao interesse público tanto da desapropriação quanto da revenda de seu produto. Por outro lado, o Ministro Moreira Alves enfatizou o aspecto do lucro na revenda, o que equivaleria ao exercício pelo Estado de uma atividade muito próxima à indústria imobiliária. A isso, de forma ligeiramente irônica, retorquiu o Ministro Bilac Pinto ser a cidade da sede do Tribunal, Brasília, o maior exemplo justamente do que ora condenava o Ministro Moreira Alves. Ali o Estado desapropriou toda uma área e, posteriormente, revendeu o produto da desapropriação aos particulares, com certeza a preços que superaram os valores pagos a título de indenização. Desse modo sumário, finaliza seu voto para acompanhar o relator, negar o recurso e, pois, permitir que a Prefeitura de São Paulo siga com seus planos de reurbanização.

Dando continuidade ao julgamento pelo Supremo, votaram os Ministros Djaci Falcão e Antonio Neder pela ilegalidade do procedimento adotado pela Prefeitura de São Paulo. Pouco eles aduzem em termos de argumentos, porém pontuam fortemente ser a atividade imobiliária e o financiamento de obras públicas por meio da valorização de imóveis, formas inidôneas de sustentar o investimento dos municípios em melhorias urbanas. Ressaltam que, a depender do regime de proteção à propriedade que o STF impusesse, poderia isso refletir nos ânimos dos executivos municipais. Como pontua o Ministro Antonio Neder:

"Se o negócio imobiliário [desapropriação com posterior revenda] for aprovado pelo $S T F$, nossos prefeitos interioranos ficarão armados de um terrível instrumento de perseguição político-partidária, meio abusivo tão perigoso quanto negar-se o direito de desapropriar para o interesse público; e, ainda mais, os desapropriamentos (sic) para urbanizar mediante incorporação imobiliária irão proliferar em verdadeira orgia oficial."132

$\mathrm{Ou}$ seja, uma das preocupações dos julgadores possuía viés claramente consequencialista ao pensar a decisão como um parâmetro para o comportamento futuro e para

\footnotetext{
${ }^{132}$ Voto do Ministro Antonio Neder no RE 82.300. Citado em DALLARI, op. Cit., pp. 180.
} 
impor limitações aos prefeitos que, porventura, quisessem intentar restringir os direitos de propriedade dos munícipes.

Contrastando esse posicionamento consequencialismo para a tutela da propriedade, vêm os Ministros Carlos Thompson Flores e Xavier de Albuquerque a conduzir o julgamento a um impasse, pois, ao proferirem seus votos, passaria a haver cinco votos favoráveis e cinco contrários à desapropriação. Para além do empate, nas palavras do Ministro Thompson Flores, tratava-se de extrair as consequências adequadas do contexto que se tinha diante de si. Inquestionavelmente, o regime de socialização e funcionalização da propriedade que haveria de ser imposto aos habitantes de uma metrópole eram distintos daqueles a que eram submetidos os moradores de pequenas comunidades semi-rurais. Em suas palavras:

"O que não posso aceitar, com a máxima vênia, é que se obste, se impeça, ou se prejudique a execução do plano de reurbanização de uma das cidades de maior densidade populacional da América, e que precisa acompanhar o progresso, em bem de sua própria população, sob pretexto invocado, deslembrado até da função social da propriedade, a que se refere o art. 160, III, da Constituição [na forma da Emenda 1/1969]."133

De resto, inquestionavelmente, também o direito sofria os efeitos do tornar-se metrópole. Há outras pesquisas que buscam compreender como a aglomeração e aumento da interação em comunidades afetam as concepções de mundo e outros produtos culturais do humano. No caso de São Paulo, e de sua poesia, vale mencionar o estudo do Professor Nicolau Sevcenko sobre os anos 1920 e a aceleração do cotidiano e da vida cultural. As danças, os esportes, as letras, em graus diversos, foram afetados pelo efeito transformador da realidade metropolitana que se desenhava.

"A emergência das grandes metrópoles e seu vórtice de efeitos desorientadores, suas múltiplas faces incongruentes, seus ritmos desconexos, sua escala extrahumana e seu tempo e espaço fragmentário, sua concentração de tensões, dissiparam as bases de uma cultura de referências estáveis e contínuas."134

Diante dessa circunstância meramente esboçada, e com o aprofundamento do processo no século XX, não parece crível pensar que o direito passaria incólume. Possivelmente por esse motivo, as divergências recrudesceram no Supremo e não indicavam uma solução simples

\footnotetext{
${ }^{133}$ Voto do Ministro Carlos Thompson Flores no RE 82.300. Citado em DALLARI, op. Cit., pp. 187.

${ }^{134}$ SEVCENKO, Nicolau. Orfeu Extático na Metrópole: São Paulo sociedade e cultura nos frementes anos 20. São Paulo: Cia. Das Letras, 1992, p. 32.
} 
e consensual. Com efeito, a tensão entre tutela da propriedade privada e uma interpretação evolutiva do conceito de utilidade pública apenas se resolveria definitivamente em 12 de abril de 1978 com o voto do Ministro Soares Muñoz. Pendeu o rumo histórico naquele momento para a ampliação do conceito de interesse público e, consequentemente, para a aceitação da legalidade do plano urbanístico da cidade de São Paulo. Na apresentação de seu voto, o Ministro fez uma distinção entre revenda de bens expropriados como meio e revenda como fim. Na hipótese de sua análise, a desapropriação e posterior revenda constituía caso de meio para o atingimento de um fim público relevante, a reordenação territorial para a chegada do metropolitano à região de Santana. Em desfavor, portanto, do privado e consagrando a atinência ao interesse público de que haveria de gozar o plano. Com esse raciocínio final, a despeito das divergências em outros pontos, a desapropriação, enfim, prevaleceu e o plano do Município para remodelar o bairro não foi interrompido por ordem do Supremo.

Para além das certamente relevantes discussões dogmáticas, cabe pontuar que, ao se manifestarem, os Ministros não expuseram apenas suas concepções jurídicas sobre desapropriações. Há, como bem se nota pelo voto do Ministro Cordeiro Guerra, em conjunto com a argumentação jurídico-dogmática, a ela imbricada, uma concepção de delimitação entre o público e o privado. Ao serem chamados a se posicionar, os Ministros, voluntariamente ou não, expuseram uma série de concepções que permeavam a sociedade brasileira e expuseram, sem dúvida, alterações em comparação ao que se viu no caso anterior, o do Rio Pinheiros.

Inegavelmente, houve um deslocamento em direção à publicidade, à prevalência do interesse público. No entanto, da mesma forma que antes, a representação séria do cotidiano permanece esmorecida. Provavelmente porque a forma de representação jurídica da realidade exclua esse âmbito ao categorizar as manifestações fáticas em abstrações que pouco guardam de sua base fenomênica. O conflito juridicamente exposto se constitui como uma série de abstrações, que não constitui um defeito de representação, mas sim um traço inerente à lente e à forma jurídica.

Ver nessa representação uma insuficiência, e por isso reprová-la, é não compreender os mecanismos de representação, necessariamente, seletivos, por captarem aquilo que a forma permite, porquanto uma representação total seria, em verdade, o antípoda da representação. $\mathrm{O}$ interessante é extrair da forma aquilo que ela transmite, o que também se aplica à forma jurídica, que igualmente possui os seus limites da representação. 
Em síntese, pois, o caso do metrô de Santana, à sua maneira, registra uma visão sobre o público e o privado na sociedade brasileira, bem como reflete em parte as suas divisões e divergências na conceituação dessas duas esferas. Inquestionavelmente, trata-se de uma visão parcial, o que é característico a todas as formas de representação/exposição.

A impressão da leitura seguida dos dois casos - Pinheiros e Santana - é justamente que houve um amadurecimento do lugar do público nas relações jurídicas. O fato de ter sido enunciado como uma questão que envolveria o direito público e a sujeição do particular representa, em si, um desdobramento a se notar. A hipótese aventada seria a de que o direito, ao refletir a realidade, a acompanharia em alguns dos seus deslocamentos. Se o real cotidiano foi negligenciado também em Santana, em compensação a forma de exposição desses dois âmbitos que elegemos acompanhar se tornou mais séria. De caracterização mais marcada, a discussão sobre o que é público e aquilo que é privado transpareceu de forma mais vigorosa e deixou para trás um hábito de ler dogmaticamente os conflitos entre o indivíduo e o Estado pelo viés do direito privado. Esse, certamente, um bom desdobramento dos tempos que separaram as duas desapropriações. 


\section{Epílogo}

O intuito do que veio acima foi, em grande medida, o teste de uma hipótese, a saber, a de que o direito, como registro e forma, absorve elementos externos e os reorganiza a seu modo. Essa sugestão adveio de uma relação com algumas vertentes da teoria literária e da constante tentativa que esta faz de extrair traços históricos dos registros literários. Da mesma forma que a literatura seria uma forma de mediação da história e da sociedade, também o direito, à sua maneira, parecia sê-lo. Não se tratava de negar a forma por excelência do direito, a dogmática, mas observar como a dogmática operava na produção de leituras do real.

Para isso, buscou-se contrastar dois momentos distintos da elaboração dogmática, colocando-os lado a lado. A escolha da desapropriação foi sintomática e relevante por ser uma fração do direito extremamente suscetível em refletir momentos históricos e políticos e por gerar fortes reações e conflitos diante dos tribunais.

As noções de domínio público e de interesse público nas desapropriações foram sendo construídas e delimitadas ao longo do século XX. Buscar nas decisões judiciais uma direção unívoca de evolução seria tão ingênuo quanto improvável, pois seria seguir os passos de um movimento provavelmente incerto e que seguiu de modo não retilíneo.

Como a sugestão desse trabalho foi a de tentar seguir os passos de um originalmente jurista que pendeu para a filologia, Auerbach, nada mais à altura do que buscar um arremate com uma tentativa de interpretação de decisão judicial que teria buscado essa mediação do cotidiano no registro jurídico, ajustar-se a ele, de forma séria, quebrando-lhe de alguma forma a moldura ${ }^{135}$.

Essa ideia de realismo e exposição do cotidiano pode ser identificada na síntese que Waizbort faz de Auerbach e sua empreitada em Mimesis:

"Um determinado tipo ou modalidade de realismo depende sempre dos limites da consciência histórica, que dizem respeito à capacidade de percepção das forças históricas, $e$

\footnotetext{
${ }^{135}$ A metáfora da quebra da moldura é recorrente em Auerbach e quer significar, no mais das vezes, algum movimento de apreensão do real que se liberta de estruturas narrativas prévias para aprofundar ou recriar formas de exposição. Veja-se, por exemplo, a passagem da quebra criada por ele para caracterizar a superação da moldura cristã na literatura de Dante: "A obra de Dante tornou realidade a essência cristã-figural do homem e a destruiu na mesma realização; a poderosa moldura rompeu-se pela supremacia dos quadros que envolvia. As grosseiras desordens resultantes dos mistérios, na Idade Média posterior, não são nem longinquamente tão perigosas para a manutenção de uma interpretação figural-cristã dos acontecimentos como o estilo elevado de um poeta, no qual os homens se veem e se reconhecem a si próprios." AUERBACH, Erich. Mimesis. op. cit., p. 175.
} 
esta depende finalmente, por assim dizer, do grau de reconhecimento da dramaticidade e problematicidade da vida cotidiana. Quanto maior o reconhecimento, maior a consciência histórica, e correspondentemente mais profundo, sério e problemático o realismo."136

À sua maneira, a Apelação Cível 212.726-1/8 da Comarca de São Paulo, julgada pelo Tribunal de Justiça do Estado, buscou reter o cotidiano em sua representação. Tratava-se então de uma reintegração de posse movida por antigos proprietários de imóveis que haviam sido invadidos. Reivindicada a coisa, o juiz de primeiro grau deferiu o pedido aos autoresproprietários, mas é o passo seguinte que nos interessa, a decisão do desembargador José Osório de 1994 na apelação. Ao iniciar a sua argumentação nos autos, a redação do decisor toma caminhos heterodoxos, como na passagem: "A realidade urbana é outra. A Favela já tem vida própria, está, repita-se, dotada de equipamentos urbanos."137. Certamente, uma formulação pouco corrente para se julgar uma ação fundada em direitos reais.

Mas bem, o que vale comentário é justamente essa passagem, o desembargador passa a descrever a favela, seus hábitos, para culminar na descaracterização jurídica do pedido pela emergência daquela realidade, que o direito não abarcaria e, por isso, não estaria apto a alterar. Pouco antes de fazer referência à realidade, escreve ele: "Os lotes de terreno reivindicados e o próprio loteamento não passam, há muito tempo, de mera abstração jurídica". E depois arremata, "A realidade concreta prepondera sobre a 'pseudo-realidade jurídicocartorária" ${ }^{\prime 138}$.

Em um só movimento, a decisão busca afirmar a prevalência do real sobre o jurídico, mas para isso busca captar juridicamente, refundar, em alguma medida, a moldura do direito que olha para um assentamento informal na cidade. Essa captação da realidade será essencial para o argumento, ou seja, é pela afirmação da superação do modelo e da moldura que o desembargador busca fundamentos para seu decisum. Ao negar a aplicabilidade do direito de propriedade, ele, a seu modo, reedita um argumento de alteração de conteúdo e aplicabilidade de regras diante de drásticas mudanças fáticas. Assim já fizera o Ministro Leitão de Abreu no RE 82.300. Mas no Supremo o argumento da realidade estava distante, ainda não se referia a algo tão concreto e cru como a "favela do Pullman", não tinha essa necessidade premente de

\footnotetext{
${ }^{136}$ WAIZBORT, Leopoldo. A Passagem do três ao um: crítica literária, sociologia, filologia. São Paulo: Cosac \& Naify, 2007, 309.

${ }^{137}$ Revista dos Tribunais, v. 723, 1996, p.205-6.

${ }^{138}$ Respectivamente, op. cit., pp. 205 e 206.
} 
decidir com base no real quotidiano, mas apenas promover a readequação do lugar da propriedade em um contexto urbano. Nessa apelação cível, ao contrário, será preciso não apenas readequar a noção de propriedade às mudanças nas condições históricas, mas negá-la. Não porque o direito à propriedade desapareceu, mas porque seu objeto real pereceu.

Em suma, ainda que do ponto de vista teórico-metodológico possa se reprovar as colocações feitas no acórdão, pareceu-nos o mais condigno terminar com essa pequena menção a esse documento. Pois ele nos pareceu a forma mais forte de afirmação do real na jurisprudência que conhecemos, pareceu uma tentativa, ainda que canhestra, em promover uma representação do quotidiano a despeito e para além dos limites das estruturas jurídicas.

A provar que elas não se superam tão facilmente, basta ver a reapreciação ao final do voto. Embora realidade em estado bruto, a favela que erode o objeto da propriedade e anula o jus reivindicandi estaria, ao fim e ao cabo, presa no princípio da função social da propriedade $^{139}$. Quando menos se espera, aí o jurídico retorna com a sua categorização do mundo.

${ }^{139}$ Op. cit., p. 208. 


\section{Bibliografia}

ACKERMAN, Bruce A. Private Property and the Constitution. New Haven: Yale University Press, 1977.

ARRUDA, João. A desapropriação da São Paulo Northern. Rio de Janeiro: Jornal do Comércio, 1920.

AUERBACH, Erich. Literary Language and Its Public in Late Latin Antiquity and in the Middle Ages. New York: Pantheon Books, 1965. Mimesis: A representação da realidade na literatura ocidental. São

Paulo: Perspectiva, $4^{\mathrm{a}}$ Edição, 2001. Ensaios de Literatura Ocidental. São Paulo: Duas Cidade/Ed. 34, 2007.

BALZAC, Honoré de. Le Père Goriot. Paris: Pocket, 2001.

BINENBOJM, Gustavo. Uma Teoria do Direito Administrativo: Direitos Fundamentais, democracia e constitucionalização. Rio de Janeiro: Renovar, $2^{\text {a }}$ Edição, 2008.

CANDIDO, Antonio. Formação da literatura brasileira: Momentos decisivos 1750-1880. Rio de Janeiro: Ouro sobre Azul, 2009. . A Educação pela Noite. Rio de Janeiro: Ouro sobre Azul, 2006. . Literatura e Sociedade: Estudos de Teoria e História Literária. Rio de Janeiro: Ouro sobre Azul, 10ª Ed., 2008. O discurso e a cidade. Rio de Janeiro: Ouro sobre Azul, $4^{\mathrm{a}}$ Ed., 2010.

CARVAlHO, José Murilo. A Construção da Ordem: A elite política imperial/Teatro das Sombras: A política imperial. Rio de Janeiro: Civilização Brasileira, 2003.

CASTRO NUNES, José. "Desapropriação por Zona. Retrocessão" in Revista de Direito Público, v. 7, 1969.

CAVALCANTI, Themístocles B. "Desapropriação por Zona. Retrocessão" in Revista de Direito Público, v. 7, 1969.

CRUZ, João Claudino de Oliveira. Da desapropriação em face do nosso direito constitucional. Rio de Janeiro: Coelho Branco, 1937.

DALLARI, Adilson de Abreu. Desapropriação para fins urbanísticos. Rio de Janeiro: Editora Forense, 1981. 
DWORKIN, Ronald. Taking Rights Seriously. Cambridge, Mass.: Harvard University Press, 1978.

ELLICKSON, Robert. "Property in land“, Yale Law Journal, v. 102, 1993, pp. 1315-1400.

EMURB. A Reurbanização de Santana e Jabaquara: Memorial para o julgamento de Mandados de Segurança. São Paulo, 1973.

EPSTEIN, Richard A. Takings: Private property and the Power of eminent domain. Cambridge, Mass.: Harvard University Press, 1985.

FOUCAULT, Michel. "La Vérité et les Formes Juridiques” in Dits et Écrits I, 1954-1975. Paris: Quarto-Gallimard, 2001.

FUSTEL DE COULANGES, Numa Denis. “L'Analyse des Textes Historiques” in Revue des Questions Historiques, 21ere Année, Tome 41 ${ }^{\mathrm{e}}, 1887$.

GINZBURG, Carlo. O queijo e os vermes: $O$ cotidiano e as ideias de um moleiro perseguido pela Inquisição. São Paulo: Cia. das Letras, 2006.

HART, H. L. A. The Concept of Law. Oxford: Oxford University Press, 2nd Edition, 1997.

HEINZELMANN, Martin. Gregory of Tours: History and Society in the Sixth Century. Cambridge: Cambridge University Press, 2001.

LEITE, Solidonio. Desapropriação por utilidade pública. Rio de Janeiro: J.Leite, 1928.

LESSA, Thomaz. Caso de desapropriação sem utilidade pública. São Paulo: São Paulo Editora, 1933.

MCDOWALL, Duncan. Light: A História da Empresa que modernizou o Brasil. São Paulo: Ediouro, 2008.

MICHELMAN, Frank I. "Property, Utility and Fairness", Harvard Law Review, v. 80, n. 6, 1967. . “Takings, 1987”, Columbia Law Review, v. 88, 1988, pp. 1600-22.

MONOD, Gabriel. "Les Aventures de Sichaire" in Revue Historique, 11eme Année, Tome $31^{\mathrm{e}}, 1886$.

“Lettre de M. G. Monod en réponse à l'article de M. Fustel de Coulanges intitulé 'De l'analyse des textes historiques."' Revue des questions historiques, Tome 41, 1887.

RÁO, Vicente. "Desapropriação por Zona. Retrocessão" in Revista de Direito Público, v. 7, 1969. 
ROCHA, João Cezar de Castro. Literatura e Cordialidade: O público e o privado na cultura brasileira. Rio de Janeiro: Ed. UERJ, 1998.

ROLNIK, Raquel. A Cidade e a Lei: Legislação, política urbana e territórios na cidade de São Paulo. São Paulo: Studio Nobel, 1997.

ROSE-ACKERMAN, Susan. "Against Ad Hocery: A comment on Michelman", Columbia Law Review, v. 88, 1988, pp. 1697-1711.

ROSENFELD, Anatol et al. A personagem de ficção. São Paulo: Perspectiva, 1961.

SAMPAIO, João. Sobre uma desapropriação da Light e Power. São Paulo: Revista dos Tribunais, 1936.

SARMENTO, Daniel (org.). Interesses Públicos versus Interesses Privados: Desconstruindo o Princípio de Supremacia do Interesse Público. Rio de Janeiro: Lumen Juris, 2007.

SCHWARZ, Roberto. Que horas são? Ensaios. São Paulo: Cia. das Letras, 1987. Ao vencedor as batatas. Forma literária e processo social nos inícios do romance brasileiro. São Paulo: Duas Cidades; Ed. 34, 2000. Um mestre na periferia do capitalismo: Machado de Assis. São Paulo:

Ed. 34, 2000.

SEABRA, Odette C. L. Os Meandros dos Rios nos Meandros do Poder: Tietê e Pinheiros valorização dos rios e das várzeas na cidade de São Paulo. São Paulo: Departamento de Geografia da Faculdade de Filosofia, Letras e Ciências Humanas da Universidade de São Paulo, 1987 (Tese de Doutorado).

SEABRA FAGUNDES, Miguel. Da desapropriação no direito brasileiro. Rio de Janeiro: Freitas Bastos, 1942.

SEVCENKO, Nicolau. Orfeu extático na metrópole: São Paulo sociedade e cultura nos frementes anos 20. São Paulo: Cia. das Letras, 1992.

. Literatura como missão: Tensão social e criação cultural na primeira república. São Paulo: Cia. das Letras, $2^{\text {a }}$ Edição, 2003. A Revolta da Vacina: Mentes Insanas em Corpos Rebeldes. São Paulo: Cosac \& Naify, 2010.

SODRÉ, Eurico. Desapropriação por necessidade ou utilidade pública. São Paulo: Saraiva, 1928.

TOMASETTI JR., Alcies. "Comentário" in Revista dos Tribunais, v. 723, 1996. 
WHITAKER, Firmino Antonio da Silva. Desapropriação: Estado de São Paulo. São Paulo: O Estado de São Paulo, 1925.

WAIZBORT, Leopoldo. "Erich Auerbach sóciologo" in Tempo Social, v. 16, n. 1, 2004.

A Passagem do três ao um: crítica literária, sociologia, filologia. São

Paulo: Cosac \& Naify, 2007. 